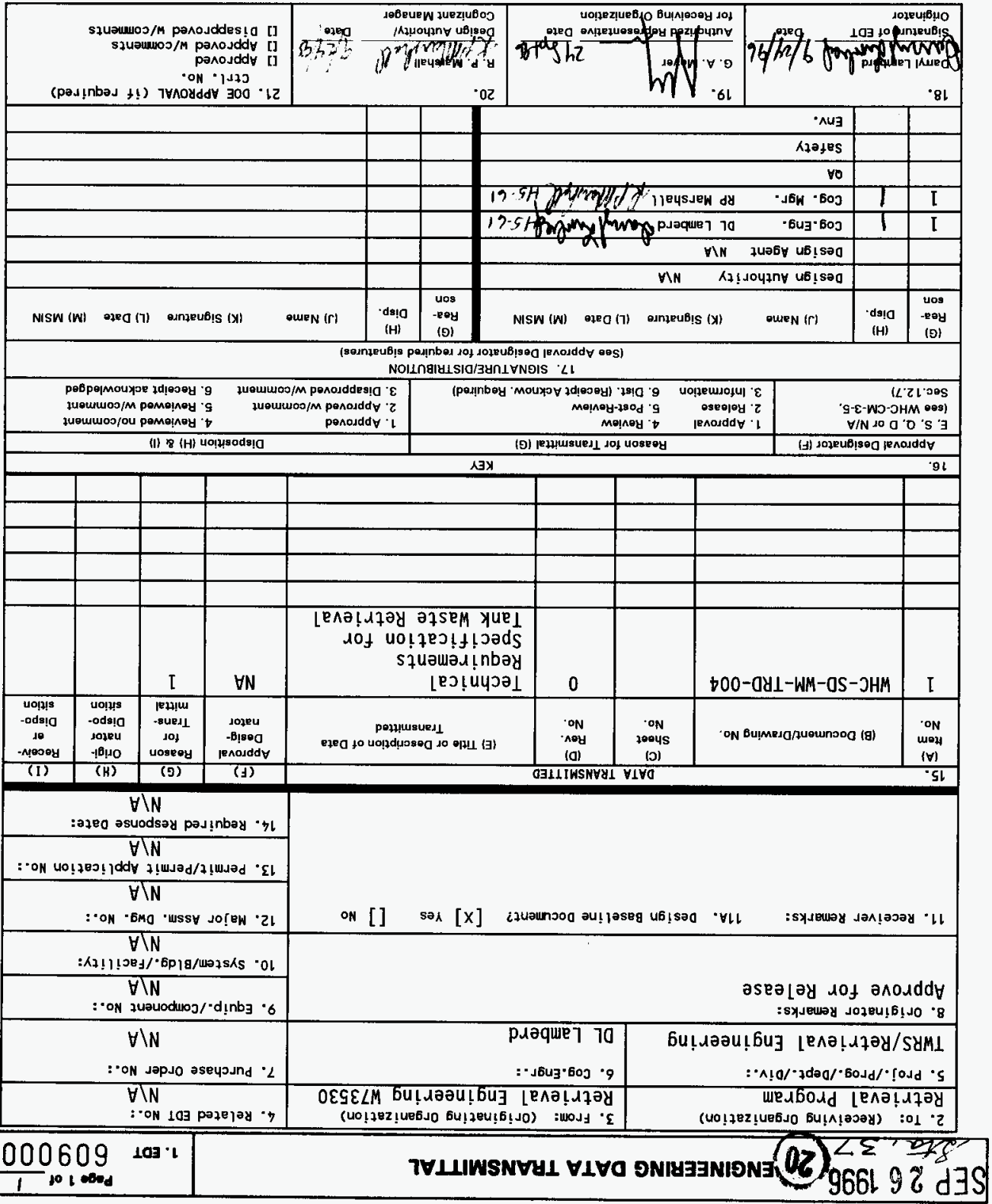




\title{
Technical Requirements Specification for Tank Waste Retrieval
}

\author{
Darryl Lamberd
}

Westinghouse Hanford Company, Richland, WA 99352

U.S. Department of Energy Contract DE-AC06-87RL10930

$\begin{array}{llll}\text { EDT/ECN: } & 609000 & \text { UC: } & 2030 \\ \text { Org Code: } & 73530 & \text { Charge Code: } & 02074 \\ \text { B\&R Code: } & \text { EW3130010 } & \text { Total Pages: } & 127\end{array}$

Key Words: Requirements, Systems Engineering, Technical, Specification

Abstract: This document provides the technical requirements specification for the retrieval of waste from the underground storage tanks at the Hanford site. The waste retrieval system is a major architecture element of the Tank Waste Remediation System (TWRS) to mobilize sludge and solids contained in underground storage tanks, and transport the waste from the storage system to the waste processing system for treatment. Included in this specification are the overall technical system requirements for Single-shell Tanks (SST) and Doubleshell Tanks (DST).

TRADEMARK DISCLAIMER. Reference herein to any specific comercial product, process, or service by trade name, trademark, manufacturer, or otherwise, does not necessarily constitute or imply its endorsement, recommendation, or favoring by the United states Government or any agency thereof or its contractors or subcontractors.

Printed in the United States of America. To obtain copies of this document, contact: WHC/BCS Document Control Services, P.O. Box 1970, Mailstop H6-08, Richland WA 99352, Phone (509) 372-2420; Fax (509) 376-4989.
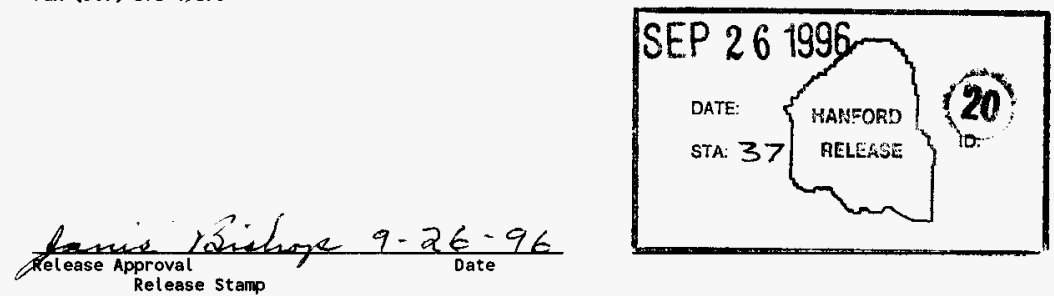
P.O. Box 1970 Richland, WA 99352

September 26, 1996

9654303

Mr. B. L. Nicoll, Director

Waste Retrieval Division

U.S. Department of Energy

Richland Operations office

Richland, Washington 99352

Dear Mr. Nicoll:

\section{MILESTONE T2E-96-128 COMPLETION}

The purpose of this letter is to confirm that Westinghouse Hanford Company (WHC) has completed Milestone T2E-96-128, "Issue the Waste Retrieval

Technical Requirements" on September 24, 1996. The attached document constitutes completion of the milestone and is attached for your information.

This milestone completion effort consisted of analyzing the requirements allocated to the Waste Retrieval function from the Tank Waste Remediation System, Functions and Requirements Document (FRD), WHC-SD-WM-FRD-020, Draft Revision A, January 1996. Since January the FRD has been revised several times and Revision OA is presently in internal WHC review with a milestone to submit it to RL by September 30,1996. This Revision 0 of the Technical Requirements is planned to be updated to incorporate changes to the FRD after review and approval by RL and the activity is included in the September 23 Multi-Year Program Plan submittal for FY 1997.

If you have any questions, or require further information, please contact Mr. R. P. Marsha11 at (509) 373-0663 or Mr. D. G. Baide at (509) 376-3274.

Very truly yours,

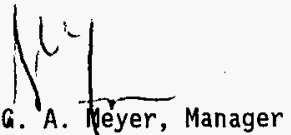

Retrieval Program TWRS Disposal Programs

jg

Attachment

RL - G. H. Sanders

W. J. Taylor

C. D. West

A. H. Wirkkala (w/o attachment)

W. R. Wrzesinski 
WHC-SD-WM-TRD-004, Rev. 0

\title{
TECHNICAL REQUIREMENTS SPECIFICATION FOR TANK WASTE RETRIEVAL
}

\author{
Prepared By: \\ LOS ALAMOS TECHNICAL ASSOCIATES, INC. \\ Richland, WA \\ For: \\ WESTINGHOUSE HANFORD COMPANY \\ Richland, WA \\ April 1996
}

$a$. 
WHC-SD-WM-TRD-004, Rev. 0

This page intentionally left blank.

$a: i$ 


\section{CONTENTS}

1.0 TECHNICAL REQUIREMENTS SPECIFICATION FOR TANK WASTE

RETRIEVAL - FUNCTION $4.2 .2 \ldots \ldots \ldots \ldots \ldots \ldots \ldots$. . . . . . . . . . . . .

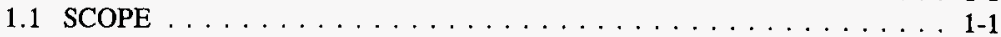

1.1 .1 Identification . . . . . . . . . . . . . . . . . . 1-1

1.1.2 Tank Waste Remediation System Overview ............ 1-1

1.1 .3 Waste Retrieval System . . . . . . . . . . . . . . . 1-1

1.1 .4 Document Overview ...................... . . . . . . . . . . . . . . . . . .

1.2 APPLICABLE DOCUMENTS . . . . . . . . . . . . . . . . . . . . . . . . . . . . . . . . . . . . . . . .

1.2.1 Government Sources ..................... 1-2

1.2 .2 Non-Government Sources $\ldots \ldots \ldots \ldots \ldots \ldots$ 1-3 . . . . . . . . . . . . . . . . . . . . . .

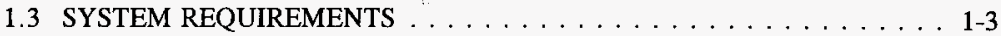

1.3 .1 System Definition ...................... . . . . . . . . . . .

1.3.1.1 Interface Description . . . . . . . . . . . . 1-5

1.3.1.2 Risk Assumptions .................. 1-6

1.3.2 Characteristics ..................... 1-7

1.3.2.1 Performance Characteristics . . . . . . . . . . . . 1-7

1.3.2.2 System Capability Relationships . . . . . . . . . . . . 1-8

1.3.2.3 External Interface Requirements . . . . . . . . . . . 1-10

1.3.2.5 System Quality Factors . . . . . . . . . . . . . . . 1-31

1.3.2.6 Environmental Conditions . . . . . . . . . . . 1-33

1.3.2.7 Transportability . . . . . . . . . . . . . . . 1-34

1.3.2.8 Flexibility and Expansion ... . . . . . . . . . 1-34

1.3.2.9 Portability ..................... 1-34

1.3.3 Design and Construction .................. 1-34

1.3.3.1 Materials (Structure, Shielding) . . . . . . . . . . 1-34

1.3.3.2 Radiation . . . . . . . . . . . . . . . . . . 1 1-42

1.3.3.3 Name Plates and Product Markings ... . . . . . . . 1-43

1.3.3.4 Workmanship . . . . . . . . . . . . . . . . . . 1-44

1.3.3.5 Interchangeability . . . . . . . . . . . . . 1-44

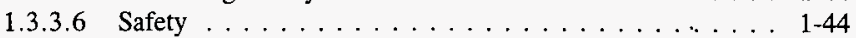

1.3.3.7 Human Engineering . . . . . . . . . . . . . . . 1-48

1.3.3.8 Nuclear Control . . . . . . . . . . . . . . . . . . . . . . . . . . . . . . . . . . . . . . .

1.3.3.9 System Security . . . . . . . . . . . . . . . . . . . . . 1-49

1.3.3.10 Government Furnished Property Capacity . . . . . . . . 1-49

1.3 .4 Documentation . . . . . . . . . . . . . . . 1-50

1.3.5 Personnel and Training . . . . . . . . . . . . . . . 1-51

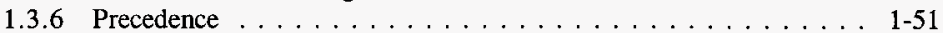

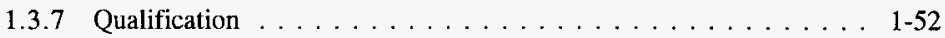

1.3 .8 Standard Sample . . . . . . . . . . . . . . . . 1-52 


\section{CONTENTS (Continued)}

1.4 QUALITY ASSURANCE PROVISIONS $\ldots \ldots \ldots \ldots \ldots \ldots \ldots$ 1-52

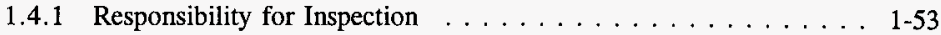

1.4.2 Special Tests and Examinations $\ldots \ldots \ldots \ldots \ldots \ldots \ldots \ldots$ 1-54

1.4.3 Requirements Cross Reference . . . . . . . . . . . . . 1-59

1.5 PREPARATION FOR DELIVERY (or OPERATIONS) $\ldots \ldots \ldots \ldots .1-59$

2.0 TECHNICAL REQUIREMENTS SPECIFICATION FOR SINGLE-SHELL

TANK RETRIEVAL - FUNCTION $4.2 .2 .1 \ldots \ldots \ldots \ldots \ldots \ldots$. . . . . . .

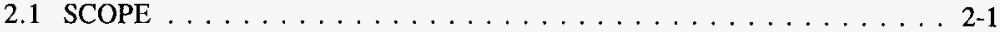

2.1 .1 Identification $\ldots \ldots \ldots \ldots \ldots \ldots \ldots \ldots \ldots \ldots \ldots . \ldots \ldots \ldots$

2.1.2 Single-shell Tank Waste Retrieval System Overview . . . . . . . 2-1

2.1.3 Chapter Overview .................... 2-1

2.2 APPLICABLE DOCUMENTS $\ldots \ldots \ldots \ldots \ldots \ldots \ldots \ldots \ldots \ldots . \ldots \ldots$

2.3 SYSTEM REQUIREMENTS $\ldots \ldots \ldots \ldots \ldots \ldots \ldots \ldots \ldots \ldots \ldots . \ldots \ldots$

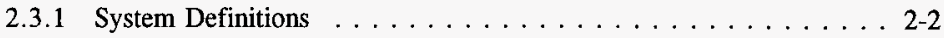

2.3.1.2 Interface Description . . . . . . . . . 2-4

2.3.1.3 Risk Assumptions . . . . . . . . . . . . . . 2-4

2.3.2 Characteristics . . . . . . . . . . . . . . . . 2-7

2.3.2.1 Performance Characteristics . . . . . . . . . . . 2-7

2.3.2.2 System Capability Relationships $\ldots \ldots \ldots \ldots \ldots$. 2-10

2.3.2.3 External Interface Requirements . . . . . . . . . 2-12

2.3.2.4 Physical Characteristics . . . . . . . . . . 2-15

2.3.2.5 System Quality Factors . . . . . . . . . . . . 2-15

2.3.2.6 Environmental Conditions . . . . . . . . . . 2-15

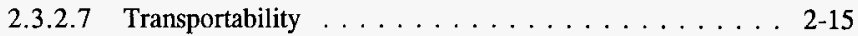

2.3.2.8 Flexibility and Expansion $\ldots \ldots \ldots \ldots \ldots \ldots .2-15$

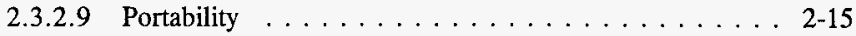

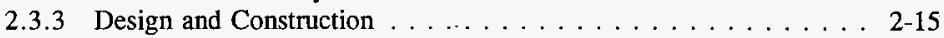

2.3.4 Documentation . . . . . . . . . . . . . . . 2-16

2.3.5 Logistics . . . . . . . . . . . . . . . . . 2-16

2.3.6 Personnel and Training . . . . . . . . . . . . . 2-16

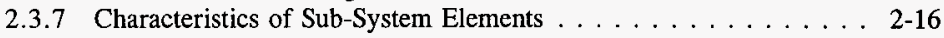

2.3.7.1 Project W320: 241-C-106 Sluicing . . . . . . . 2-16

2.3.7.2 Initial Single-Shell Tank Retrieval System (ISSTRS)

Project . . . . . . . . . . . . . . 2-17

2.3.7.3 Acquire Commercial Technology for Retrieval . . . . . 2-18

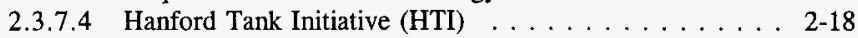

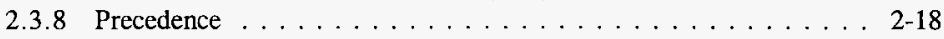

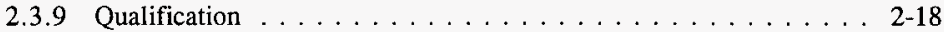

2.3.10 Standard Sample . . . . . . . . . . . . . . 2-20 


\section{CONTENTS (Continued)}

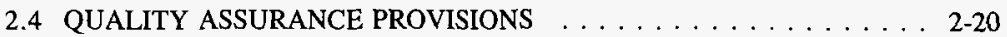

2.4.1 Responsibility for Inspections . . . . . . . . . . . . . . 2-20

2.4.2 Special Tests and Examinations . . . . . . . . . . . 2-20

2.4.3 Requirements Traceability Matrix $\ldots \ldots \ldots \ldots \ldots \ldots . \ldots 2-23$

2.5 PREPARATION FOR DELIVERY (OR OPERATIONS) . . . . . . 2-23

3.0 TECHNICAL REQUIREMENTS SPECIFICATION FOR DOUBLE-SHELL

TANK RETRIEVAL - FUNCTION 4.2.2.2 . . . . . . . . . . . 3-1

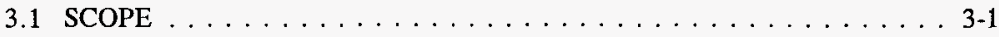

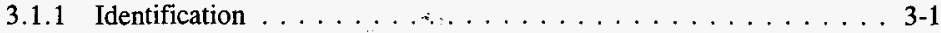

3.1.2 Double-Shell Tank Waste Retrieval System Overview . . . . . . 3 3-1

3.1 .3 Chapter Overview . . . . . . . . . . . . . . 3-2

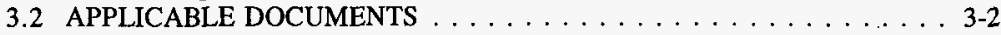

3.3 SYSTEM REQUIREMENTS $\ldots \ldots \ldots \ldots \ldots \ldots \ldots \ldots \ldots \ldots \ldots$. $\ldots \ldots \ldots$

3.3.1 System Definitions . . . . . . . . . . . . . . . . 3-2

3.3.1.1 Interface Description . . . . . . . . . . . . 3-4

3.3.1.2 Risk Assumptions . . . . . . . . . . . . . 3-4

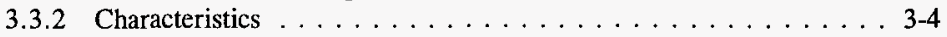

3.3.2.1 Performance Characteristics . . . . . . . . . . . 3-4

3.3.2.2 System Capability Relationships . . . . . . . . . . 3-8

3.3.2.3 External Interface Requirements . . . . . . . . . 3-10

3.3.2.4 Physical Characteristics . . . . . . . . . . . 3-13

3.3.2.5 System Quality Factors . . . . . . . . . . . . . 3-13

3.3.2.6 Environmental Conditions . . . . . . . . . . . . 3-14

3.3.2.7 Transportability . . . . . . . . . . . . . 3-14

3.3.2.8 Flexibility and Expansion $\ldots \ldots \ldots \ldots \ldots \ldots$. . . . . . . . .

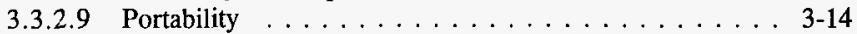

3.3.3 Design and Construction $\ldots \ldots \ldots \ldots \ldots \ldots \ldots \ldots \ldots \ldots . \ldots \ldots$

3.3.4 Documentation . . . . . . . . . . . . . . . . . 3-14

3.3 .5 Logistics . . . . . . . . . . . . . . . . . . 3-14

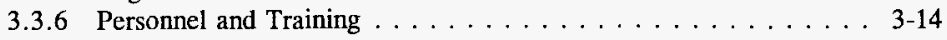

3.3.7 Characteristics of Sub-System Elements . . . . . . . . . 3-14

3.3.7.1 Project W-151, 101-AZ Retrieval . . . . . . . . 3-16

3.3.7.2 Project W-211, Initial DST Waste Retrieval . . . . . 3-16

3.3.7.3 DST Waste Consolidation . . . . . . . . . 3-16

3.3.7.4 Other Projects . . . . . . . . . . . . . 3-16

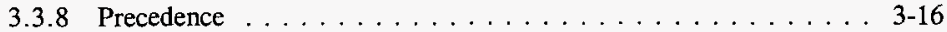

3.3.9 Qualification ..................... 3-17

3.3.10 Standard Sample . . . . . . . . . . . . . 3-17 


\section{CONTENTS (Continued)}

3.4 QUALITY ASSURANCE PROVISIONS . . . . . . . . . . 3-17

3.4.1 Responsibility for Inspections . . . . . . . . . . . . . . 3-17

3.4.2 Special Tests and Examinations . . . . . . . . . . . . 3-17

3.4.3 Requirements Cross Reference . . . . . . . . . . . 3-20

3.5 PREPARATION FOR DELIVERY (OR OPERATIONS) $\ldots \ldots \ldots \ldots$. . . . 


\section{LIST OF FIGURES}

1-1. Waste Retrieval Functional Breakdown Structure $\ldots \ldots \ldots$. . . . . . . . . 1-4

2-1. SST Waste Retrieval Functional Breakdown Structure . . . . . . . . . 2-3

2-2. [4.2.2.1] Retrieve SST Waste $(\mathrm{N}$ - Squared Diagram) $\ldots \ldots \ldots \ldots . \ldots . \ldots 2-5$

2-3. Single-Shell Tank Waste Retrieval Sub-System Elements . . . . . . . . . . . 2-19

3-1. Double-Shell Tank Waste Retrieval Functional Breakdown Structure . . . . . . . 3-3

3-2. [4.2.2.2] Retrieve DST Waste (N-Squared Diagram) . . . . . . . . . . 3-5

3-3. Double-Shell Tank Waste Retrieval Sub-System Elements . . . . . . . . . . . . 3-14

\section{LIST OF TABLES}

1-1. Risk Assumptions $\ldots \ldots \ldots \ldots \ldots \ldots \ldots \ldots \ldots \ldots \ldots \ldots \ldots$

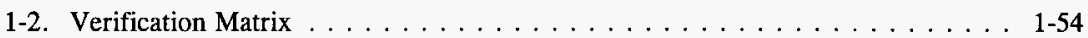

1-3. Requirements Traceability Matrix $\ldots \ldots \ldots \ldots \ldots \ldots \ldots \ldots \ldots \ldots$

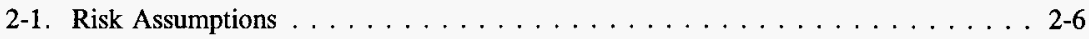

2-2. Maximum Soil Depth/Live Loads Above Tanks . . . . . . . . . . 2-11

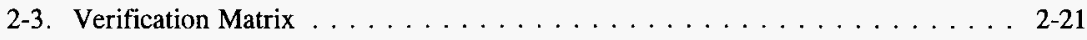

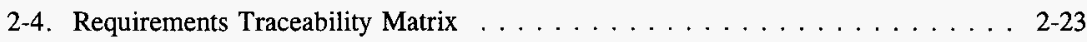

3-1. Risk Assumptions $\ldots \ldots \ldots \ldots \ldots \ldots \ldots \ldots \ldots \ldots \ldots \ldots \ldots \ldots$

3-2. Maximum Soil Depth/Live Loads Above Tanks . . . . . . . . . . . 3-8

3-3. Tank Waste Type Matrix $\ldots \ldots \ldots \ldots \ldots \ldots \ldots \ldots . \ldots \ldots \ldots . \ldots \ldots$

3-4. Verification Matrix $\ldots \ldots \ldots \ldots \ldots \ldots \ldots \ldots \ldots . \ldots \ldots \ldots . \ldots \ldots$

3-5. Requirements Traceability Matrix . . . . . . . . . . . . . 3-19 


\section{LIST OF TERMS}

\section{Acronyms}

ACTR

ALARA

ANSI

ATP

AWP

BACT

BARCT

CC

CFR

CP

DC

DCG

DCRT

DN

DOE

DSSF

DST

DQO

EDE

EEM

EIS

ETF

FEMP

HEPA

HLW

HSRCM

HTI

HVAC

ICSSC

ISSTRS

LERF

LLW

MUST

NCAW

NCRW

NEHRP

NRC

OSD

OTP
Acquire Commercial Technology Retrieval

As Low As Reasonably Achievable

American National Standards Institute

Acceptance Test Procedure

Air and Water Permit

Best Available Control Technology

Best Available Radionuclide Control Technology

Complexant Concentrate

Code of Federal Regulations

Concentrated Phosphate Waste

Dilute Complexant Waste

Derived Concentration Guide

Double Contained Receiving Tank

Dilute Non-complexant Waste

U.S. Department Of Energy

Double-shell Slurry Feed

Double-shell Tank

Data Quality Objectives

Effective Dose Equivalent

Environmental Emission Management

Environmental Impact Statement

Effluent Treatment Facilities

Facility Effluent Monitoring Plant

High Efficiency Particulate Air

High Level Waste

Hanford Site Radiological Control Manual

Hanford Tank Initiative

Heating, Ventilating and Air Conditioning

Interagency Committee of Seismic Safety and Construction

Initial Single-Shell Tank Retrieval System

Liquid Effluent Retention Facility

Low Level Waste

Miscellaneous Underground Storage Tank

Neutralized Current Acid Waste

Neutralized Cladding Removal Waste

National Earthquake Hazards Reduction Program

nuclear Regulatory Commission

Operating Specification Document

Operations Test Procedure 


\section{LIST OF TERMS (Continued)}

$\begin{array}{ll}\text { ORR } & \text { Operational Readiness Review } \\ \text { PFP } & \text { Plutonium Finishing Plant } \\ \text { PNL } & \text { Pacific National Laboratory } \\ \text { ppm } & \text { Parts per Million } \\ \text { PSD } & \text { Prevention of Significant Deterioration } \\ \text { PSO } & \text { Plant Safety Officer } \\ \text { QAPP } & \text { Quality Assurance Program Plan } \\ \text { RACT } & \text { Reasonably Available Control Technology } \\ \text { RAEP } & \text { Radionuclide Air Emission Program } \\ \text { RCRA } & \text { Resource Conservation and Recovery Act of 1976 } \\ \text { RL } & \text { Richland Operations Office } \\ \text { SALDS } & \text { Solid and Liquid Disposal System } \\ \text { SpG } & \text { Specific Gravity } \\ \text { SST } & \text { Single-shell Tank } \\ \text { SWDP } & \text { State Waste Discharge Permit } \\ \text { TBD } & \text { To Be Determined } \\ \text { TEDF } & \text { Treated Effluent Disposal Facility } \\ \text { TGA } & \text { Thermo Gravimetric Analysis } \\ \text { TOC } & \text { Total Organic Carbon } \\ \text { TOX } & \text { Total Organic Halogen } \\ \text { TPA } & \text { Tri-Party Agreement } \\ \text { TRU } & \text { Transuranic } \\ \text { TWRS } & \text { Tank Waste Remediation System } \\ \text { USQ } & \text { Unreviewed Safety Question } \\ \text { WAC } & \text { Washington State Administrative Code } \\ \text { WHC } & \text { Westinghouse Hanford Company } \\ \text { WIPP } & \text { Waste Isolation Pilot Plant } \\ \text { WPS } & \text { Waste Pretreatment Storage } \\ \text { WRS } & \text { Waste Retrieval System } \\ \text { WTS } & \text { Waste Tank Storage } \\ & \end{array}$

\section{Definitions}

Availability - Availability is a measure of the degree to which an item is in an operable and committable state at any one point in time. Mathematically, there are several ways availability can be calculated, depending on the desired use. Conceptually, availability is total time minus time lost due to failure/maintenance. Hence, availibility is dependent on the reliability and maintainbility of equipment. 


\section{LIST OF TERMS (Continued)}

Functions and Requirements - The functions are statements of purpose, defining what the system must do; requirements indicate how well the function must be accomplished. The Tank Waste Remediation System F \& Rs are detailed to the fourth level of architecture in WHC-SD-WM-FRD-020 Draft Revision A, Tank Waste Remediation System Functions and Requirements Document (January 1996).

Dangerous/Hazardous Waste - At the Hanford Site, this term usually means nonradioactive chemical toxins or otherwise potentially dangerous materials such as sodium, heavy metals, beryllium, or some organics.

High-Level Waste - The highly radioactive waste that results from the reprocessing of spent nuclear fuel, including liquid waste produced directly in reprocessing and any solid waste derived from the liquid, that contains a combination of transuranic waste and fission products in concentrations requiring permanent isolation (DOE Order 5820.2A, Radioactive Waste Management [DOE 1988]).

Logistics Reliability - This is the measure selected to account for or address all incidents that require a response from the logistics system.

Low-Level Waste - Any gaseous, liquid or solid waste that contains radioactivity and is not classified as high-level waste, transuranic waste, or spent nuclear fuel or byproduct material as defined by DOE Order 5820.2A, Radioactive Waste Management (DOE 1988). Test specimens of fissionable material irradiated for research and development only, and not for the production of power or plutonium, may be classified as low-level waste, provided the concentration of transuranic is $<100 \mathrm{nCi} / \mathrm{g}$.

Maintainability - Maintainability is a characteristic of design and installation expressed as the probability that an item will be retained in, or restored to, a specific condition within a given period of time, when maintenance is performed in accordance with prescribed procedures and resources.

Mission Reliability - Mission reliability is the probability that a system will perform mission-essential functions for a period of time under the conditions stated in the mission profile. Reliability measures are concerned with the expected frequency of failure.

Maintenance - Maintenance is defined as all actions required to retain or restore the system to a specified condition. This may include diagnosis, repair or inspection. 


\section{LIST OF TERMS (Continued)}

Reliability - Reliability is defined as the probability that an item will perform its intended function for a specified interval under stated conditions. This definition does not specifically consider the effect of the age of the system. Reliability can be further subdivided into mission reliability and logistics reliability. Reliability measures are concerned with the expected frequency of failure.

\section{Reference:}

Tank Waste Remediation System Functions and Requirements Document, WHC-SD-WMFRD-020 Draft Revision A, January 1996. 
WHC-SD-WM-TRD-004, Rev . 0

This page intentionally left blank. 


\subsection{TECHNICAL REQUIREMENTS SPECIFICATION FOR TANK WASTE RETRIEVAL - FUNCTION 4.2.2}

\section{$1.1 \quad$ SCOPE}

This document provides the technical requirements specification for the retrieval of waste from the underground storage tanks at the Hanford Site. All activities covered by this scope are conducted in support of the Tank Waste Remediation System (TWRS) mission.

\subsubsection{Identification}

Program: Tank Waste Remediation System

Project: Waste Retrieval System

\subsubsection{Tank Waste Remediation System Overview}

The DOE established the TWRS to manage and immobilize for disposal the wastes contained in the underground storage tanks at the Hanford Site. The mission of the TWRS is to store, treat, and immobilize highly radioactive Hanford waste (current and future tank waste and the encapsulated cesium and strontium) in a safe, environmentally sound, and cost effective manner. An analysis of the TWRS mission has been prepared (WHC 1995). The TWRS mission analysis provides the initial scope of activities that must be performed to accomplish the TWRS mission. Analyses have been conducted to identify functions and requirements necessary to accomplish the TWRS mission (WHC 1996).

\subsubsection{Waste Retrieval System}

The waste retrieval system is a major architecture element of the Tank Waste Remediation System (TWRS). The waste retrieval system mobilizes sludge, and solids contained within the Hanford Site tanks waste storage system which consists of mixed waste underground storage tanks and ancillary equipment. The vast majority of the waste the TWRS has a source based definition of high-level waste (HLW).

After mobilization, the tank waste sludges and solids are transported to the waste processing system for treatment. The waste retrieval system also provides the means to transfer waste from the waste storage system. To the extent practical, the waste retrieval system shall use existing components of the waste transfer system (e.g., underground piping, diversion boxes, and valve pits) to transfer mobilized tank waste to the processing system. 
Tank space management constitutes a major interface between the tank waste system and waste retrieval system. The TWRS has 28 DSTs with about $120,000 \mathrm{~m}^{3}$ of capacity. To manage, the waste within this capacity requires TWRS to transfer- waste among the tanks. The waste retrieval system provides equipment to consolidate waste sludges as part of the overall waste management actions of the Tank Waste System architecture.

The waste retrieval system also includes demonstration of technologies for mobilization of tank wastes, Phase I HLW pretreatment processing for privatization, and transfer of HLW and low-activity waste to the Phase I processing facilities. Demonstration of tank waste mobilization technology is necessary to verify selected waste retrieval architectures can achieve established system performance requirements, thereby reducing program uncertainties and risks. Demonstration of the Phase I HLW pretreatment processing ensures the U.S Department of Energy (DOE) can provide waste to the privatization contractors per contractual commitments.

\subsubsection{Document Overview}

This system specification has been prepared using the format guidelines of military standard (MIL-STD) 490; system/segment specification. All sections specified in MIL-STD-490 have been included in this document. In keeping with the conventions of MIL-STD-490, if a section is not applicable for this specification, the section title is provided followed by a statement identifying the section as not applicable.

\section{$1.2 \quad$ APPLICABLE DOCUMENTS}

The requirements for accomplishing the waste retrieval system mission come from many source documents. These documents define the requirements the waste retrieval system's products, effluents, and other interfaces must comply with to successfully complete its mission. These documents come from both government and non-government sources.

\subsubsection{Government Sources}

Federal government, Washington State regulations, and Department of Energy orders, have been reviewed to determine constraints applicable to conducting the Tank Waste Remediation System mission. The TWRS Functions and Requirements document identifies the applicable constraints and the allocation of these constraints to functions and interfaces of the Tank Waste Remediation System (WHC 1996).

System specification requirements have been developed from these constraints and are identified in Sections 1.3 and 1.4. A requirements traceability matrix is provided in Table 1-3 identifying the source constraint for each derived specification requirement. 


\subsubsection{Non-Government Sources}

The WHC has reviewed DOE orders, federal regulations, and Washington State regulations to provide a consistent interpretation of the constraints applicable to the Hanford site. These interpretations are contained in WHC control manuals (CM). In addition, the WHC has conducted technical analyses (e.g., safety analyses, data quality objectives, etc.) of the existing physical components that comprise the TWRS. These technical analyses have provided further definition of the TWRS.

The WHC control manuals and technical analysis reports are designated as non-government documents. The TWRS Functions and Requirements document identifies the performance requirements contained in non-government documents and the allocation of these requirements to functions and interfaces of the Tank Waste Remediation System (WHC 1996).

System specification requirements have been developed from these non-government documents and are identified in Sections 1.3 and 1.4. A requirements traceability matrix is provided in Table 1-3 identifying the source constraint for each derived specification requirement.

\subsection{SYSTEM REQUIREMENTS}

\subsubsection{System Definition}

The Tank Waste Remediation System Function and Requirements established function 4.2 .2 Retrieve Tank Waste. This function is defined as: The removal of wastes (i.e., liquids, saltcake, sludges, in-tank hardware, and discrete sources) from underground storage tanks (USTs) and the transfer of these wastes to the Process Waste function. Wastes will be removed to the extent required for turnover of the tanks for closure. This function does not include the removal of previously retrieved waste from the DSTs (see the Store In-Process Waste function). This function also includes treatment/preparation of liquid, gaseous, and solid waste generated during retrieval of tank wastes. The function Retrieve Tank Waste has been decomposed into the following sub-functions. Figure 1-1 represents the functional breakdown structure.

4.2.2.1 Retrieve SST Waste. The removal of wastes (i.e., saltcake, sludges, in-tank hardware, and discrete sources) from single-shell tanks (SSTs) and the transfer of these wastes to the Store In-Process Waste function. Wastes will be removed to the extent required for turnover of the tanks to closure. Includes retrieval and consolidation of tank space. 


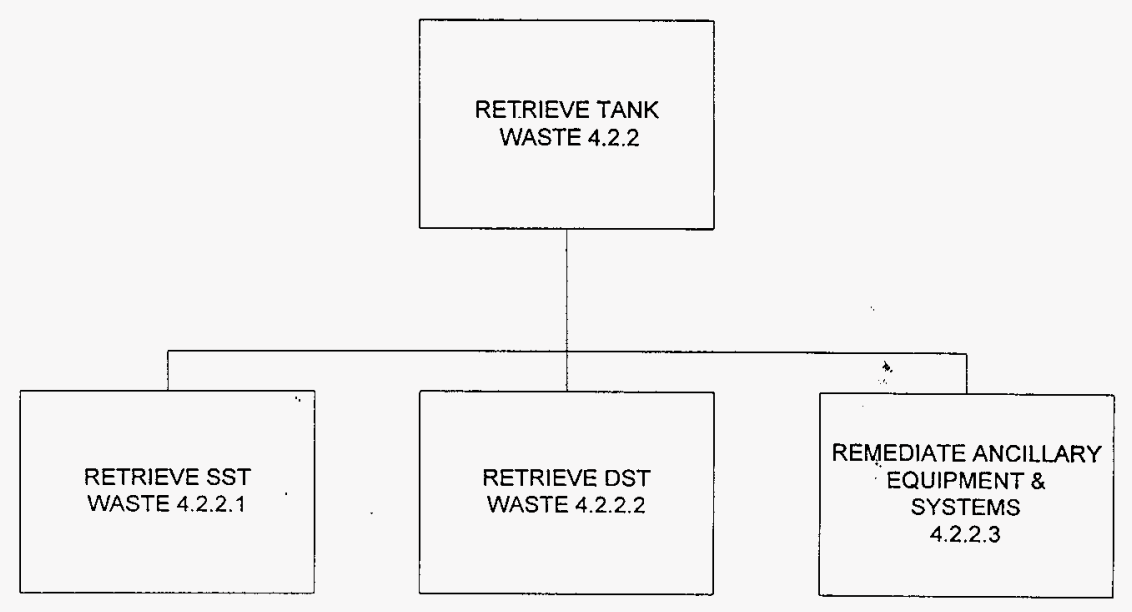




\subsubsection{Retrieve DST Waste. The removal of wastes}

(i.e., liquids, saltcake, sludges, and in-tank hardware) from

double-shell tanks (DSTs) and the transfer of these wastes to the

Store In-Process Waste function. Wastes will be removed to the extent required for turnover of the tanks to closure. This function does not include the removal of previously retrieved waste from the DSTs (see the Store In-Process Waste function). Includes retrieval and consolidation of tank space.

\subsubsection{Remediate Ancillary Equipment and Systems. Wastes} will be removed from the Ancillary Equipment and Systems to the extent required for closure and transferred to the Store In-Process Waste function.

Ancillary Equipment and Systems include MUSTs, double-contained receiver tanks, underground waste transfer pipelines, HVAC ducts, and exhausters, diversion boxes, pump pits, catch tanks, and other equipment associated with Operable Units. Includes retrieval and consolidation of tank space.

\subsubsection{Interface Description}

The Waste Retrieval System (WRS) has several interfaces with the other portions of the TWRS. These interfaces include:

- Tanks and ancillary equipment with waste

- Infrastructure upgrades

- Tanks and ancillary equipment for reuse

- Waste

- Closure ready operable units .

The WRS interfaces have different degrees of maturation.

\section{Tanks and Ancillary Equipment with Waste}

The WRS receives tanks and ancillary equipment with waste from the Waste Tank Storage (WTS). These tanks include both DSTs and SSTs. The DSTs undergo multiple retrieval operations. While, the SSTs undergo a single retrieval operation prior to closure.

\section{Infrastructure Upgrades}

The WRS receives infrastructure upgrades from the WTS. The W-314 project provides these upgrades for the WTS. As tanks and ancillary equipment transfer to WRS, these upgrades provide improvements to the system for waste retrieval. 
The upgrades include enhancements to the transfer, instrument and control, utilities, and HVAC infrastructure of the tank farms. These upgrades must meet both the WTS and the WRS performance requirements.

\section{Tanks and Ancillary Equipment for Reuse}

After waste retrieval, the WRS returns tanks and ancillary equipment to WTS for reuse. The W-211 Project provides equipment for waste retrieval that allows reuse of the tanks. Waste consolidation provides the primary method for tank reuse (e.g., TRU consolidation allows for the reuse of Tank 241-SY-101 for stabilization of 200 West Area SSTs).

\section{Waste}

The WRS transfers waste to the Waste Pretreatment Storage (WPS). This waste consists of supernatants and sludges that pass to the 4.2.3.2 Pretreat Solids function. The waste has a total mass of about $240,000 \mathrm{MT}$ and total volume of about 140,000 cubic meters at five molar sodium.

\section{Closure Ready Operable Units}

After final retrieval, the WRS transfers closure ready operable units to WDS. The closure ready operable units consist of tanks and ancillary equipment with waste removed to the extent necessary to comply with the RCRA closure requirements.

\subsubsection{Risk Assumptions}

Table 1-1 lists the major program risk assumptions applicable to Tank Waste Retrieval. Risks which are specific to Tank Waste Retrieval sub-functions are given in their respective chapters of this report.

Table 1-1. Risk Assumptions.

\begin{tabular}{|c|c|}
\hline His). Q & Molental 8 onseaverioe \\
\hline $\begin{array}{l}\text { Sufficient funds not available to retrieve waste } \\
\text { from SSTs/MUSTs by } 2018 \text {, close them by } \\
2024 \text {, or completely immobilize all DST } \\
\text { waste by } 2028 \text {. }\end{array}$ & $\begin{array}{l}1 . \quad \text { Unplanned delay in tank } \\
\text { retrieval. } \\
2 . \\
\text { farm closure. }\end{array}$ \\
\hline $\begin{array}{l}\text { Health and safety issues may not be resolved } \\
\text { in a timely manner to meet regulatory and } \\
\text { project schedule requirements. }\end{array}$ & Work stoppage or delay. \\
\hline
\end{tabular}

\subsubsection{Characteristics}

\subsubsection{Performance Characteristics}




\subsection{Waste Minimization/Volume Reduction}

\section{Technical and Administrative Controls}

Technical and administrative controls shall be directed to reducing the gross volume of waste generated and/or the amount of radioactivity requiring disposal. Transuranic waste reduction efforts shall be based on the implementation of techniques such as process modification, process optimization, materials substitution, decontamination, assay of suspect waste, and new technology development.

Source: $\quad$ DOE5820.2A, Chapter II, 3.b(1)

DOE5820.2A, Chapter III, 3.c(1)

\section{Auditable Programs}

All DOE-low-level waste generators shall establish auditable programs (goals, incentives, procedures, and reports) to assure that the amount of low-level waste generated and/or shipped for disposal is minimized.

Source: DOE5820.2A, Chapter III, 3.c(2)

\section{Design for New Process}

Each DOE-low-level waste generator preparing a design for a new process or process change shall incorporate principles into the design that will minimize the generation of low-level waste.

Source: DOE5820.2A, Chapter III, 3.c(4)

\subsection{Waste Segregation}

\section{Waste Assessment}

Waste generation and waste management systems that significantly change the chemical and physical forms of the waste shall be technically assessed to assure compatibility and retrievability.

Source: $\quad$ DOE5820.2A, Chapter I, 3.b(7)(e)

\section{Waste Separation}

Each DOE-low-level waste generator shall separate uncontaminated waste from low-level waste to facilitate cost effective treatment and disposal.

Source: DOE5820.2A, Chapter III, 3.c(3) 


\section{Waste Evaluation}

Any material that is known to be, or suspected of being contaminated with transuranic radionuclides shall be evaluated as soon as possible in the generating process, and determined to be either recoverable material, transuranic waste, low-level waste, mixed waste, or non-radioactive trash in order to avoid commingling the various material streams.

Source: $\quad$ DOE Order 5820.2A, Chapter II, 3.a(1)

\subsubsection{System Capability Relationships}

\subsection{Definition of Operating Modes}

\subsection{Start-up/Testing}

To assure that projects meet established design requirements and established functional requirements, separate acceptance test procedures (ATP) and operations test procedures (OTP) acceptance/operational testing is conducted.

The ATP normally consists of a formal document which outlines the steps to be followed and data to be documented in demonstrating the acceptability of the new installation.

Operability testing is normally to be completed within 60 days after completion of ATP testing.

An operational readiness review (ORR) shall be conducted prior to full operation of the facility.

Source: DOE 4700.1, Project Management System.

WHC Environmental Emission Management (EEM). shall be notified directly by the appropriate facility management as soon as practicable, but no later than one working day after any radioactively contaminated forced ventilation exhaust systems start-up or shut-down. The date and time for each such exhaust system startup or shutdown shall also be recorded in the facility operating log. This requirement addresses equipment of any size involving any radioactive emissions to air resulting from forced air flow. 
Relocation of any portable exhaust unit (e.g., HEPA-filtered portable exhausters, greenhouse exhausters, or HEPA-filtered vacuums) requires the earliest possible prior notification. Use of hand held HEPA filtered vacuums does not require such notification. Such notification shall also include any shutdown of stack sampling or monitoring systems or any other change that may affect the measurement of airborne radioactive emissions to the environment, including those outlined in the applicable Facility Effluent Monitoring Plan (FEMP). WHC EEM shall then notify WHC Air and Water Permits (AWP) of any shutdown, abnormal operation, or other change in facility operation which could result in an airborne radionuclide emissions violation of applicable standards.

Source: $\quad$ WAC 246-247-090

TWRS F\&R Performance Requirement - WHC-CM-7-5

\subsection{Watch List Tanks}

Transfer waste out of a tank* requires written approval by TWRS and TWRS Nuclear Safety and DOE. Requires sample analysis from both receiving and sending tanks.

*Limit does not apply to the potential Flammable Gas Watch List Tanks denoted by footnote 1 in Appendix B. This exception is a result of discussions held during a Plant Review Committee meeting on May 11, 1995. Tanks identified as potential Flammable Gas Watch List Tanks in the future as a result of a correlation between tank waste levels and atmospheric pressure will qualify for similar exemptions and will also be denoted by footnote 1 in Appendix B.

Source: $\quad$ OSD-T-151-00030, Operating Specification for Watch List Tanks, P. 9, Section 30.2.A.3, (A \& B)

\subsection{Decontamination and Decommissioning}

See Section 1.3.2.3.10 for decontamination and decommissioning requirements.

\subsection{Operating Modes Schedule}

\subsection{Estimated TWRS Schedule}

The TWRS remediation schedule will be as follows:

Phase I Proof of Concept (See POCR Phase I Schedule)

Phase II Full Scale Production

Award 2005

Design, Permitting Licensing, Construction

Low Activity 2005-2011

High Level 2005-2013

Operations 
Low Activity 2011-2021

High Level 2013-2028

$\mathrm{D} \& \mathrm{D}$

Low Activity 2021-2026

High Level Waste 2028-2033

Source: General Schedule Section of 95-PRI-073

\subsection{Annual Forecast}

Generators shall provide an annual forecast in the third quarter of the fiscal year to the field organizations managing the off-site disposal facility to which the waste is to be shipped.

Source: DOE5820.2A, Chapter III, 3.g(2)

\subsubsection{External Interface Requirements}

\subsection{Input: Tank Waste for Retrieval}

Wastes stored in underground tanks that are to be retrieved for treatment, safety issue resolution, or disposal. This waste includes the supernate, saltcake, sludge, and in-tank hardware. In-tank hardware and discrete sources will be dispositioned by the Remediate Solid Waste function.

\subsection{Input: Raw Materials for Retrieve Tank Waste}

Any material or services (e.g., steam, water, air, process chemicals, electricity) needed from outside TWRS for retrieving Tank waste.

\subsection{Raw Material Requirements}

\section{Treatment Reagents}

Treatment reagents shall not be placed in a tank system without proven effective mitigative action if they could cause the tank, its ancillary equipment, or the containment system to rupture, leak, or otherwise fail.

Source: $\quad$ DOE5820.2A, Chapter I, 3.b(7)(d)

\subsection{Input: Recycled Water for Retrieval}

Water used during processing of tank wastes that is now available and appropriate for use by the Retrieve Tank Waste function. 


\subsection{Recycled Water Requirements}

\section{HLW Constituents Limitations}

No additives shall be allowed which would have a detrimental impact on the operation of the HLW immobilization process, interim storage operations, or the volume of immobilized HLW produced.

Source: $\quad$ TWRS F\&R Performance Requirement - HLW Constituents Limitations (WHC-SD-MAR-008)

Issue: A cost benefits analysis on the impacts of additives or inclusion of non-radioactive waste constituents in the separated radionuclides/pretreated HLW has not been conducted.

Required analysis: Analyze the effects of the privatization contractors' flowsheet and additives to the separated radionulides streams.

\section{Recycled Condensate}

Where feasible and cost effective, treated process condensate should be recycled for use in tank waste retrieval and pretreatment process activities.

Source: $\quad$ TWRS F\&R Performance Requirement - Recycle of Water for Tank Waste Retrieval and Pretreatment (E/B-SD-W236-RPT-022, Rev 0)

\subsection{Input: Sanitary Waste Services for Retrieve Tank Waste}

A service that receives, collects, and transfers all sanitary domestic sewer wastes from the Retrieve Tank Waste function for processing in a domestic waste-water sewer treatment processing system.

\subsection{Input: Tank Operations Information}

Retrieve waste requires tank operations information consisting of monitoring and surveillance data which includes: in-tank temperature measurements, pressure measurements, waste level measurements, photographs, emission monitoring data, data from specialty equipment, as well as information related to the structure of the tank and its safety status. Tank operations information is provided by the Store Managed Tank Waste (sub-function Manage System Information) function.

\subsection{Input: Tank Waste Characterization Information}

Tank Waste Characterization Information consists of waste analysis data packages, waste in-situ measurement data, and other statistical data analysis. 
Issue: Characterization performance requirements are not well defined at this time. The number and types of samples and analyses as well as the precision, accuracy, and schedule requirements need to be determined in order to provide characterization capacities and capabilities which are adequate to meet the needs.

Required Analysis: Develop data quality objectives (DQOs) for all TWRS programs needing characterization information. Questions to be addressed by the DQOs include, but are not limited to: What type of sample analyses will be required? How many sample analyses will be performed? Part of the scope of the Characterize Waste function is to develop these DQOs.

\subsection{Tank Characterization Requirements}

Tank Waste Characterization Information shall provide controlled, accessible, and usable data resources (electronic and hard copy). This includes receiving, retrieving, compiling, maintaining, organizing, and supplying tank characterization information as data and reports. The information is put into appropriate databases, which can be accessed by or supplied to on-site and off-site data users.

Source: Characterization Information Accessibility

\section{Chemical Concentrations}

Waste sources shall not exceed the following nitrate, nitrite, and hydroxide concentrations limits. These limits shall be met prior to initiating waste transfers.

Note: Square brackets [ ] signify the mean concentration in moles per liter (M).

For operating temperatures of the receiving tank $\leq 100^{\circ} \mathrm{C}\left(212^{\circ} \mathrm{F}\right)$ :

For $\left[\mathrm{NO}^{-}\right] \leq 1.0 \mathrm{M}$ :

$0.010 \mathrm{M} \leq\left[\mathrm{OH}^{-}\right] \leq 5.0 \mathrm{M}$; and

$0.011 \mathrm{M} \leq\left[\mathrm{NO}_{2}^{-}\right] \leq 5.5 \mathrm{M}$

For $1.0 \mathrm{M}<\left[\mathrm{NO}_{3}^{-}\right] \leq 3.0 \mathrm{M}$ :

$0.1 \mathrm{M} \mathrm{x}\left[\mathrm{NO}^{-}\right] \leq\left[\mathrm{OH}^{-}\right]<10 \mathrm{M}$; and

$\left[\mathrm{OH}^{-}\right]+\left[\mathrm{NO}_{2}^{-}\right] \geq 0.4 \times\left[\mathrm{NO}_{3}^{-}\right]$

For $\left[\mathrm{NO}_{3}^{-}\right]>3.0 \mathrm{M}$ :

$0.3 \mathrm{M} \leq\left[\mathrm{OH}^{-}\right]<10 \mathrm{M}$; and

$\left[\mathrm{OH}^{-}\right]+\left[\mathrm{NO}_{2}{ }^{\circ}\right] \geq 1.2 \mathrm{M}$; and

$\left[\mathrm{NO}_{3}{ }^{\circ}\right] \leq 5.5 \mathrm{M}$ 
For tanks 102-AP, 104-AP and 106-AP the following limits shall apply:

For $\left[\mathrm{NO}_{2}^{-}\right]<0.005 \mathrm{M}$ :

$0.001 \mathrm{M} \leq\left[\mathrm{OH}^{-}\right] \leq 0.02 \mathrm{M}$

Providing these conditions are met:

1. Only "Hanford Facility Wastes" (phosphate and/or sulfate decontamination wastes) may be added to tanks.

2. All liquids added to the tanks must be $<0.005 \mathrm{M}$ [NO2'].

3. Temperature $<50^{\circ} \mathrm{C}\left(122 .{ }^{\circ} \mathrm{F}\right)$.

For normal operating temperature of the receiving tank $>100^{\circ} \mathrm{C}\left(212^{\circ} \mathrm{F}\right)$, if the same limits apply with the exception the $\left[\mathrm{OH}^{-}\right]<4.0 \mathrm{M}$ in all cases, then the waste is acceptable.

For the Aging Waste Tanks:

The chemical concentrations specified in OSD-T-151-00017 apply when the waste contains neutralized current acid waste (NCAW).

Source: $\quad$ TWRS F\&R Performance Requirement - Chemical Concentrations Limits

\section{Waste Characterization}

Liquid and solidified high-level waste shall be characterized consistent with radiation protection requirements to determine its hazardous components, per 40 CFR 261 and 40 CFR 264. Characterization shall satisfy requirements of paragraph $3 b(1)(b)$ and may reflect knowledge of waste generating processes, laboratory testing results, and/or the results of periodic sampling and analysis. Examples of required information are chemical composition, physical properties, radionuclide concentrations, and $\mathrm{pH}$.

Source: $\quad$ DOE5820.2A, Chapter I, 3.b(1)(a)

\section{Low-Level Waste Characterization}

Low-level waste shall be characterized with sufficient accuracy to permit proper segregation, treatment, storage, and disposal. This characterization shall ensure that, upon generation and after processing, the actual physical and chemical characteristics and major radionuclide content are recorded and known during all stages of the waste management process.

Source: $\quad$ DOE5820.2A, Chapter III, 3.d 


\section{TRU Waste Evaluation}

Transuranic waste shall be assayed or otherwise evaluated to determine the kinds and quantities of transuranic radionuclides present prior to storage. Additionally, hazardous waste components shall be estimated or analyzed, whichever is appropriate.

Source: $\quad$ DOE5820.2A, Chapter II, 3.b(2)

\subsection{Input: Tank Farm Geological Data}

Information about the tank farm geology, including soil properties, lithology, history and hydrology.

\subsection{Output: Retrieve Tank Waste Ancillary Equipment and Systems}

Wastes retrieved from Tank ancillary equipment and systems (e.g., MUSTs, DCRTs, underground waste transfer pipelines, HVAC ducts and exhausters, diversion boxes, pump pits, catch tanks, and other equipment associated with Tank operable units).

\subsection{Retrieve Tank Waste Ancillary Equipment and Systems Requirements}

\section{Ancillary Equipment Assessment}

For ancillary equipment, a leak test or other integrity assessment as approved by the Department of Ecology must be conducted at least annually.

Source: $\quad$ WAC173-303-640(4)(i)(c)

\section{Ancillary Equipment Protection}

Ancillary equipment must be supported and protected against physical damage and excessive stress due to settlement, vibration, expansion, or contraction.

Source: WAC173-303-640(3)(f)

\subsection{Output: Retrieve Tank Waste Characterization}

Characterization information needs of the Retrieve/Transfer Tank Waste function that can be transformed into data quality objectives with requirements on analytical measurements, precision, and accuracy. 


\subsection{Retrieve Tank Waste Characterization Requirements}

The waste characterization requirements for supporting Tank waste retrieval are specified in WHC-SD-WM-DQO-008.

Source: $\quad$ TWRS F\&R Performance Requirement -Tank Waste Characterization Requirements

\subsection{Output: Retrieve Tank Waste Excess Facilities}

Facilities that have reached the end of their useful life or have no identifiable or planned programmatic use by the Retrieve Tank Waste function. Excess facilities are transferred to Hanford Site Function 4.1; Deactivate Facilities.-

\subsection{Tank Waste Excess Facilities Requirements}

\section{Program Development}

DOE organizations shall develop and document their programs to provide for the surveillance, maintenance, and decommissioning of contaminated facilities.

Source: DOE5820.2A, Chapter V, 3.a

\section{Responsibility for Contaminated Facilities}

Responsibility for contaminated facilities may be transferred from one program organization to another by mutual agreement of the programs involved. The program organization to which a facility is transferred shall accept full responsibility for surveillance, maintenance, and decommissioning of the facility according to the requirements of this Order. Agreements to transfer facilities for functional purposes shall be in writing and shall identify explicitly the concurrent transfer of responsibility for surveillance, maintenance, and decommissioning.

Source: $\quad$ DOE5820.2A, Chapter V, 3.a(5)

\section{Facility Design}

Facilities in which radioactive or hazardous materials are utilized shall be designed to simplify decontamination and decommissioning and/or increase the potential for reuse. Features and procedures that simplify and facilitate decommissioning shall be identified during the planning and design phase based upon a proposed decommissioning method or conversion to other use.

Source: DOE5820.2A, Chapter V, 3.b 


\section{Identification of Contaminated Facilities}

DOE Program organizations shall identify contaminated facilities under their jurisdiction, document the potential for reuse and recovery of materials and equipment, and develop schedules for decommissioning them. Projects consisting of one or more facilities shall be identified as appropriate, and priorities shall be developed based on:

1. Maintaining employee and public health and safety,

2. Protection of the environment,

3. Compliance with the National Environmental Policy Act, the Resource Conservation and Recovery Act, the Comprehensive Environmental Response, Compensation, and Liability Act, the Superfund Amendments and Reauthorization Act, and other contractual or legal requirements,

4. Cost effective program management (e.g., maintaining manpower pools, selecting economical decommissioning alternatives), and

5. Future site plans.

Program organizations shall assure that, prior to initiation of decommissioning activities, adequate surveillance and maintenance is performed for their surplus facilities to meet applicable radiation protection (DOE 5480.1B), hazardous chemical and safety standards, to maintain physical safety and security, and to reduce potential public and environmental hazards. All high-level waste and stored hazardous materials should be removed by the operator as part of the last operational activities prior to entering into the decommissioning phase.

Source: $\quad$ DOE5820.2A, Chapter V, 3.c

\subsection{Output: Retrieve Tank Waste Garbage}

Ordinary non-radioactive, non-hazardous solid waste generated within the Retrieve Tank Waste function, suitable for disposal in a sanitary landfill.

\subsection{Output: Retrieve Tank Waste Hazardous Waste}

Solid waste generated within the Retrieve Tank Waste function that is classified as hazardous (dangerous) per EPA or State of Washington regulations.

\subsection{Retrieve Tank Waste Hazardous Waste Requirement}




\section{Container Storage}

The regulations in this Section apply to owners and operators of all dangerous waste facilities that store containers of dangerous waste.

Source: WAC173-303-630(1)

\section{Containment}

Container storage areas must have a containment system that is capable of collecting and holding spills and leaks. In addition to the necessary leak containment capacity, uncovered storage areas must be capable of holding the additional volume that would result from the precipitation of a maximum twenty-five year storm of twenty-four hours duration.

Source: WAC173-303-630(7)

\subsection{Output: Retrieve Tank Waste Prepared Solid Waste}

\section{Airborne Releases from Treatment}

Solid waste generated from the retrieve/transfer Tank waste function that has been segregated, packaged, assayed, and certified for transfer to Hanford Site Function 4.3; Remedy Solid Waste, for further treatment or disposal. This includes mixed and radioactive solid waste.

Issue: Need to fully establish the requirements/constraints for the solid waste disposal facility.

Required analysis: Evaluate the following documents to fully establish the Solid Waste Disposal Facility requirements/constraints. The documents are as follows:

DOE/RL 95-07

WDOH RAEP FF-01

\subsection{Tank Retrieval Prepared Solid Waste Requirements}

\section{Waste Analysis}

Before an owner or operator treats, stores, or disposes of any hazardous wastes, or nonhazardous wastes if applicable under [Section] 264.113(d), he must obtain a detailed chemical and physical analysis of a representative sample of the wastes. At a minimum, the analysis must contain all the information which must be known to treat, store, or dispose of the waste in accordance with this part and part 268 of this chapter. 
Source: $\quad$ 40CFR264.13(a)(1)

40CFR268.41(a-c)

40CFR268.42(a)

\section{TRU Concentrations}

Radioactive wastes with quantities of transuranic radionuclides in concentrations of $100 \mathrm{nCi} / \mathrm{g}$ of waste or less shall be considered to be low-level waste, and shall be managed according to the requirements of Chapter III of this Order.

Source: $\quad$ DOE5820.2A, Chapter II, 3.a(3)

\section{TRU Concentration Limits}

The lower concentration limit for transuranic waste $(>100 \mathrm{nCi} / \mathrm{g}$ of waste) shall apply to the contents of any single waste package at the time of assay.

Source: $\quad$ DOE5820.2A, Chapter II, 3.a(2)

\section{TRU Waste Storage}

Newly generated transuranic waste shall be placed in noncombustible packaging that meets DOT requirements.

All Type A transuranic waste containers shall be equipped with a method to prevent pressure buildup. Acceptable pressure-relief devices include permeable gaskets, vent clips, and filtered vents.

Source: $\quad$ DOE5820.2A, Chapter II, 3.d

\section{Transfer of Solid Radioactive Waste}

Transfer of solid radioactive waste to the Hanford Site Solid Waste program for. dispositioning shall be in accordance with criteria specified in the Hanford Site Solid Waste Acceptance Criteria, WHC-EP-0063-4, DOE 1540.1 Material, Transportation and Traffic Management, and DOE 95-SWT-186 for on site shipment.

Source: TWRS F\&R Performance Requirement - Solid Radioactive Waste Transfer

\section{Shipment of Onsite Radioactive Solid Waste}

The shipment of onsite radioactive solid waste shall be in accordance with DOE-95-SWT-186 and CM-2-14 "Hazardous Material Packaging and Shipping", based upon DOE Order 460.1

Source: $\quad$ DOE Order 460.1 


\section{Low-Level Waste Shipment}

The volume of waste and number of shipments of low-level waste shall be minimized and the shipments will be conducted based on plans developed by field organizations. Off site shipment of low-level waste shall be in compliance with DOE 1540.1 .

Source: DOE5820.2A, Chapter III, 3.g(1)

\subsection{Output: Retrieve Tank Waste Transferrable Resources}

Resources from Retrieve Tank Waste activities that have no further Retrieve Tank Waste mission. These include technology, work force, materials, equipment, facilities and infrastructure.

\subsection{Output: Retrieve Tank Waste Treated Gaseous Effluents}

Treated gaseous waste from functions associated with Tank retrieval. Treated gaseous effluents are discharged to the atmosphere.

\subsection{Tank Retrieval Treated Gaseous Effluent Requirements}

\section{Gaseous Emission Limits}

Discharge of hazardous organics, nitrogen dioxide, lead, sulfur oxide/dioxide, particulates, carbon monoxide and ozone will not exceed the limits in 40CFR264.1032(a)(1) or 40 CFR 50. Pressure relief devices shall comply with the control of emission requirements of 40CFR264.1054.

Source: $\quad$ 40CFR264.1032(a)(1) 40CFR50.5

40CFR50.11(a-b) 40CFR50.6

40CFR50.12 40CFR50.8(a)

40CFR50.4 40CFR50.9

40CFR264.1054

\section{Regulations for Air Pollution}

The General Regulations for Air Pollution Sources, WAC 173-400 shall apply except for Sections WAC 173-400-070 (Emission Standards for Certain Source Categories) and WAC 173-400-190 (Requirements for Nonattainment Areas).

Source: $\quad$ TWRS F\&R Performance Requirement - General Regulations for Air Pollution Sources. 


\section{Toxic Air Emissions}

The establishment and/or operation of a new toxic air pollutant source shall install and operate best available control technology for toxics (T-BACT) in accordance with WAC 173-460-060. In addition all sources of emissions, including reasonably available control technology (RACT) as defined under this regulation. It should be noted that NOC approval orders can also contain specifications for control technologies and other conditions for the proposed activity being approved by the agency.

Criteria pollutants are those pollutants subject to the Prevention of Significant Deterioration (PSD) program as enforced by the State of Washington Department of Ecology through WAS 173-400-141. If criteria pollutant(s) from TWRS activities approaches trigger levels specified under WAC 173-400 and 40 CFR 52 (as incorporated by reference) the information required for the PSD process would need to be included in an application to the agency.

Source: $\quad$ TWRS F\&R Performance Requirement - Toxic Air Emissions (Hazardous Air Pollutants)

\section{Toxic Air Pollutants}

Discharge of toxic air pollutants shall be controlled in accordance with the requirements of WAC 173-460.

$\begin{array}{llll}\text { Source: } & \text { WAC173-460-010 } & \text { WAC173-460-070 } & \text { WAC173-460-130 } \\ & \text { WAC173-460-020 } & \text { WAC173-460-080 } & \text { WAC173-460-140 } \\ \text { WAC173-460-030 } & \text { WAC173-460-090 } & \text { WAC173-460-150-Table 1 } \\ \text { WAC173-460-040 } & \text { WAC173-460-100 } & \text { WAC173-460-150-Table 2 } \\ \text { WAC173-460-050 } & \text { WAC173-460-110 } & \text { WAC173-460-150-Table 3 } \\ \text { WAC173-460-060 } & \text { WAC173-460-120 } & \text { WAC173-460-160 }\end{array}$

\section{Radioactive Air Emission Control}

Discharge of radioactive air emissions shall be controlled in accordance with the requirements of WAC 173-247.

$\begin{array}{llll}\text { Source: } & \text { WAC246-247-001 } & \text { WAC246-247-030 } & \text { WAC246-247-075 } \\ & \text { WAC246-247-002 } & \text { WAC246-247-040 } & \text { WAC246-247-080 } \\ & \text { WAC246-247-010 } & \text { WAC246-247-060 } & \text { WAC246-247-085 } \\ & \text { WAC246-247-020 } & \text { WAC246-247-065 } & \text { WAC246-247-100 }\end{array}$

\section{Radionuclide Emission Limits}

The emission of radionuclides in air from the combined discharge of all WHC-managed facilities and all other facilities on the Hanford Site shall not exceed those amounts that would cause an effective dose equivalent (EDE) of $10 \mathrm{mrem} / \mathrm{year}$ to any 
member of the public during any 12-month period. Doses due to $\mathrm{Rn}-220, \mathrm{Rn}-222$, and their respective decay products are excluded from these limits. Doses due to $R n-220, R n-222$, and their respective decay products are subject to DOE limits.

Individual airborne emissions shall not result in the annual average concentration at any ground-level ambient location or other occupied area exceeding any Derived Concentration Guide (DCG) public value specified in Appendix A of this manual. Facilities shall enforce appropriate administrative controls that consider atmospheric conditions relative to operations for the purpose of ensuring compliance with this requirement.

Noble Gases: The annual discharge of $\mathrm{Kr}-85$ from all 200 Area emissions units shall not exceed a combined release of $4 \mathrm{E}+06 \mathrm{Ci} / \mathrm{yr}$.

The discharge of radon (including thoron) and the resultant decay products shall be ALARA. The ALARA-based ACV limit for discharge of Rn-220 or Rn-222 from all WHC facilities combined should not exceed $5 \mathrm{E}-06 \mathrm{Ci} / \mathrm{ml}$ on an annual average basis.

Source: $\quad$ TWRS F\&R Performance Requirement - WHC-CM-7-5, 2.5.2.1(1-3)

\section{Best Available Radionuclide Control Technology (BARCT)}

Whenever the construction, installation or establishment of a new emission unit subject to WAC. 173.480 .60 is contemplated, the project shall utilize best available radionuclide control technology (BARCT).

Addition to, enlargement, modification, replacement, alteration of any process or emission unit or replacement of air pollution control equipment which will significantly change potential radionuclide emissions or significantly change the dose equivalent will require the proposed project to utilize BARCT for emission control.

The procedures specified in chapter 402-80 WAC shall be used to calculate the dose to members of the public at the point of maximum annual air concentration in an unrestricted area where any member of the public may be.

Source: $\quad$ RCW 70.94.331. 86-10-053 (Order 86-04)

WAC 173-480-060

WAC $173-480-070$

\section{BACT \& BARCT}

The use of best available control technology (BACT) and best available control technology for air toxics (T-BACT) is required for the construction, installation or establishment of a new source of nonradioactive emissions subject to those requirements. Air emission calculations shall be performed to support the BACT/BARCT analysis. 
Source: $\quad$ WAC $173-400$

\subsection{Output: Retrieve Tank Waste Treated Liquid Effluents}

Liquid effluents which meet interface acceptance criteria for discharge.

\subsection{Tank Retrieval Treated Liquid Effluent Requirements}

\section{Waste Acceptance}

The dispositioned aqueous waste must meet the acceptance criteria and associated administrative procedures of the 200 Area Treated Effluent Disposal Facility.

Source: TWRS F\&R Performance Requirement - 200 Area TEDF Waste Acceptance Criteria

\section{SWDP Permit}

Comply with the requirements of the State Waste Discharge Permit \#ST 4502 for 200 Area Treated Effluent Disposal Facility.

Source: $\quad$ TWRS F\&R Constraint - SWDP Permit 4502 and Fact Sheet

\section{Waste Certification}

Generator low-level waste certification programs shall be subject to a periodic audit by operators facilities to which the waste is sent by the generator.

Source: $\quad$ DOE5820.2A, Chapter III, 3.e(4)

\subsection{Output: Retrieve Tank Waste Untreated Liquid Effluents}

Generated liquid effluents which require treatment and meet interface acceptance criteria for discharge.

\subsection{Tank Retrieval Untreated Liquid Effluents Requirements}

\section{Effluent Treatment Facility Influent Restrictions}

Discharge of ETF effluent is permitted for discharge to the SALDS infiltration gallery only for ETF treatment of 242-A Evaporator process condensate. 
The discharge of ETF effluent to SALDS for any other ETF influent stream is prohibited unless (Washington Department of) Ecology has provided the Permittee with written approval to allow an alternative ETF influent source(s).

If the Permittee proposes to run a different influent source(s) (other than 242-A evaporator condensate) through ETF, a characterization study must be sent to Ecology for approval.

Source: $\quad$ TWRS F\&R Constraint - Effluent Treatment Facility Influent Restrictions

\section{Waste Acceptance}

The following criteria are derived from regulatory and facility design requirements and must be met.

The waste stream must be characterized to the degree established in RCRA Part B Permit. Analytical procedures used must be consistent with RCRA waste analysis plans.

Only the waste codes listed in the Delisting Petition and the RCRA permit can be accepted for treatment at the ETF, unless the permit and the Delisting Petition are modified.

The absorbed radiation dose to a hypothetical individual at the site boundary cannot increase over permitted levels without a modification to the Radionuclide Air Emission Program (RAEP) permit. Influent concentrations must remain low enough such that this remains true. Radionuclides which have not previously been accounted for, may also force a permit reevaluation.

Acceptance criteria based on operability parameters are listed below. While the following are not mandatory criteria, each must be considered when determining the acceptability of a waste stream sent to the LERF for storage and the ETF for treatment. These criteria may change in response to modifications made to the LERF and ETF.

1. No separable organics.

2. Minimize colloidal matter to protect filters in the ETF from plugging.

3. Minimize concentrations of scale forming compounds, (e.g., calcium sulfate, calcium phosphate, and metal silicates).

4. Minimize concentrations of corrosive constituents, such as chloride and fluoride.

5. Minimize concentration of constituents that can absorb UV light to the extent destruction of targeted organics is significantly compromised. 
6. Significant concentrations of neutral radionuclide species cannot be accepted by the LERF and ETF without jeopardizing compliance with discharge requirements for radionuclides (0.04 times the Derived Concentration Guidelines) per Section 8.4.2.1 of WHC-CM-7-5. Plutonium and Ruthenium are known to form such neutral species.

Source: $\quad$ TWRS F\&R Performance Requirement - Untreated Liquid Effluents

Issue: Documents regarding the LERF/ETF system capabilities must be evaluated to assess additional requirements for inclusion in the "Untreated Liquid Effluent" requirement.

Required Analysis: Evaluate the following documents for requirements to be included in the "Untreated Liquid Effluent" performance requirement:

WHC-SD-ETF-WAC-001

SWDP ST-4500

NOC $93-3$

AIR 93-806

DOE/RL-92-72, Rev. 1

OSD-T-151-00029, Rev. B-0

\subsection{Output: Retrieved Tank Waste}

Waste retrieved and transferred to another facility for interim storage and feed staging.

Issue: Documents regarding the Tank Farm capabilities and the effects of returning wastes (including any additives) must be evaluated to assess additional requirements for inclusion in the "Tank Farms Waste Acceptance" performance requirement. Due date is TBD (after contract award).

Required Analysis: Evaluate the following documents for requirements to be included in the "Tank Farms Waste Acceptance" performance requirement:

WHC-SD-WM-EV-053, Rev. 2 and Rev. 3 (draft)

DOE/RL-95-07

WDOH RAEP FF-01

Due date: TBD (after contract award)

\subsection{Retrieved Tank Waste Requirements}

\section{Base Feeds}

Waste in four underground waste storage tanks has been designated as source material for Phase $1 \mathrm{HLW}$ feeds. The designated tanks are 101-AZ, 102-AZ, $102 \mathrm{AY}$, and $106 \mathrm{C}$. 
Source: $\quad$ TWRS F\&R Performance Requirement - Base Feeds

\section{Chemical Compatibility}

Interfacing waste sources shall be categorized according to the Waste Reactivity Group Compatibility Matrix documented in WHC-SD-WM-OCD-015, Rev. 1, and the potential chemical compatibility hazards identified prior to acceptance into a DST.

Source: TWRS F\&R Performance Requirement - Chemical Compatibility

\section{Complexant Waste Segregation}

Waste sources shall determine if the source is a complexant waste. Wastes with a mean [TOC] (total organic carbon concentration) $>10 \mathrm{~g} / \mathrm{L}$ at double-shell slurry feed (DSSF) composition, shall be transferred to a complexant waste tank.

Source: $\quad$ TWRS F\&R Performance Requirement - Complexant Waste Segregation

\section{Criticality Prevention}

Interfacing waste sources shall ensure that the criticality prevention limits are met prior to initiating waste transfers.

Source: $\quad$ TWRS F\&R Performance Requirement - Criticality Prevention Requirement

\section{Corrosion Control}

The chemistry of liquid high-level waste shall be adjusted to control corrosion within design limits for the storage system.

Source: DOE5820.2A, Chapter I, 3.b(7)(c)

\section{Energetics}

Transfers shall be allowed if the waste has no separable organic and the source and receiving wastes (individually) have an absolute value of the exotherm/endotherm ratio $<1.0$ (i.e., no net exotherms) as evaluated from laboratory thermal analysis differential scanning calorimetry (DSC) and thermo-gravimetric analysis (TGA) conducted up to $500^{\circ} \mathrm{C}$.

Source: $\quad$ TWRS F\&R Performance Requirement - Energetics 


\section{Heat Generation Limits}

A technical evaluation which determines the conditions needed for safely receiving and storing the waste shall be required if the ratio is $\geq 1$.

The sum of the receiving tank waste and the source waste heat generation rate shall be $\leq$ the OSD limit for the receiving tank in order for the transfer to take place. A technical evaluation shall be required to verify the heat generation rate limit shall not be exceeded when the uncertainties associated with the sample analysis and calculations is unusually large.

Source: TWRS F\&R Performance Requirement - Heat Generation limits

\section{High Phosphate Waste}

Waste shall comply with the following parameters:

Waste with $\left[\mathrm{PO}_{4}^{-3}\right]>0.1 \mathrm{M}$ shall not be mixed with: waste with $\left[\mathrm{Na}^{+}\right]>8 \mathrm{M}$ or neutralized cladding removal waste (NCRW.)

(NCRW is the solids portion of the PUREX Plant neutralized cladding removal waste stream; received in tank farms as a slurry. NCRW solids are classified as TRU waste.)

Source: $\quad$ TWRS F\&R Performance Requirement - High Phosphate Waste

\section{Optional Feeds}

In addition to base feeds, other feed may be considered for processing. This may include additional waste from the currently designated tanks, or waste from other sources. These are considered optional feeds and are not included in the base proposal.

Source: $\quad$ TWRS F\&R Performance Requirement - Optional Feeds

\section{Quantity of Retrieved Tank}

The estimated quantity of retrieved tank waste is $3.1 \mathrm{E}+05$ metric tons, based upon hydraulic retrieval methods.

Source: TWRS F\&R Performance Requirement - Quantity of Retrieved Tank Waste 


\section{Solution Temperature Ranges}

The waste solutions shall be transferred to the store in-process waste system at a maximum waste temperatures of $82{ }^{\circ} \mathrm{C}\left(180^{\circ} \mathrm{F}\right)$, if collected in the AP Tank Farm, $93{ }^{\circ} \mathrm{C}\left(200^{\circ} \mathrm{F}\right)$ if collected in the AN or AW Tank Farms, or $149^{\circ} \mathrm{C}\left(300^{\circ} \mathrm{F}\right)$ if collected in AY or AZ Tank Farms.

The primary tank waste temperature limits for each tank farm are limited to prevent excessive stress to the primary tank and vary depending on the particular tank in question.

Source: $\quad$ TWRS F\&R Performance Requirement - Solution Temperature Ranges

\section{Specific Gravity Limits}

The specific gravity of the solution must be less than $1.41 \mathrm{SpG}$. The specific gravity of the waste is currently used for determination of the potential to cause an accumulation of flammable gases. Transfers will be allowed for SpG of $\leq 1.41$. If the SpG is $>1.41$, then a detailed technical evaluation of potential for flammable gas accumulation in the commingled waste shall be performed.

Source: $\quad$ TWRS F\&R Performance Requirement - Specific Gravity limits

\section{TRU Waste Segregation}

Waste sources shall provide segregated TRU waste, to the extent practicable, to the specified limits below.

Waste sources not classed as high level waste (HLW) with [TRU] $\geq 100 \mathrm{nCi} / \mathrm{g}$ which can be certified to meet the WIPP transuranic waste acceptance criteria shall be transferred to a TRU storage tank. Non-HLW waste sources with [TRU] $<100 \mathrm{nCi} / \mathrm{g}$ shall be transferred to a non-TRU tank or a technical evaluation shall be performed demonstrating that TRU segregation in a TRU storage tank will not be jeopardized.

Source: $\quad$ TWRS F\&R Performance Requirement - TRU Waste Segregation

\section{Transfer System Flush}

Following a waste transfer through a transfer pipeline, the waste generator shall flush the transfer pipeline with a volume of water that is equal to the transfer pipeline volume.

Source: TWRS F\&R Performance Requirement - Transfer System Flush 


\section{Waste Characterization Data}

For waste transfers made within the tank farms and transfers made to the tank farms from other sources, specific characterization data shall be required before the transfer is made. If the characterization data is not available, a sampling event, sampling regime and resultant analysis shall be required. Not every analyte is needed to make a transfer decision for a particular waste stream. Table 7-2 located in WHC-SD-WM-DQO-001, Rev.1, Data Quality Objectives for Tank Farms Waste Compatibility Program, shall be used to establish the specific data needs for the transfer event.

All analytical data generated shall be in accordance with the following:

1. 222S Laboratory Quality Assurance Plan, WHC-SD-CP-QAPP-016, Rev.0

2. The Hanford Quality Assurance Control Manual,WHC-CM-4-2, Release 77.

3. TWRS Characterization Program Quality Assurance Program Plan, WHC-SD-WM-QAPP-025, Rev.0

Source: $\quad$ TWRS F\&R Performance Requirement - Waste Characterization Data

\section{Waste Pumpability}

Waste provided to the transfer managed tank waste system shall comply with the following parameters:

Calculated Reynolds number (NRE) for the waste transfer shall be $\geq 20,000$;

Volume percent solids shall be $\leq 30 \%$.

If these conditions can not be met, technical evaluation shall be required to show that plugging of the line will not occur.

Source: $\quad$ TWRS F\&R Performance Requirement - Waste Pumpability

Issue: Depending on the individual waste source that the manage transfer tank waste system shall interface with, the physical and chemical properties may differ from source to source. Due date is TBD (after contract award).

Required Analysis: An evaluation of the physical and chemical properties of the waste intended for transfer shall be conducted to establish performance requirements. Due date: TBD (after contract award) 


\section{Waste Shipment}

Waste shipped from one field organization to another for treatment, storage or disposal shall be done in accordance with the requirements established by the operations office having responsibility for operations of the receiving facility.

Source: $\quad$ DOE5820.2A, Chapter III, 3.e(1)

\subsection{Waste Acceptance Criteria}

\section{Certification}

Generators of waste shall implement a low-level waste certification program to provide assurance that the waste acceptance criteria for any low-level waste treatment, storage, or disposal facility used by the generator are met. Generators and facilities receiving the waste are jointly responsible for assuring compliance with waste acceptance criteria. Generators are financially responsible for actions required due to nonconformance.

Source: $\quad$ DOE5820.2A, Chapter III, 3.e(2-3)

\section{Issues}

The waste acceptance criteria for storage, treatment, or disposal facilities shall address the following issues:

1. Allowable quantities/concentrations of specific radioisotopes to be handled, processed, stored or disposed of;

2. Criticality safety requirements (waste forms and geometries);

3. Restrictions regarding low-level.waste classified for security reasons;

4. External radiation and internal heat generation;

5. Restrictions on the generation of harmful gases, vapors, or liquids in waste;

6. Chemical and structural stability of waste packages, radiation effects, microbial activity, chemical reactions, and moisture;

7. Restrictions for chelating and complexing agents having the potential for mobilizing radionuclides; and

8. Quantity of free liquids. 
Source: $\quad$ DOE5820.2A, Chapter III, 3.e(5)

\section{Approval}

Generators must receive advance approval from the receiving facility and shall certify prior to shipment that waste meets the receiving facility waste acceptance criteria. The certification program shall be auditable and able to withstand independent review.

Source: DOE5820.2A, Chapter III, 3.g(3)

\subsubsection{Physical Characteristics}

This sub-paragraph describes the requirements for the physical characteristics (e.g., location, land utilization) of the system.

\subsection{Site Boundary}

A site boundary, consistent with the draft Tank Waste Remediation System (TWRS) Environmental Impact Statement (EIS) shall be used. The site boundaries for the EIS will be as follows:

North Columbia River (1/4 mile from bank per REACH EIS);

East Columbia River (1/4 mile from bank per REACH EIS);

South A line running west from the Columbia River, just north of the Washington Public Power Supply System leased are, through the Wye Barricade to Highway 240;

West Highway 240 and Highway 24.

Source: Preliminary TWRS EIS (DOE/EIS - 0189 Draft)

\subsection{Land Use}

\section{Designation of 200 Areas}

The 200 Areas is a limited use area.

Source: DOE/RL 93-08 Hanford Mission Plan

The remediate tank waste (or TWRS) function is a portion of the future Hanford Site waste management activities. The working group recommends that the waste management available land area for the site encompass the "squared off" boundaries of the 200 East and West Areas. The remainder of the Central Plateau that encircles the 200 Areas should be a buffer zone. Further, the working group recommends that waste management, storage, and disposal activities be limited to within the present 200 Area boundaries whenever feasible. 
Source: DOE/EIS-0189, Draft

The operations complex for the TWRS function must be sited on available land. According to the Draft Environmental Impact Statement for the Tank Waste Remediation System (DOE/EIS-0189), about 500 acres will be temporarily committed for the TWRS complex construction and operations. Finally, about 100 acres will be permanently committed for waste management and disposal.

Source: The Future of Hanford: Use and Cleanup - Drummond 1992.

\section{Stakeholder Acceptance}

Consistent with the above information, the Tank.Waste Remediation System Complex Site Evaluation Report (WHC-SD-WM-SE-021, Rev. 0) recommends 200 East Area for the TWRS complex.

Source: WHC-SD-WM-SE-021, Rev.0

Issue: The designation of the 200 Area as a limited use area has not been accepted by all stakeholder groups and may be subject to challenge. The Final Environmental Impact Statement, Disposal of Hanford Defense High-Level, Transuranic and Tank Waste, Hanford Site, Richland Washington (DOE 1987) and accompanying record of decision indicates disposal in the 200 Area the immobilized low-level waste resulting from treatment of double-shell tank waste. No decision was made concerning single-shell tank waste. The Tri-Party Agreement specifies actions which would result in the construction and operation of an Environmental Restoration Disposal Facility (milestone M-70-00) for disposal in the 200 Area of large volumes of hazardous, radioactive, and mixed waste derived from record of decisions for disposition of 100 and 300 Area operable units.

Required Analysis: The supplemental environmental impact statement for the TWRS needs to address disposal in the 200 Area the immobilized low-level waste resulting from treatment of all tank waste.

\subsubsection{System Quality Factors}

The degree of redundancy, reliability, and availability shall correspond to a systematically determined safety classification for all systems, structures, and components.

Source: DOE 6430.1A

\subsection{Reliability}

The design shall provide design features to enhance remote equipment reliability. Evaluation of equipment system failures must be provided to fully define equipment reliability. 
Issue: Develop applicable reliability requirements.

Required Analysis: An approved Reliability, Availability and Maintainability (RAM) analysis must be performed for the design.

\section{Failure Mode and Effects}

The design shall perform a qualitative Failure Mode, and Effects Analysis (FMEA) using MIL-STD-1692A as a guide.

Issue: Develop a qualitative Failure Mode and Effect requirements.

Required Analysis: An approved Failure Mode; and Effects Analysis (FMEA) must be performed during preliminary design and updated during detail design. The approved FMEA will contain a summarization section and recommendations.

\section{Fault Tree Analysis}

A qualitative Fault Tree Analysis (FTA) will be prepared using NUREG-0492 as a guide. This top level analysis shall be tailored to complement the FMEA.

Issue: Develop a qualitative Fault Tree Analysis. From the analysis derived requirements applicable to reliability.

Required Analysis: An approved Fault Tree Analysis (FTA) must be performed during preliminary design.

\subsection{Maintainability}

A schedule and procedure shall be developed for monitoring, surveillance, and calibration checks. The frequency of these activities shall be based on the potential rate of equipment deterioration and the possibility of an environmental or human health incident, assuming that a malfunction from equipment failure or human error is not detected between checks.

Schedules, procedures, and performance requirements shall be documented in the operating and maintenance documentation.

Source: DOE5820.2A, Chapter I, 3.b(4)(e)

DOE5820.2A, Chapter I, 3.c(2)(g)

Each facility shall utilize remote maintenance features and other appropriate techniques to minimize personnel radiation exposure in accordance with DOE 5481.1B.

Source: DOE5820.2A, Chapter I, 3.b(2)(j) 


\subsection{Availability}

The overall availability (e.g., operational availability) shall be sufficient to produce the required total retrieval rates over the designated life of the system. Reliability and maintainability analyses shall be conducted for each major equipment component development item to obtain availability predictions.

Issue 1: Availability requirements need to be prepared for each equipment system, subsystem and component.

Required Analysis: An approved Reliability, Availability, and Maintainability (RAM) analysis must be performed for the retrieval task.

\subsection{Operability and Maintainability}

Four maintenance and operations $(\mathrm{M} \& \mathrm{O})$ categories shall be used to assist in evaluating the design of all facilities. Each facility shall utilize remote maintenance features and other appropriate techniques to minimize personnel radiation exposure in accordance with DOE 5481.1B (Chapter I, 3.b(2)(I)).

Categories $1 \& 2$ - Fully Remote Maintenance and Operation/Remotely Operated and "No" Maintenance. Each system or portion of a system having radiation levels greater than 50 $\mathrm{mrem} / \mathrm{hr}$ contact exposure shall be either (1) remotely maintained and operated or (2) designed to require no maintenance and be remotely operated.

M\&O-1 Definition: Equipment and operational areas falling into this category have radiation levels higher than that which would allow full contact maintenance and operations. Selection of this category should be considered when operational practicalities and economics dictate the need for maintenance and replacement capabilities, while ALARA considerations restrict worker contact. Design for this category should minimize active components. In-cell remote operations may use an in-cell remote crane with an impact wrench, master slave manipulators for light operations in close proximity to shielding windows, and electro-mechanical manipulators. The amount of remote handling equipment is dependent on the operations to be performed.

M\&O-2 Definition: Equipment and operational areas falling into this category have radiation levels higher than that which would allow full contact maintenance and operations. Selection of this category should consider worker exposure as well as operational practicality and economics. Systems and equipment designed for the M\&O category have little external contamination potential because they are typically all-welded systems. Moving parts, wear surfaces, gaskets, and stress cycles (e.g., thermal) are minimized. The corrosion potential for all materials must be low and the flowsheet fully demonstrated with no potential for change. "No maintenance" facilities/areas have little or no remote handling equipment installed. 
Category 3. Limited Contact Maintenance and Operation. Each system or portion of a system having radiation levels greater than $0.1 \mathrm{mrem} / \mathrm{hr}$ to less than or equal to $50 \mathrm{mrem} / \mathrm{hr}$ shall be designed for limited contact maintenance and operation. Designs shall consider remote removal of radiation sources and decontamination prior to personnel entry.

M\&O-3 Definition: "Equipment and operational areas falling into this category have radiation levels higher than that which would allow full contact maintenance and operations. Selection of this category should consider occupational dose, operational practicality and economics which favor design for a limited amount of contact M\&O over design for fully remote $\mathrm{M} \& \mathrm{O}$. Design for this category may include sealed sources in-cell that can be remotely removed with effective contamination control. Personnel entry is then allowed for contact maintenance."

Category 4. Full Contact Maintenance and Operation. Each system or portion of a system having radiation levels less than or equal to $0.1 \mathrm{mrem} / \mathrm{hr}$ shall be designed for full contact maintenance and operation.

M\&O-4: Full Contact Maintenance and Operation (Reference Appendix H). "Equipment and operations falling into this category have levels of radiation and potential for contamination so low that the area may either be considered uncontrolled, such that full-time access is allocated, or controlled, such that a maximum of $40 \mathrm{~h} /$ week of individual worker occupancy is permitted. This corresponds to "uncontrolled radiation areas" and "controlled radiation zone 1 areas". Additionally, levels of contamination are so low as to require no posting, consistent with the criteria presented in DOE N 5480.6.

Source: TWRS Facility Configuration Study, WHC-SD-WM-ES-295, Appendix H, "Maintenance, Operations, and Design Philosophy."

\subsubsection{Environmental Conditions}

New facilities and systems functioning on the Hanford site shall withstand the environmental conditions specified below. Thermal effects of the soil shall be considered for the buried portions of the system.

Ambient Air Temperature

Range: -20 to $120^{\circ} \mathrm{F}$

Rate of increase: $26^{\circ} \mathrm{F}$ per $20 \mathrm{~min}$., maximum

Rate of decrease: $24^{\circ} \mathrm{F}$ per hr., maximum

Relative Humidity: 5 to $100 \%$ (Rate of change is negligible)

Mean annual precipitation: $16 \mathrm{~cm}$ (6.3 in)

Maximum precipitation rate of change: $1.52 \mathrm{~cm} / \mathrm{hr}$. $(0.6 \mathrm{in.} / \mathrm{hr}$.)

Blowing Dust \& Smoke

Visibility: 6 miles or less with sky completely obscured

Frequency: 10 times per year, maximum

Duration: 24 hrs. per occurrence 
Wind Gusts up to 80 miles per hour can be expected on site with the average wind speed in the 200 Area of $7.7 \mathrm{mph}$ in the WNW direction.

Frost Line: 36 in.

Solar Radiation: Frequent exposure due to minimal cloud cover

Additional information on Hanford site weather conditions can be obtained from the Hanford Site vicinity weather bureau.

Source: $\quad$ The Hanford Site Weather Bureau Data is compiled by Battelle Northwest Laboratories- PNL 4622

\subsubsection{Transportability}

Reserved

\subsubsection{Flexibility and Expansion}

Flexibility is a major design requirement for all facilities except those with highly specialized functions. Even in those special facilities, however, the design shall, to the maximum extent practicable, provide sufficient flexibility to accommodate for programmatic changes or operational modifications.

Source: $\quad$ TWRS F\&R Performance Requirement - Design Flexibility DEC1, derived from DOE 6430.1A, 0110-3

\subsubsection{Portability}

Reserved

\subsubsection{Design and Construction}

Designs for new storage and treatment facilities shall meet the requirements of DOE 6430.1, applicable EM Orders and 40 CFR 264.

Source: DOE5820.2A, Chapter I, 3.a(1)(b)

\subsubsection{Materials (Structure, Shielding)}

\subsection{Containment System Design}

\section{Radioactive Material Containment}

All new high-level waste handling, transfer, and storage facilities (e.g., tanks, bins, pipelines, and capsules) shall be doubly contained. 
Source: $\quad$ DOE5820.2A, Chapter I, 3.b(2)(a)

\section{Dangerous Waste Containment}

New tank systems or components shall comply with the standards in WAC 173-303-640, (i.e., structural, tank foundation, secondary containment, etc.)

Source: $\quad$ WAC173-303-640(3)(d)

WAC173-303-640(4)(b-f)

The owner or operator may obtain a variance from the requirements of this subSection if the department finds, as a result of a demonstration by the owner or operator, that in the event of a release that does migrate to ground water or surface water, no substantial present or potential hazard will be posed to human health or the environment. New underground tank systems may not, per a demonstration in accordance with (g)(ii) of this subSection, be exempted from the secondary containment requirements of this Section.

Source: $\quad W A C$ 173-303-640(4) $(g)$

\section{Use of Singly Contained Pipelines}

Singly contained pipelines may be used routinely for liquid waste that has a total radioactivity concentration of less than $0.05 \mathrm{Ci} / \mathrm{gal}\left(4.9 \times 10 / 11 \mathrm{~Bq} / \mathrm{m}^{3}\right)$. They may be used on a temporary basis for higher activity waste, if appropriate design and administrative controls are in place to mitigate adverse effects from a pipeline failure.

Source: $\quad$ DOE5820.2A, Chapter I, 3.b(2)(b)

DOE5820.2A, Chapter I, 3.c(2)(d)

\section{Radioactive Material Leaks}

Secondary containment systems shall be capable of containing liquids that leak into them from the primary system and shall be equipped with transfer capability to retrieve the leaked liquid. Secondary containment systems for solidified high-level waste shall provide for physical isolation of the waste from the environment.

Source: $\quad$ DOE5820.2A, Chapter I, 3.b(2)(d) 


\section{Leaking Waste Storage Systems}

Leaking waste storage systems shall not be used to receive waste unless secondary containment is maintained (e.g., liquid level maintained below leak point) and it can be shown with the support of formal documentation (e.g., Safety Analysis Reports, Operational Safety Requirements, Operating Standards) that temporary operation can be performed without releasing radioactive liquid to the environment.

Source: DOE5820.2A, Chapter I, 3.b(2)(c)

\subsection{Design Load for Facilities}

The TWRS facilities and equipment shall comply: with the DOE Order 5480.28, "Natural Phenomena Hazards Mitigation" policy of the DOE to design, construct, and operate DOE facilities so that workers, the general public, and the environment are protected from the impacts of natural phenomena hazards on DOE facilities. The seismic guidance of the National Earthquake Hazards Reduction Program (NEHRP) contained in the Interagency Committee of Seismic Safety in Construction (ICSSC), reports (RP-1 and RP-3), shall be used.

Source: $\quad$ TWRS F\&R Performance Requirement - Design Loads for Facilities

\subsection{Monitoring and Control System}

\section{Engineering Controls}

Engineering controls shall be incorporated to provide liquid volume inventory data and to prevent spills, leaks, and overflows from tanks or containment systems. Examples are level-sensing devices, liquid level alarms, and maintenance of sufficient freeboard. The high-level waste shall be stored at pressures lower than those of ancillary systems (e.g., cooling water).

Source: DOE5820.2A, Chapter I, 3.b(2)(h)

\section{Power Loss}

Upon loss and subsequent recovery of normal electrical power, high-level waste transfer equipment shall not have the capability to restart without active operator action.

Source: $\quad$ DOE5820.2A, Chapter I, 3.b(2)(k)

DOE5820.2A, Chapter I, 3.c(2)(h) 


\section{Monitoring and Leak Detection}

Monitoring and leak detection capability shall be incorporated in the engineering systems (e.g., liquid level sensing devices and alarms for high-level waste liquid systems) to provide rapid identification of failed containment, and measurement of abnormal temperatures.

Source: $\quad$ DOE5820.2A, Chapter I, 3.b(3)(a-b)

\section{Electrical Monitoring and Leak Detection}

Electrical monitoring and leak detection devices essential to safe operations shall be provided with backup power, as appropriate, to ensure operability under emergency conditions.

Source: $\quad$ DOE5820.2A, Chapter I, 3.b(3)(d)

DOE5820.2A, Chapter I, 3.c(3)(c)

\section{Monitoring and Surveillance}

Monitoring and surveillance capability shall exist to provide liquid volume, waste inventory data, and identification of failed containment.

Source: DOE5820.2A, Chapter I, 3.c(3)(a)

\subsection{Ventilation and filtration Systems}

Where required, ventilation and filtration systems shall be provided to maintain radionuclide releases within the guidelines specified in DOE 5481.1B and applicable EM Orders.

Ventilation systems shall be provided where the possibility exists for generating flammable and explosive mixtures of gases (e.g., hydrogen/air or organic/air).

Source: DOE5820.2A, Chapter I, 3.b(2)(f)

DOE5820.2A, Chapter I, 3.c(2)(e)

\subsection{Groundwater Monitoring System}

\section{Monitoring Wells}

A system of ground water or vadose zone monitoring wells meeting the Resource Conservation and Recovery Act requirements per 40 CFR 264 shall be installed, as a minimum, around clusters of liquid waste storage tanks.

Source: $\quad$ DOE5820.2A, Chapter I, 3.b(3)(f)

DOE5820.2A, Chapter I, 3.c(3)(d)

WAC173-303-645(8)(a-c) 


\section{Well Drilling}

Monitoring wells and other bore holes shall be appropriately sealed after use so as to not provide a pathway for contamination to the ground-water.

Source: WAC 173-160

\section{Monitoring for Indicator Parameters}

The owner or operator must monitor for indicator parameters (e.g., $\mathrm{pH}$, specific conductance, total organic carbon (TOC), total organic halogen (TOX), or heavy metals), waste constituents, or reaction products that provide a reliable indication of the presence of dangerous constituents in ground water.

Source: WAC173-303-645(9)(a-c)

\subsection{Surface Water Monitoring System}

Surface water systems associated with the high-level waste storage area shall be monitored according to applicable National Pollution Discharge Elimination System permits and EM Order requirements.

Source: DOE5820.2A, Chapter I, 3.b(3)(e)

WAC.173.303.640.7(a-c)

\subsection{Remediation of Leaks}

\section{Tank or Secondary Containment System}

A tank or secondary containment system from which there has been a leak or a spill to the surrounding soil, or which is otherwise unfit for use, shall be removed from service until conditions can be evaluated fully.

Source: $\quad$ DOE5820.2A, Chapter I, 3.b(4)(a)

\section{Release of Radioactive Materials}

Upon detection of released radioactive materials, steps shall be taken to prevent further migration of the release to soil or surface water. Major contamination in the soil shall be removed or stabilized unless compliance with this requirement would cause greater harm to human health or the environment.

Source: $\quad$ DOE5820.2A, Chapter I, 3.b(4)(b) 


\section{Discharge of Other Liquids}

Liquid discharges, even though uncontaminated, are prohibited in inactive release areas to prevent the further spread of radionuclides previously deposited.

Source: $\quad$ DOE 5400.5, Chapter II, 3.c(2)

\section{Integrity of System}

If a release results from a spill and the integrity of the system is not damaged, the system may be returned to service as soon as action to correct the condition is completed.

Souree: $\quad$ DOE5820.2A, Chapter I, 3.b(4)(c)

\section{Contingency Plan}

A contingency action plan shall be maintained to respond to spills or leaks and other credible emergencies as identified in the Safety Analysis Reports. Leak mitigation (see paragraph $3 b(4)(b)$ ). For emergency situations involving pumpable liquid in singly contained tanks, appropriate equipment (e.g., pumps) shall be maintained to provide removal of liquid.

Source: $\quad$ DOE5820.2A, Chapter I, 3.c(4)

DOE5820.2A, Chapter I, 3.c(2)(h)

\section{Notifications}

Any release to the environment, except as provided in(d)(ii) of this subSection, must be reported to the department within twenty-four hours of its detection. Any release above the "reportable quantity" must also be reported to the National Response Center pursuant to 40 CFR Part 302.

A leak or spill of dangerous waste is exempted from the requirements of (d) of this subSection if it is: (A) Less than or equal to a quantity of one pound, or the "Reportable Quantity" (RQ) established in 40 CFR Part 302, whichever is less; and (B) Immediately contained and cleaned-up. (iii) Within thirty days of detection of a release to the environment, a report containing the following information must be submitted to the department: (A) Likely route of migration of the release; (B) Characteristics of the surrounding soil (soil composition, geology, hydrogeology, climate); (C) Results of any monitoring or sampling conducted in connection with the release (if available). If sampling or monitoring data relating to the release are not available within thirty days, these data must be submitted to the department as soon as they become available; (D) Proximity to down gradient drinking water, surface water, and populated areas; and (E) Description of response actions taken or planned.

Source: $\quad$ WAC $173-303-640(7)(d)$ 


\subsection{Corrosion Prevention and Control}

\section{External Corrosion Protection}

For new tank systems or components in which the external shell of a metal tank or any external metal component of the tank system will be in contact with the soil or with water, a determination by a corrosion expert will determine the factors affecting the potential for corrosion and the type and degree of external corrosion protection that are needed to ensure the integrity of the tank system during its use.

Source: $\quad$ DOE5820.2A, Chapter I, 3.c(3)(b)

WAC173-303-640.3.a.iii

WAC173-303-640.3.g

\section{Cathodic Corrosion Protection}

Facilities using cathodic corrosion protection systems shall include engineered features that protect against abnormal conditions such as stray currents or system failure. The cathodic protection systems shall be calibrated annually, and all sources of impressed current shall be inspected and/or tested at least every other month.

Source: $\quad$ DOE5820.2A, Chapter I, 3.b(2)(g)

\section{Assessment of System Integrity}

A method for periodically assessing waste storage system integrity (e.g., coupons for corrosion testing, photographic and periscopic inspections, leak detectors, liquid level devices) shall be established, documented, and reported as required in the Waste Management Plan.

\subsection{Shielding Criteria}

Guidelines for radiological design are provided in WHC-SD-GN-DGS-30011, Radiological Design Guide. The shielding design criteria in WHC-SD-GN-DGS-30011, Section 7.0, shall be used to determine the shielding requirements of different areas in the facility. Shielding shall be designed to limit the total whole body dose to less than $5 \mathrm{mSv}$ per year.

Source: $\quad$ TWRS F\&R Performance Requirement - Shielding Criteria

\subsubsection{Radiation}

\subsection{DOE Sponsored Radiological Requirements}

The Radiological Health and Safety Policy provides the general framework for the conduct of radiological control activities throughout the DOE complex. Below the policy statement are both regulatory and contractual systems of basic requirements established through $10 \mathrm{CFR}$ 
835, which is enforced through a regulatory system established in 10 CFR 820, and DOE Order 5480.11, which is enforced through contractual commitments. The requirements of the Rule are augmented by complementary guidance provided in Implementation Guides while the requirements of the Order are augmented by complementary guidance provided in the DOE Radiological Control Manual.

The Hanford Site Radiological Control Manual (HSRCM) has been developed through a cooperative effort between the DOE Richland Operations Office (RL) and the Hanford contractors. As required by Article 114.1, the HSRCM has been approved by the senior site executives of the Hanford contractors and provides the basis for consistent and uniform implementation of radiological control requirements for the Hanford Site.

Source: $\quad$ PART 1 Department of Energy (DOE) Radiological Control Manual

\subsection{Maximum Contaminant Levels}

Maximum contaminant levels for ${ }^{226} \mathrm{Ra},{ }^{228} \mathrm{Ra}$, and gross alpha particle radioactivity in community water systems. The following are the maximum contaminant levels for ${ }^{226} \mathrm{Ra}$, ${ }^{228} \mathrm{Ra}$, and gross alpha particle radioactivity: (a) Combined ${ }^{226} \mathrm{Ra}$ and ${ }^{228} \mathrm{Ra}-5 \mathrm{pCi} / \mathrm{l}$. (b) gross alpha particle activity (including ${ }^{226} \mathrm{Ra}$ but excluding radon and uranium) $-15 \mathrm{pCi} / \mathrm{L}$.

Maximum contaminant levels for beta particle and photon radioactivity from man-made radionuclides in community water systems. (a) The average annual concentration of beta particle and photon radioactivity from man-made radionuclides in drinking water shall not produce an annual dose equivalent to the total body or any internal organ greater than 4 mrem/year.

Source: $\quad 40$ CFR 141 - per DOE 5400.5, Chapter II, 1.d(3)

The maximum permissible concentration of radionuclides in gaseous emissions from the ventilation system shall be:

1. Annual Average Concentrations: Not to exceed 1 times the DCG-public value of WHC-CM-7-5, Appendix $\mathrm{C}$, at point of release.*

2. Weekly Average Concentrations: Not to exceed 10 times the annual average ACV concentrations for that stack at point of release.*

3. Instantaneous Concentration: Not to exceed 5,000 times the DCG-public value of WHC-CM-7-5, Appendix C, averaged over any four hour period at point of release. 
a. Exceptions Stacks 296-A-17, 296-A-27, 296-A-29: Not to exceed 10 times the DCG value at point of release.* (For other exceptions see compliance plans to WHC-CM-7-5.)

* Except for krypton-85: Not to exceed a combined release of $4 \mathrm{E}+06 \mathrm{Ci} / \mathrm{yr}$.

Source: $\quad$ OSD-T-151-0007, 7.3.1.E

\subsection{Non-DOE Sponsored Radiological Requirements}

For any Non-DOE sponsored work 10 CFR 20.1201, 10 CFR 20.1301, 10 CFR 20.1601, 10 CFR 20.1602, 10 CFR 20.1603, 10 CFR 20.1701, 10 CFR 20.1702, 40 CFR 191, 40 CFR 192, and 40 CFR 193 are applicable.

Source: TWRS F\&R Performance Requirement - Non-DOE Sponsored Radiological Requirements

\subsection{Accidental Public Exposure}

DOE facilities will be designed, constructed, operated, and decommissioned to assure the protection of the public, workers, and the environment.

The risk to an average individual in the vicinity of a DOE nuclear facility for prompt fatalities that might result from accidents should not exceed one tenth of one percent $(0.1 \%)$ of the sum of prompt fatalities resulting from other accidents to which members of the population are generally exposed. For evaluation purposes, individuals are assumed to be located within one mile of the site boundary.

DOE nuclear facilities and activities shall be designed, constructed, operated, and decommissioned with: (a) appropriate barriers to prevent or minimize potential radioactive releases; (b) engineered safety features to minimize potential releases; and (c) procedural controls to mitigate the effects of potential releases. These goals shall be addressed for both new and existing facilities.

Source: $\quad$ Nuclear Safety Policy, SEN-35-91

\subsubsection{Name Plates and Product Markings}

Each package of waste must comply with the labeling requirements of DOE 1540.1 .

Source: $\quad$ DOE5820.2A, Chapter III, 3.g(4) 


\subsubsection{Workmanship}

See Section 1.4.

\subsubsection{Interchangeability}

The Retrieval Projects shall include interchangeability factors. These requirements are TBD. Interchangeability is required to allow, as much as is practical, for temporary use of parts/equipment until a replacement is procured, e.g., use of a pipe fitting or electrical fitting which may suffice until its replacement is obtained.

\subsubsection{Safety}

\subsection{Safety Analysis}

A contractor, as designated in writing by the PSO, who is responsible for the design, construction, or operation of DOE nuclear facilities shall be required to perform a safety analysis that develops and evaluates the adequacy of the safety basis for each such facility.

Source: $\quad$ DOE5480.23

Storage and transfer operations shall be conducted within the limits defined in the Safety Analysis Reports according to DOE 5481.1B.

Source: $\quad$ DOE5820.2A, Chapter I, 3.c(2)(b)

\subsection{Unreviewed safety Questions}

Perform all safety evaluations to determine whether a situation involves USQ.Prior to implementation of a proposed action, obtain PSO approval for situations determined to involve a USQ or a Technical Safety Requirements (TSR) change; and develop and implement procedures to govern the need for, and the performance of, safety evaluations under this Section.

Source: $\quad$ DOE5480.21.10.a

\subsection{Technical Safety Requirements}

In accordance with this Order, a contractor responsible for the operation of a DOE nuclear facility shall prepare and submit the Technical Safety Requirements to the PSO for approval for the facility. The contractor shall operate the facility in accordance with the Technical Safety Requirements as approved by the PSO including any modification by the PSO.

Source: DOE5480.22.9.a 


\subsection{Environmental, Safety and Health}

The Purpose of this Order is to specify and provide requirements for the application of the mandatory environmental protection, safety, and health (ES\&H) standards applicable to all Department of Energy (DOE) and DOE contractor operations, to provide a listing of reference ES\&H standards; and to identify the sources of the mandatory and reference ES\&H standards. This Order shall be followed during facility design, construction, operation, modification, and decommissioning.

\section{Source: DOE5480.4}

\subsection{Environmental Surveillance}

Environmental surveillance shall be conducted to monitor the effects, if any, of DOE activities on onsite and offsite environmental and natural resources. An environmental surveillance screening program shall be undertaken at DOE sites to determine the need for a permanent surveillance program. Environmental surveillance shall be designed to satisfy one or more of the following program objectives: (a) Verify compliance with applicable environmental laws and regulations; (b) Verify compliance with environmental commitments made in Environmental Impact Statements, Environmental Assessments, Safety Analysis Reports, or other official DOE documents; (c) Characterize and define trends in the physical, chemical and biological condition of environmental media; (d) Establish baselines of environmental quality; (e) Provide a continuing assessment of pollution abatement programs; (f) Identify and quantify new or existing environmental quality problems.

Environmental surveillance programs and components should be determined on a site-specific basis by the field organization. Programs should reflect facility characteristics, applicable regulations, hazard potential, quantities and concentrations of materials released, the extent and use of affected air, land, and water, and specific local public interest or concern. Surveillance programs are likely to include one or more of the following: (a) Monitoring stations; (b) Sampling and analysis; and (c) Monitoring data record keeping.

Source: DOE5400.1, Chapter IV, 5.b

1. Each operational or non-operational low-level waste treatment, storage, and disposal facility shall be monitored by an environmental monitoring program that conforms with DOE 5484.1 [DOE 5400.l, Chapter IV, 5.b] and, at a minimum, meet the requirements of paragraph $3 \mathrm{~K}(2)$ through $3 \mathrm{~K}(4)$.

2. The environmental monitoring program shall be designed to measure: (a) operational effluent releases; (b) migration of radionuclides; (c) disposal unit subsidence; and (d) changes in disposal facility and disposal site parameters which may affect long-term site performance. 
3. Based on the characteristics of the facility being monitored, the environmental monitoring program may include, but not necessarily be limited to, monitoring surface soil, air, surface water, and, in the subsurface, soil and water, both in the saturated and the unsaturated zones.

4. The monitoring program shall be capable of detecting changing trends in performance sufficiently in advance to allow application of any necessary corrective action prior to exceeding performance objectives. The monitoring program shall be able to ascertain whether or not effluents from each treatment, storage, or disposal facility or disposal site meet the requirements of applicable EH Orders.

Source: $\quad$ DOE5820.2A, Chapter III, 3.k

\subsection{Fire Protection}

\section{Fire Protection Program}

In accordance with this Order and, as required by the PSO or the Heads of Field Organizations and directed by the Contracting Officer, contractors shall be required to provide and maintain a level of fire protection, and a system to ensure that the requirements of the DOE fire protection program are documented and incorporated in the plans and specifications for all new facilities and for major modifications of existing facilities.

\section{Source: $\quad$ DOE5480.7.A.8.i}

\section{Uniform Fire Codes}

Containers holding reactive waste exhibiting a characteristic specified in WAC 173-303-090 (7)(a)(vi), (vii) or (viii) must be stored in a manner equivalent to the Uniform Fire Code's "American Table of Distances for Storage of Explosives," Table 77-201, 1979 edition or the version adopted by the local fire district.

Source: WAC173-303-630(8)

\subsection{ALARA}

In accordance with the recommendations of the Environmental Protection Agency, formerly the Federal Radiation Council, approved by the president of the United States of America, persons engaged in activities under licenses issued by the Washington state department of health pursuant to the Atomic Energy Act of 1954, as amended, shall, in addition to complying with the requirements set forth in chapter 246-221 WAC, make every reasonable effort to maintain radiation exposures, and releases of radioactive materials in effluents to unrestricted areas, as low as is reasonably achievable. 
Source: WAC.246-220-007

The cost/benefit analysis used by Westinghouse Hanford Company is based on guidance provided in Health Physics Manual of Good Practices for Reducing Radiation Exposures to Levels That Are As Low As Reasonably Achievable, PNL-6577. This document is cited in DOE Order 5480.11, Radiation Protection for Occupational Workers as providing useful information for implementing the requirements of the order.

Source: $\quad$ TWRS F\&R Performance Requirement - ALARA

\subsection{Design for Safety}

\section{Design Objectives}

Design objectives for new facilities will assure protection of the public and operating personnel from hazards associated with normal high-level waste operations, accident conditions, and the effects of natural phenomena. Other objectives are compliance with DOE policies regarding nuclear safety, quality assurance, fire protection, pollution control, and safeguards and security protection for high-level waste and protection of essential operations from the effects of potential accidents.

Source: $\quad$ DOE5820.2A, Chapter I, 3.a(1)(a)

\section{Preparation of Safety Analysis Reports}

Uniform requirements for the preparation of safety analysis reports for high-level waste operations, detailed in DOE 5481.1B, include the review of existing operational facilities based on current technical criteria. When hazards are identified that should be eliminated, controlled, or mitigated, appropriate upgrading, actions in accordance with paragraph $3 \mathrm{a}(1)$ above, shall be identified and implemented according to the requirements of DOE 5481.1B.

Source: $\quad$ DOE5820.2A, Chapter I, 3.a(2)

\subsection{Worker Occupational Safety}

TWRS activities shall conform to 29 CFR 1910 and DOE 5483.1a Occupational Safety and Health Administration (OSHA) Program at Government owned contractor operated facilities.

Source: TWRS F\&R Performance Requirement - Worker Occupational Safety 


\subsection{Maintenance Management Program}

The Maintenance management program for all DOE property be consistent with DOE 4330.4B Order and that all DOE property be maintained in a manner which promotes operational safety, worker health, environmental protection and compliance, property preservation, and cost-effectiveness while meeting the programmatic mission.

Source: DOE4330.4B Maintenance Management Program

\subsubsection{Human Engineering}

Human Factors criteria shall apply to new construction and to retrofitting of existing facilities.

Source: $\quad$ TWRS F\&R Performance Requirement - Human Factors

\subsubsection{Nuclear Control}

\subsection{Criticality}

\section{Criticality Safety Program}

The contractor criticality safety program for nuclear facilities shall include the requirements of, and be in accordance with DOE 5480.24.

\section{Source: $\quad$ DOE 5480.24 .7}

The criticality safety program defined herein applies to all storing, retrieving, processing, transfer operations, transport and storage activities and waste form operations involving fissionable material quantities in excess of $3 \%$ of a minimum critical mass.

Source: $\quad$ TWRS F\&R Performance Requirement - Criticality

\section{Nuclear Criticality Safety Considerations}

Nuclear criticality safety considerations and controls shall be evaluated for normal operations and, before any significant operational changes are made, to protect against an uncontrolled nuclear criticality incident (e.g., dissolution of sludges for removal from tank).

Source: DOE5820.2A, Chapter I, 3.b(2)(i)

DOE5820.2A, Chapter I, 3.c(2)(f) 


\subsection{Safety/Hazard Classification for Nuclear facilities and Operations}

Facilities that treat, store or dispose of hazardous (dangerous) waste and mixed waste (containing both hazardous and radioactive waste components) shall conform to DOE Order 5820.2A. Hazardous waste is regulated in accordance with the Resource Conservation and Recovery Act (RCRA) and the Washington Administrative Code (WAC) 173-303, Dangerous Waste Regulations.

Source: $\quad$ TWRS F\&R Performance Requirement- Hazardous Waste Management

Dangerous wastes or treatment reagents must not be placed in a tank system if they could cause the tank, its ancillary equipment, or the containment system to rupture, leak, corrode, or otherwise fail.

Source: WAC173-303-640(5)

\subsubsection{System Security}

Safeguard and security system shall meet the requirements of DOE 470.1. Detailed requirements for personnel security activities, protection operations, information security, and materials control and accountability are set forth in the Orders listed below:

1. Program Management, DOE 0470 series

2. Personnel Security, DOE 0472 series

3. Protection Operations, DOE 5632 and DOE 0473 series

4. Materials Control and Accountability, DOE 5632 and DOE 0474

5. Information Security, DOE 5639 and DOE 0471 series

Source: $\quad$ DOE 470.1

1.3.3.10 Government Furnished Property Capacity

Reserved

\subsubsection{Computer Resource Reserve Capacity}

Reserved

\subsubsection{Documentation}

\section{Records, Documents, and Document Control}

Records, documents, and document control pertinent to design functions shall be in accordance with ASME-NQA-1-1994-IA, DOE 5500.7b, DOE-5480.CM, and ANSI/ANS-3.2-88. 
Source: TWRS F\&R Performance Requirement - Documentation

\section{Response Procedures}

Each high-level waste facility shall have response procedures for credible emergencies, as identified in the Safety Analysis Reports.

Source: DOE5820.2A, Chapter I, 3.b(4)(f)

\section{Record Keeping System}

Each field organization shall develop and maintain a record keeping system that records the following: a historical record of waste generated, treated, stored, shipped, disposed of, or both, at the facilities under its cognizance.

Source: DOE5820.2A, Chapter III, 3.m(1)

\section{Waste Manifests Records}

Records shall be kept and accompany each waste package from generator through final disposal. The manifest shall contain data necessary to document the proper classification, and assist in determining proper treatment, storage, and disposal of the waste. Waste manifests will be kept as permanent records.

Source: DOE5820.2A, Chapter III, 3.m(2)

\section{Waste Characteristics and Compatibility Information}

Waste characteristics and compatibility information shall be documented in a safety analysis report (see DOE 5481.1B) and be used as a basis for designing new facilities.

Source: DOE5820.2A, Chapter I, 3.b(1)(b)

\section{Operational Records}

Operational records (e.g., facility design drawings and modifications, characterization data on contamination levels, prior decontamination activities, and incident reports required by DOE Orders) for all contaminated facilities shall be maintained by the cognizant field organization for use in preparing decommissioning plans.

Source: DOE5820.2A, Chapter V, 3.a(2) 


\section{Handling Procedures}

The owner or operator of a new tank system must ensure that proper handling procedures are adhered to in order to prevent damage to the system during installation.

Source: $\quad$ WAC-173-303-640. 3c

\section{Conduct of Operations}

It is the policy of the Department that the conduct of operations at DOE facilities be managed with a consistent and auditable set of requirements, standards, and responsibilities.

Source: $\quad$ DOE5480.19

\subsubsection{Personnel and Training}

Operator training and qualification standards shall be developed and an up-to-date record of training status shall be maintained.

Source: $\quad$ DOE5820.2A, Chapter I, 3.b(5) DOE5820.2A, Chapter I, 3.c(5)

The system shall be designed for operation by personnel possessing qualifications in accordance with DOE 5480.20 Chapter IV, and trained in accordance with Chapter I.

Source: $\quad$ TWRS F\&R Performance Requirement - Personnel and Training

\subsubsection{Precedence}

The hierarchical relationship among requirements specified in Section 3.0 is provided in this Section. The hierarchical relationship among requirements specified in Section 3.0 is as follows, except in those instances where Washington state has been granted regulatory authority by the U.S Government:

- Federal Laws (e.g., Code of Federal Regulations)

- $\quad$ Revised Code of Washington (RCW) as specified in Washington Administrative Code 
- Local Ordinances

- U.S. Department of Energy Orders and Secretary of Energy directives

- National Consensus Codes and Standards

\subsubsection{Qualification}

Reserved

\subsubsection{Standard Sample}

Reserved

\section{4}

\section{QUALITY ASSURANCE PROVISIONS}

This function shall adhere to the applicable requirements of 10 CFR 830, "Nuclear Safety Management, Subpart A, General Provisions, Section 830.120, Quality Assurance Requirements," Code of Federal Regulations. In accordance with these requirements, the project shall develop a project specific Quality Assurance Program Plan (QAPP) encompassing the following program elements as applicable to the project:

Program

Personnel Training and Qualifications

Quality Improvement

Documents and Records

Work Processes

Design

Procurement

Inspection And Acceptance Testing

Management Assessment

Independent Assessment.

The QAPP shall be submitted to DOE for approval.

All subcontractors providing services for the function, such as: architect and engineering (A-E) services, Construction Management (CM) services, and testing services in support of technology development shall be required to have or develop a QAPP compatible with the requirements of 10 CFR 830.120 , as specific to the subcontractors area of responsibility. As 
long as the program is compatible with the above referenced requirements, it's bases can be founded in existing consensus standards, such as: ASME NQA-1, 10 CFR 50 Appendix B, and the ISO 9000 series. All subcontractor QAPPs shall be submitted to the WHC for review and concurrence.

Source: $\quad$ TWRS F\&R Performance Requirement - Quality Assurance Plan

Consistent with DOE Order $-5700.6 \mathrm{~B}$, high-level waste operations shall be conducted in accordance with applicable requirements of the American National Standards Institute/American Society of Mechanical Engineers Nuclear Quality Assurance-1 and other appropriate national consensus standards. (See Attachment 1, page 5, paragraph 48).

Source: DOE5820.2A, Chapter I, 3.b(6)

DOE5820.2A, Chapter I, 3.c(6)

\subsubsection{Responsibility for Inspection}

At least weekly, the owner or operator must inspect areas where containers are stored, looking for leaking containers and for deterioration of containers and the containment system caused by corrosion, deterioration, or other factors.

Source: WAC173-303-630(6)

The owner or operator must develop and follow a schedule and procedure for inspecting overfill controls. (b) The owner or operator must inspect at least once each operating day: (i) Above ground portions of the tank system, if any, to detect corrosion or releases of waste;

(ii) Data gathered from monitoring any leak detection equipment (e.g., pressure or temperature gauges, monitoring wells) to ensure that the tank system is being operated according to its design; and (iii) The construction materials and the area immediately surrounding the externally accessible portion of the tank system, including the secondary containment system (e.g., dikes) to detect erosion or signs of releases of dangerous waste (e.g., wet spots, dead vegetation).

Source: $\quad$ WAC 173-303-640(6)(a)

\subsubsection{Special Tests and Examinations}

Table 1-2 correlates the requirements of Section 3.3 with the method to be used to comply with the requirements. Documentation of compliance will be accomplished through the use of detailed procedures to be developed and performed on all procured, constructed, and developed equipment, structures, and software.

The methods of compliance to be used are: 
A. Analysis. Analysis is the process needed to verify a requirement by rational thinking, tradeoff studies, modeling, and processing test data and accumulated results to reach a conclusion. Analysis involves the processing of accumulated results and conclusions, intended to provide proof that verification of a requirement has been accomplished. The analytical results may be comprised of a compilation or interpretation of existing information or derived from lower level examinations, tests, demonstrations, or analyses.

B. Examination. Examination is the process of investigating a product to verify that required features are incorporated. Examination consists of investigation, without the use of special laboratory appliances, procedures, supplies, or services, to determine conformance to those specified requirements which can be determined by such investigations. Examination is generally nondestructive and includes, but is not limited to, visual, auditory, olfactory, tactile, and other investigations; simple physical manipulation; gauging; and measurement.

C. Test. Test is the quantitative process whereby data is collected over a specified time period, under controlled conditions, in order to document the as-built performance of a product. A test denotes the determination of the properties or elements of items (or components thereof) by technical means, including functional operation, the application of established principles and procedures and the collection of quantitative data. The analysis of data derived from testing is an integral part of the method.

D. Demonstration. Demonstration is the qualitative process of exercising a product to verify its operability, where data may or may not be collected. Demonstration differs from test by directness of approach in the verification of a requirement and is accomplished without the use of instrumentation or special equipment. Thus, operation of a representative item in or near its use environment would be defined as a Demonstration rather than a Test.

Demonstration attempts to verify, qualitatively, the performance of a function, where as Test involves verifying performance within a specific range of measurement.

When more than one method of compliance is marked in Table 3-4, compliance must be verified by one or more of the methods marked.

Table 1-2, Verification Matrix. ( 5 sheets)

\begin{tabular}{|c|c|c|c|c|c|c|}
\hline Sectom & Titie & $\mu^{2}$ & 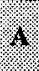 & is. & \% & 19 \\
\hline 1.3.2.1 & Performance Characteristics & $\mathrm{X}$ & & & & \\
\hline 1.3 .2 .1 .1 & Waste Minimization/Volume Reduction & & $\mathrm{X}$ & & & \\
\hline 1.3.2.1.2 & Waste Segregation & & & & $\mathrm{X}$ & \\
\hline 1.3 .2 .2 & System Capability Relationships & $\mathrm{X}$ & & & & \\
\hline 1.3 .2 .2 .1 & Definition of Operating Modes & $\mathrm{X}$ & & & & \\
\hline 1.3.2.2.1.1 & Start-up/Testing & & & & $\mathrm{X}$ & \\
\hline 1.3 .2 .2 .1 .2 & Watch List tanks & & & & $\mathrm{X}$ & \\
\hline
\end{tabular}


Table 1-2. Verification Matrix. (5 sheets)

\begin{tabular}{|c|c|c|c|c|c|c|}
\hline 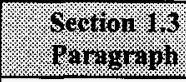 & (1) & Wa & 1 & e. & . 1 & 19 \\
\hline 1.3 .2 .2 .1 .3 & Decontamination and Decommissioning & $\mathrm{X}$ & & & & \\
\hline 1.3.2.2.2 & Operating Modes Schedule & & $\mathrm{X}$ & & & \\
\hline 1.3.2.2.2.1 & Estimated TWRS Schedule & & $\mathrm{X}$ & & & \\
\hline 1.3.2.2.2.2 & Annual Forecast & & $\mathrm{X}$ & & & \\
\hline 1.3 .2 .3 & External Interface Requirements & $\mathrm{X}$ & & & & \\
\hline 1.3 .2 .3 .1 & Tank Waste for Retrieval (Input) & & $\mathrm{X}$ & & & \\
\hline 1.3 .2 .3 .2 & $\begin{array}{l}\text { Raw Materials for Retrieve Tank Waste } \\
\text { (Input) }\end{array}$ & & $\mathrm{x}$ & & & \\
\hline 1.3.2.3.2.1 & Raw Material Requirement & & & & $\mathrm{X}$ & \\
\hline 1.3.2.3.3 & Recycled Water For Retrieval (Input) & & & & $\mathrm{X}$ & \\
\hline 1.3 .2 .3 .3 .1 & Recycled Water Requirements & & & & $\mathrm{X}$ & \\
\hline 1.3 .2 .3 .4 & $\begin{array}{l}\text { Sanitary Waste Services for Retrieve } \\
\text { Tank Waste (Input) }\end{array}$ & & & & & $\mathrm{X}$ \\
\hline 1.3 .2 .3 .5 & Tank Operations Information (Input) & & $\mathrm{X}$ & & $\mathrm{X}$ & \\
\hline 1.3.2.3.6 & $\begin{array}{l}\text { Tank Waste Characterization Information } \\
\text { (Input) }\end{array}$ & & $\mathrm{X}$ & & $\mathrm{X}$ & \\
\hline 1.3.2.3.6.1 & Tank Characterization Requirements & & $\mathrm{X}$ & & $\mathrm{X}$ & \\
\hline 1.3.2.3.7 & Tank Farm Geological data & & $\mathrm{x}$ & & & \\
\hline 1.3.2.3.8 & $\begin{array}{l}\text { Retrieve Tank Waste Ancillary } \\
\text { Equipment and Systems (Output) }\end{array}$ & & & & $\mathrm{X}$ & \\
\hline 1.3 .2 .3 .8 .1 & $\begin{array}{l}\text { Retrieve Tank Waste Ancillary. } \\
\text { Equipment and Systems Requirements }\end{array}$ & & $\mathrm{X}$ & $\mathrm{X}$ & $\mathrm{X}$ & \\
\hline 1.3 .2 .3 .9 & $\begin{array}{l}\text { Retrieve Tank Waste Characterization } \\
\text { (Output) }\end{array}$ & & & & $\mathrm{X}$ & \\
\hline 1.3 .2 .3 .9 .1 & $\begin{array}{l}\text { Retrieve Tank Waste Characterization } \\
\text { Requirements }\end{array}$ & & $\mathrm{X}$ & & $\mathrm{X}$ & \\
\hline 1.3 .2 .3 .10 & $\begin{array}{l}\text { Retrieve Tank Waste Excess Facilities } \\
\text { (Output) }\end{array}$ & $\mathrm{X}$ & & & & \\
\hline 1.3 .2 .3 .10 .1 & $\begin{array}{l}\text { Tank Waste Excess Facilities } \\
\text { Requirements }\end{array}$ & & $\mathrm{X}$ & & & \\
\hline 1.3.2.3.11 & Retrieve Tank Waste Garbage (Output) & & & & $\mathrm{X}$ & \\
\hline 1.3 .2 .3 .12 & $\begin{array}{l}\text { Retrieve Tank Waste Hazardous Waste } \\
\text { (Output) }\end{array}$ & & & & $\mathrm{X}$ & \\
\hline
\end{tabular}


Table 1-2. Verification Matrix. (5 sheets)

\begin{tabular}{|c|c|c|c|c|c|c|}
\hline $\begin{array}{l}\text { Section } / 3 \\
\text { Partgraph }\end{array}$ & tilio & $1 \%$ & 14 & 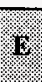 & T & 18 \\
\hline 1.3 .2 .3 .12 .1 & $\begin{array}{l}\text { Retrieve Tank Waste Hazardous Waste } \\
\text { Requirements }\end{array}$ & & $\mathrm{X}$ & & $\mathrm{X}$ & $\mathrm{X}$ \\
\hline 1.3 .2 .3 .13 & $\begin{array}{l}\text { Retrieve Tank Waste Prepared Solid } \\
\text { Waste (Output) }\end{array}$ & & $\mathrm{X}$ & & & \\
\hline 1.3.2.3.13.1 & $\begin{array}{l}\text { Tank Retrieval Prepared Solid Waste } \\
\text { Requirements }\end{array}$ & & & & $\mathrm{X}$ & \\
\hline 1.3 .2 .3 .14 & $\begin{array}{l}\text { Retrieve Tank Waste Transferrable } \\
\text { Resources (Output) }\end{array}$ & & $\mathrm{X}$ & & $\mathrm{X}$ & \\
\hline 1.3 .2 .3 .15 & $\begin{array}{l}\text { Retrieve Tank Waste Treated Gaseous } \\
\text { Effluents (Output) }\end{array}$ & & & & $\mathrm{X}$ & \\
\hline 1.3 .2 .3 .15 .1 & $\begin{array}{l}\text { Tank Waste Treated Gaseous Effluents } \\
\text { Requirements }\end{array}$ & & & & $\mathrm{X}$ & \\
\hline 1.3 .2 .3 .16 & $\begin{array}{l}\text { Retrieve Tank Waste Treated Liquid } \\
\text { Effluents (Output) }\end{array}$ & & & & $\mathrm{X}$ & \\
\hline 1.3 .2 .3 .16 .1 & $\begin{array}{l}\text { Tank Waste Treated Liquid Effluents } \\
\text { Requirements }\end{array}$ & & & & $\mathrm{X}$ & \\
\hline 1.3.2.3.17 & $\begin{array}{l}\text { Retrieve Tank Waste Untreated Liquid } \\
\text { Effluents (Output) }\end{array}$ & & & & $\mathrm{X}$ & \\
\hline 1.3.2.3.17.1 & $\begin{array}{l}\text { Tank Waste Untreated Liquid Effluents } \\
\text { Requirements }\end{array}$ & & & & $\mathrm{X}$ & \\
\hline 1.3.2.3.18 & Retrieved Tank Waste (Output) & & $\mathrm{X}$ & & $\mathrm{X}$ & \\
\hline 1.3.2.3.18.1 & Retrieved Tank Waste Requirements & & $\mathrm{X}$ & $\mathrm{X}$ & $\mathrm{X}$ & \\
\hline 1.3 .2 .3 .18 .2 & Waste Acceptance Criteria & & $\mathrm{X}$ & & & \\
\hline 1.3 .2 .4 & Physical Characteristics & $\mathrm{X}$ & & & - & \\
\hline 1.3.2.4.1 & \begin{tabular}{|l|} 
Site Boundary \\
\end{tabular} & & $\mathrm{X}$ & & & \\
\hline 1.3.2.4.2 & Land Use & & $\mathrm{X}$ & $\mathrm{X}$ & & \\
\hline 1.3 .2 .5 & System Quality Factors & $\mathrm{X}$ & & & & \\
\hline 1.3 .2 .5 .1 & Reliability & & & $\mathrm{X}$ & $\mathrm{X}$ & \\
\hline 1.3 .2 .5 .2 & Maintainability & & & $\mathrm{X}$ & $\mathrm{X}$ & \\
\hline 1.3.2.5.3 & Availability & & $\mathrm{X}$ & $\mathrm{X}$ & $\mathrm{X}$ & \\
\hline 1.3 .2 .5 .4 & Operability and Maintainability & & $\mathrm{X}$ & & $\mathrm{X}$ & \\
\hline 1.3 .2 .6 & Environmental Conditions & & & & & $\mathrm{X}$ \\
\hline 1.3 .2 .7 & Transportability (Reserved) & $\mathrm{X}$ & & & & \\
\hline
\end{tabular}


Table 1-2. Verification Matrix. (5 sheets)

\begin{tabular}{|c|c|c|c|c|c|c|}
\hline $\begin{array}{l}\text { Section it } 3 \text {. } \\
\text { Taragraph. }\end{array}$ & (1.3. & Wia & I. & 18 & 13 & 3 \\
\hline 1.3 .2 .8 & Flexibility and Expansion & & & & $X$ & $\mathrm{X}$ \\
\hline 1.3 .2 .9 & Portability (Reserved) & $\mathrm{x}$ & & & & \\
\hline 1.3 .3 & Design and Construction & & & & & $\mathrm{X}$ \\
\hline 1.3.3.1 & Materials & $\mathrm{X}$ & & & & \\
\hline 1.3 .3 .1 .1 & Containment System Design & & & $\mathrm{x}$ & & $\mathrm{X}$ \\
\hline 1.3.3.1.2 & Design Load For Facilities & & $\mathrm{X}$ & & & \\
\hline 1.3.3.1.3 & Monitoring and Control Systems & & & & $\mathrm{X}$ & \\
\hline 1.3 .3 .1 .4 & Ventilation and Filtration Systems & & & & $\mathrm{X}$ & \\
\hline 1.3.3.1.5 & Groundwater Monitoring System & & & & $\mathrm{X}$ & \\
\hline 1.3.3.6.1 & Surface Water Monitoring System & & & & $\mathrm{X}$ & \\
\hline 1.3.3.7.1 & Remediation of Leaks & & & & $\mathrm{X}$ & \\
\hline 1.3.3.8.1 & Corrosion Prevention and Control & & & & $\mathrm{X}$ & $\mathrm{X}$ \\
\hline 1.3.3.9.1 & Shielding Criteria & & $\mathrm{X}$ & & & \\
\hline 1.3.3.2 & Radiation & $\mathrm{X}$ & & & & \\
\hline 1.3 .3 .2 .1 & $\begin{array}{l}\text { DOE Sponsored Radiological } \\
\text { Requirements } \\
\end{array}$ & & $\mathrm{X}$ & & & \\
\hline 1.3.3.2.1.1 & Maximum Contaminant Levels & & & & $\mathrm{X}$ & \\
\hline 1.3.3.2.2 & $\begin{array}{l}\text { Non-DOE Sponsored Radiological } \\
\text { Requirements }\end{array}$ & & $\mathrm{X}$ & & & \\
\hline 1.3.3.2.3 & Accidental Public Exposure & & $\mathrm{X}$ & $\mathrm{x}$ & & \\
\hline 1.3.3.3 & Name Plates and Product Markings & & $\mathrm{X}$ & & & \\
\hline 1.3 .3 .4 & Workmanship (Reserved) & $\mathrm{X}$ & & & - & \\
\hline 1.3.3.5 & Interchangeability (Reserved) & $\mathrm{X}$ & & & & \\
\hline 1.3 .3 .6 & Safety & $\mathrm{X}$ & & & & \\
\hline 1.3 .3 .6 .1 & Safety Analysis & & $\mathrm{X}$ & & & \\
\hline 1.3 .3 .6 .2 & Unreviewed Safety Questions & & $\mathrm{X}$ & & & \\
\hline 1.3 .3 .6 .3 & Technical Safety Requirements & & $\mathrm{X}$ & & & \\
\hline 1.3.3.6.4 & Environmental, Safety and Health & & $\mathrm{X}$ & & $\mathrm{X}$ & \\
\hline 1.3.3.6.4.1 & Environmental Surveillance & & & & $\mathrm{X}$ & \\
\hline 1.3.3.6.5 & Fire Protection & & $\mathrm{X}$ & & & \\
\hline 1.3.3.6.6 & ALARA & & $\mathrm{X}$ & & & \\
\hline
\end{tabular}


Table 1-2. Verification Matrix. (5 sheets)

\begin{tabular}{|c|c|c|c|c|c|c|}
\hline $\begin{array}{l}\text { Section } 13 \\
\text { Paragraph }\end{array}$ & (1.:- & Nia: & 1 & 10 & 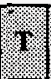 & III \\
\hline 1.3.3.6.7 & Design for Safety & & $\mathrm{X}$ & & & $\mathrm{X}$ \\
\hline 1.3 .3 .6 .8 & Worker Occupational Safety & & $\mathrm{X}$ & & & \\
\hline 1.3.3.6.9 & Maintenance Management Program & & $\mathrm{X}$ & & & \\
\hline 1.3 .3 .7 & Human Engineering & & & $\mathrm{X}$ & & $\mathrm{X}$ \\
\hline 1.3 .3 .8 & Nuclear Control & $\mathrm{X}$ & & & & \\
\hline 1.3.3.8.1 & Criticality & & $\mathrm{X}$ & & & \\
\hline 1.3 .3 .8 .2 & $\begin{array}{l}\text { Safety/Hazard Classification for Nuclear } \\
\text { facilities and Operations }\end{array}$ & & & $\bar{x}$ & & $\mathrm{x}$ \\
\hline 1.3 .3 .9 & System Security & & $\mathrm{X}$ & $\mathrm{X}$ & & \\
\hline 1.3 .3 .10 & $\begin{array}{l}\text { Government Furnished Property Usage } \\
\text { (Reserved) }\end{array}$ & $\bar{X}$ & & & & \\
\hline 1.3 .3 .11 & $\begin{array}{l}\text { Computer Resource Reserve Capacity } \\
\text { (Reserved) }\end{array}$ & $\mathrm{X}$ & & & & \\
\hline 1.3 .4 & Documentation & & $\mathrm{X}$ & & & \\
\hline 1.3 .5 & Personnel and Training & $\mathrm{X}$ & & & & \\
\hline 1.3 .6 & Precedence & $\bar{X}$ & & & & \\
\hline 1.3 .7 & Qualification (Reserved) & $\mathrm{X}$ & & & & \\
\hline 1.3 .8 & Standard Sample (Reserved) & $\mathrm{X}$ & & & & \\
\hline 1.4 & Quality Assurance Provisions & & $X$ & & & \\
\hline 1.4 .1 & Responsibility For Inspections & & $\mathrm{X}$ & $\mathrm{x}$ & $\mathrm{X}$ & \\
\hline 1.4 .2 & Special Tests and Examinations & $\mathrm{X}$ & & & & \\
\hline 1.4 .3 & Requirements Cross Reference & $x$ & & & & \\
\hline 1.5 & $\begin{array}{l}\text { Preparation for Delivery (or Operations) } \\
\text { (Reserved) }\end{array}$ & $\mathrm{X}$ & & & & \\
\hline 1.6 & Notes & $\mathrm{X}$ & & & & \\
\hline 1.6 .1 & List of Terms & $\mathrm{X}$ & & & & \\
\hline
\end{tabular}


Table 1-2. Verification Matrix. (5 sheets)

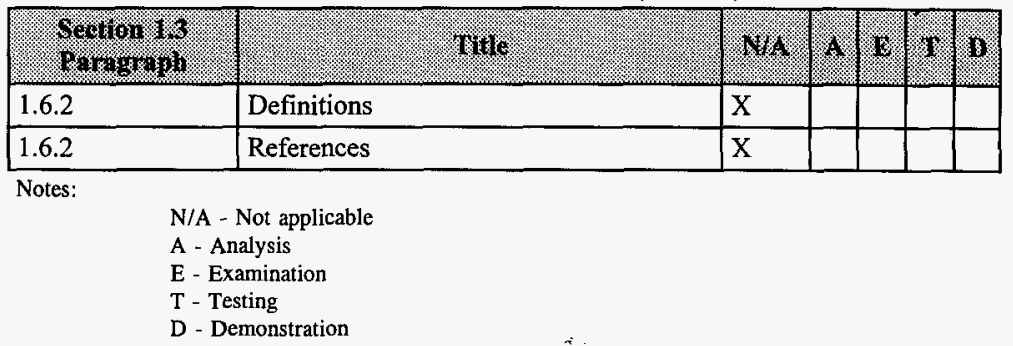

\subsubsection{Requirements Cross Reference}

See Table 1-3.

\subsection{PREPARATION FOR DELIVERY (or OPERATIONS)}

Reserved

Table 1-3. Requirements Traceability Matrix. (8 sheets)

\begin{tabular}{|c|c|c|}
\hline 60 & 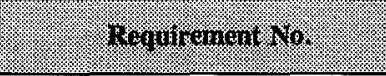 & 3). \\
\hline \multicolumn{3}{|c|}{ Performance Requirements } \\
\hline 1.3 .2 .3 .15 .1 & 40CFR264.1032 & Gaseous Emission Limits \\
\hline 1.3 .2 .3 .15 .1 & 40CFR264.1054 & $\begin{array}{l}\text { Pressure Relief Devices/ Control of } \\
\text { Emissions }\end{array}$ \\
\hline 1.3 .3 .6 .6 & WHC-SD-WM-FRD-020 & ALARA-Design \\
\hline 1.3 .3 .8 .1 & WHC-SD-WM-FRD-020 & Criticality \\
\hline 1.3 .3 .9 & DOE 470.1 & System Security \\
\hline 1.3.2.2.1.1 & DOE 4700.1 & Project Management System \\
\hline 1.3 .2 .4 .2 & DOE/RL 93-08 & Hanford Mission Plan \\
\hline 1.3 .3 .6 .9 & DOE4330.4B & Maintenance Management Program \\
\hline 1.3.3.6.4.1 & DOE.5400.5, Chapter IV, 5.b & Environmental surveillance \\
\hline 1.3.3.2.1.1 & DOE.5400.5, Chapter II, 1.d(3) & Maximum contaminant levels \\
\hline 1.3 .3 .1 .7 & DOE.5400.5, Chapter II, 3.c(2) & Remediation of leaks \\
\hline
\end{tabular}


Table 1-3. Requirements Traceability Matrix. (8 sheets)

\begin{tabular}{|c|c|c|}
\hline Soctor 1300 & Maguiroment ro. & iscsolition \\
\hline 1.3 .4 & DOE5480.19 & Conduct of Operations \\
\hline 1.3.3.6.2 & DOE5480.21.10.a & Unreviewed Safety Questions \\
\hline 1.3 .3 .6 .3 & DOE5480.22.9.a & Technical Safety Requirements \\
\hline 1.3.3.6.1 & DOE5480.23.8 & Perform Safety Analysis \\
\hline 1.3.3.8.1 & DOE 5480.24 .7 & Nuclear Criticality Safety \\
\hline 1.3.3.6.4 & DOE5480.4 & $\begin{array}{l}\text { Environmental Protection, Safety and } \\
\text { Health Protection }\end{array}$ \\
\hline 1.3.3.6.5 & DOE5480.7.A.8.i & Fire Protection \\
\hline 1.3.3.6.7 & $\begin{array}{l}\text { DOE.5820.2A, Chapter I, } \\
\text { 3.a(1)(a) }\end{array}$ & Design for safety \\
\hline 1.3 .3 & $\begin{array}{l}\text { DOE.5820.2A, Chapter I, } \\
\text { 3.a(1)(b) }\end{array}$ & Comply with Orders during Design \\
\hline 1.3.3.6.7 & DOE.5820.2A, Chapter I, 3.a(2) & Review of Existing Facilities \\
\hline 1.3 .2 .3 .6 .1 & $\begin{array}{l}\text { DOE.5820.2A, Chapter I, } \\
\text { 3.b(1)(a) }\end{array}$ & $\begin{array}{l}\text { Characterize Waste/Radiation } \\
\text { Protection }\end{array}$ \\
\hline 1.3 .4 & $\begin{array}{l}\text { DOE. } 5820.2 \mathrm{~A} \text {, Chapter I, } \\
3 . \mathrm{b}(1)(\mathrm{b})\end{array}$ & $\begin{array}{l}\text { Waste Characteristics Documented in } \\
\text { Safety Analysis Report }\end{array}$ \\
\hline 1.3 .3 .1 .1 & $\begin{array}{l}\text { DOE.5820.2A, Chapter I, } \\
3 . b(2)(a)\end{array}$ & $\begin{array}{l}\text { Handling, Transfer and Storage } \\
\text { Facilities will be Doubly Contained }\end{array}$ \\
\hline 1.3 .3 .1 .1 & $\begin{array}{l}\text { DOE.5820.2A, Chapter I, } \\
3 . b(2)(b)\end{array}$ & Radiation Limits for Single Pipes \\
\hline 1.3 .3 .1 .1 & $\begin{array}{l}\text { DOE.5820.2A, Chapter I, } \\
3 . b(2)(c)\end{array}$ & Secondary Containment Maintenance \\
\hline 1.3.3.1.1 & $\begin{array}{l}\text { DOE. } 5820.2 \mathrm{~A} \text {, Chapter I, } \\
3 . \mathrm{b}(2)(\mathrm{d})\end{array}$ & Containment/Recovery of Leaks \\
\hline 1.3 .3 .1 .4 & $\begin{array}{l}\text { DOE.5820.2A, Chapter I, } \\
3 . b(2)(f)\end{array}$ & Ventilation \\
\hline 1.3 .3 .1 .8 & $\begin{array}{l}\text { DOE. } 5820.2 \mathrm{~A} \text {, Chapter I, } \\
3 . \mathrm{b}(2)(\mathrm{g})\end{array}$ & Corrosion Prevention \\
\hline 1.3 .3 .1 .3 & $\begin{array}{l}\text { DOE.5820.2A, Chapter I, } \\
\text { 3.b(2)(h) }\end{array}$ & Control Instrument \\
\hline 1.3.3.8.1 & DOE.5820.2A, Chapter I, 3.b(2)(i) & Nuclear Criticality \\
\hline 1.3.2.5.2 & DOE.5820.2A, Chapter I, 3.b(2)(j) & Maintenance \\
\hline
\end{tabular}


Table 1-3. Requirements Traceability Matrix. (8 sheets)

\begin{tabular}{|c|c|c|}
\hline Socton 30 & Reguingnimin No & Bescription \\
\hline 1.3.3.1.3 & $\begin{array}{l}\text { DOE.5820.2A, Chapter I, } \\
\text { 3.b(2)(k) }\end{array}$ & Loss of Power \\
\hline 1.3.3.1.3 & $\begin{array}{l}\text { DOE.5820.2A, Chapter I, } \\
\text { 3.b(3)(a) } \\
\end{array}$ & Monitoring/Leak Detection Capabilities \\
\hline 1.3 .3 .1 .3 & $\begin{array}{l}\text { DOE.5820.2A, Chapter I, } \\
\text { 3.b(3)(b) }\end{array}$ & Leak Detection \\
\hline 1.3 .3 .1 .8 & $\begin{array}{l}\text { DOE.5820.2A, Chapter I, } \\
\text { 3.b(3)(c) }\end{array}$ & Inspection/Corrosion Detection \\
\hline 1.3.3.1.3 & $\begin{array}{l}\text { DOE. } 5820.2 \mathrm{~A}, \text { Chapter I, } \\
\text { 3.b(3)(d) }\end{array}$ & Back-up Power \\
\hline 1.3 .3 .1 .6 & $\begin{array}{l}\text { DOE.5820.2A, Chapter I, } \\
\text { 3.b(3)(e) }\end{array}$ & Surface Water Systems \\
\hline 1.3 .3 .1 .5 & \begin{tabular}{|l|} 
DOE.5820.2A, Chapter I, \\
3.b(3)(f) \\
\end{tabular} & Ground Water Monitoring \\
\hline 1.3.3.1.7 & $\begin{array}{l}\text { DOE.5820.2A, Chapter I, } \\
\text { 3.b(4)(a) } \\
\end{array}$ & Contingency after Leak \\
\hline 1.3.3.1.7 & \begin{tabular}{|l} 
DOE.5820.2A, Chapter I, \\
3.b(4)(b) \\
\end{tabular} & Remediation after Leak \\
\hline 1.3 .3 .1 .7 & $\begin{array}{l}\text { DOE.5820.2A, Chapter I, } \\
3 . \mathrm{b}(4)(\mathrm{c})\end{array}$ & Restart Operations after Leak \\
\hline 1.3 .2 .5 .2 & \begin{tabular}{|l|} 
DOE. $5820.2 \mathrm{~A}$, Chapter I, \\
3.b(4)(e) \\
\end{tabular} & Maintenance \\
\hline 1.3 .4 & $\begin{array}{l}\text { DOE. } 5820.2 \mathrm{~A} \text {, Chapter I, } \\
\text { 3.b(4)(f) }\end{array}$ & Emergency Procedures \\
\hline 1.3 .5 & DOE.5820.2A, Chapter I, 3.b(5) & Training \\
\hline 1.4 & DOE.5820.2A, Chapter I, 3.b(6) & $\begin{array}{l}\text { Operations Conducted in Accordance } \\
\text { with ANSI/ASME }\end{array}$ \\
\hline 1.3.2.3.18.1 & \begin{tabular}{|l|} 
DOE. $5820.2 \mathrm{~A}$, Chapter I, \\
3.b(7)(c)
\end{tabular} & Corrosion Control \\
\hline 1.3 .2 .3 .2 .1 & \begin{tabular}{|l|} 
DOE.5820.2A, Chapter I, \\
3.b(7)(d) \\
\end{tabular} & Treatment Reagents \\
\hline 1.3 .2 .1 .2 & \begin{tabular}{|l|} 
DOE. 5820.2A, Chapter I, \\
3.b(7)(e) \\
\end{tabular} & Waste Compatibility \\
\hline 1.3 .3 .6 .1 & $\begin{array}{l}\text { DOE. } 5820.2 \mathrm{~A}, \text { Chapter I, } \\
\text { 3.c(2)(b) }\end{array}$ & Safety Analysis \\
\hline
\end{tabular}


Table 1-3. Requirements Traceability Matrix. (8 sheets)

\begin{tabular}{|c|c|c|}
\hline Section 13.0 & 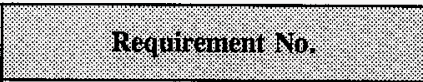 & 36014101 \\
\hline 1.3 .3 .1 .1 & $\begin{array}{l}\text { DOE. 5820.2A, Chapter I, } \\
3 . \mathrm{c}(2)(\mathrm{c})\end{array}$ & Waste Inventory Monitoring \\
\hline 1.3 .3 .1 .1 & $\begin{array}{l}\text { DOE.5820.2A, Chapter I, } \\
3 . c(2)(d)\end{array}$ & Rad Limits Single Pipes \\
\hline 1.3 .3 .1 .4 & $\begin{array}{l}\text { DOE.5820.2A, Chapter I, } \\
3 . c(2)(\mathrm{e})\end{array}$ & Ventilation \\
\hline 1.3 .3 .8 .1 & DOE.5820.2A, Chapter I, 3.c(2)(f) & Nuclear Criticality \\
\hline 1.3 .2 .5 .2 & $\begin{array}{l}\text { DOE.5820.2A, Chapter I, } \\
3 . \mathrm{c}(2)(\mathrm{g})\end{array}$ & Maintenance \\
\hline 1.3 .3 .1 .3 & $\begin{array}{l}\text { DOE. } 5820.2 \mathrm{~A}, \text { Chapter I, } \\
3 . \mathrm{c}(2)(\mathrm{h})\end{array}$ & Power Loss \\
\hline 1.3 .3 .1 .3 & $\begin{array}{l}\text { DOE.5820.2A, Chapter I, } \\
\text { 3.c(3)(a) }\end{array}$ & Monitoring and Surveillance \\
\hline 1.3 .3 .1 .8 & $\begin{array}{l}\text { DOE } 5820.2 A \text {, Chapter I, } \\
\text { 3.c(3)(b) }\end{array}$ & Inspection/Corrosion Detect \\
\hline 1.3 .3 .1 .3 & $\begin{array}{l}\text { DOE 5820.2A, Chapter I, } \\
\text { 3.c(3)(c) }\end{array}$ & Emergency Power \\
\hline 1.3.3.1.5 & $\begin{array}{l}\text { DOE } 5820.2 A \text {, Chapter I, } \\
3 . \mathrm{c}(3)(\mathrm{d})\end{array}$ & Groundwater Monitoring \\
\hline 1.3 .3 .1 .7 & DOE.5820.2A, Chapter I, 3.c(4) & Contingency Plan \\
\hline 1.3 .5 & DOE 5820.2A, Chapter I, 3.c(5) & Training \\
\hline 1.4 & DOE 5820.2A, Chapter I, 3.c(6) & QA \\
\hline 1.3 .2 .1 .2 & DOE.5820.2A, Chapter II, 3.a(1) & Waste Evaluation \\
\hline 1.3 .2 .3 .13 .1 & DOE.5820.2A, Chapter II, 3.a(2) & TRU Limits \\
\hline 1.3.2.3.13.1 & DOE.5820.2A, Chapter II, 3.a(3) & TRU Limits \\
\hline 1.3.2.1.1 & DOE.5820.2A, Chapter II, 3.b(1) & Waste Volume Reduction \\
\hline 1.3 .2 .3 .6 .1 & DOE.5820.2A, Chapter II, 3.b(2) & Assay/Analysis Requirements \\
\hline 1.3.2.3.13.1 & DOE.5820.2A, Chapter II, 3.d & TRU Containers \\
\hline 1.3 .2 .1 .1 & DOE.5820.2A, Chapter III, 3.c(1) & Waste Volume Reduction \\
\hline 1.3 .2 .1 .1 & DOE.5820.2A, Chapter III, 3.c(2) & Minimize LLW Generation \\
\hline 1.3 .2 .1 .2 & DOE.5820.2A, Chapter III, 3.c(3) & Waste Segregation \\
\hline 1.3 .2 .1 .1 & DOE.5820.2A, Chapter III, 3.c(4) & Design to Minimize LLW Generation \\
\hline 1.3 .2 .3 .13 .1 & DOE.5820.2A, Chapter III, 3.d & LLW Characterization \\
\hline
\end{tabular}


Table 1-3. Requirements Traceability Matrix. (8 sheets)

\begin{tabular}{|c|c|c|}
\hline Scchon 1.30 . & 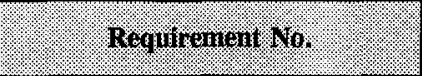 & 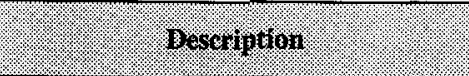 \\
\hline 1.3 .2 .3 .18 .1 & DOE.5820.2A, Chapter III, 3.e(1) & Transport of Waste \\
\hline 1.3 .2 .3 .18 .2 & DOE.5820.2A, Chapter III, 3.e(2) & $\begin{array}{l}\text { Determine LLW Waste Acceptance } \\
\text { Criteria }\end{array}$ \\
\hline 1.3 .2 .3 .18 .2 & DOE.5820.2A, Chapter III, 3.e(3) & Waste Certification \\
\hline 1.3 .2 .3 .16 .1 & DOE.5820.2A, Chapter III, 3.e(4) & Audit of Certification Programs \\
\hline 1.3 .2 .3 .18 .2 & DOE.5820.2A, Chapter III, 3.e(5) & $\begin{array}{l}\text { Waste Acceptance Criteria for Storage, } \\
\text { Treatment, or Disposal Facilities }\end{array}$ \\
\hline 1.3 .2 .3 .13 .1 & DOE.5820.2A, Chapter III, 3.g(1) & Transport of Waste \\
\hline 1.3 .2 .2 .2 .2 & DOE.5820.2A, Chapter III, 3.g(2) & Annual Disposal Forecast \\
\hline 1.3 .2 .3 .18 .2 & DOE.5820.2A, Chapter III, 3.g(3) & Generator Waste Certification \\
\hline 1.3 .3 .3 & DOE.5820.2A, Chapter III, 3.g(4) & Labelling \\
\hline 1.3 .4 & DOE.5820.2A, Chapter III, 3.m(1) & Waste Data Records \\
\hline 1.3 .4 & DOE.5820.2A, Chapter III, 3.m(2) & Waste Manifest \\
\hline 1.3 .3 .6 .4 .1 & DOE.5820.2A, Chapter III, 3.k & Environmental surveillance \\
\hline 1.3 .2 .3 .10 .1 & DOE.5820.2A, Chapter V, 3.a & Program Development \\
\hline 1.3 .4 & DOE.5820.2A, Chapter V, 3.a(2) & $\begin{array}{l}\text { Operation Records for } \\
\text { Decommissioning }\end{array}$ \\
\hline 1.3.2.3.10.1 & DOE.5820.2A, Chapter V, 3.a(5) & Transfer of Responsibility for Facilities \\
\hline 1.3 .2 .3 .10 .1 & DOE.5820.2A, Chapter V, 3.b & Design for Decommissioning \\
\hline 1.3.2.3.10.1 & DOE.5820.2A, Chapter V, 3.c & Post Operational Activities \\
\hline 1.3 .2 .3 .6 .1 & DOE/RL 94-001 & $\begin{array}{l}\text { Characterization Information } \\
\text { Accessibility }\end{array}$ \\
\hline 1.3 .2 .3 .9 .1 & WHC-SD-WM-DQO-008 & $\begin{array}{l}\text { Tank Waste Characterization } \\
\text { Requirements }\end{array}$ \\
\hline 1.3 .3 .1 .2 & WHC-SD-WM-FRD-020 & Design Loads for Facilities \\
\hline 1.3 .4 & WHC-SD-WM-FRD-020 & Documentation \\
\hline 1.3 .2 .6 & WHC-SD-WM-FRD-020 & Environmental Conditions \\
\hline 1.3 .2 .8 & WHC-SD-WM-FRD-020 & Flexibility and Expansion \\
\hline 1.3.2.2.2.1 & 95-PRI-073 & Estimated TWRS Project Schedule \\
\hline 1.3 .3 .8 .2 & WHC-SD-WM-FRD-020 & Hazardous Waste Management \\
\hline 1.3 .3 .7 & WHC-SD-WM-FRD-020 & Human Factors \\
\hline 1.3 .2 .4 .2 & WHC-SD-WM-FRD-020 & Land Use \\
\hline
\end{tabular}


Table 1-3. Requirements Traceability Matrix. (8 sheets)

\begin{tabular}{|c|c|c|}
\hline setiron 1.300 & Hequinenientivo. & 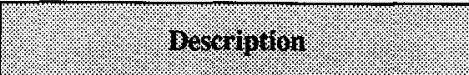 \\
\hline 1.3.3.2.2 & WHC-SD-WM-FRD-020 & $\begin{array}{l}\text { Non-DOE Sponsored Radiological } \\
\text { Requirements }\end{array}$ \\
\hline 1.3.2.3.15.1 & WHC-SD-WM-FRD-020 & Nonradionuclide Airborne Emissions \\
\hline 1.3.3.3.1.1 & WAC 246-247-090 & $\begin{array}{l}\text { Notification of Startup, Shutdown, or } \\
\text { other change that may affect Emissions } \\
\text { Measurement }\end{array}$ \\
\hline 1.3.2.3.6.1 & OSD-T-151-00017 & $\begin{array}{l}\text { Operating Specifications for } \\
\text { Aging-Waste Operations in } 241-\mathrm{AY} \text {, } \\
\text { and } 241-\mathrm{AZ}, \mathrm{P} .15 \text {, Section } 17.3 .1\end{array}$ \\
\hline 1.3 .2 .2 .1 .2 & OSD-T-151-00030 & $\begin{array}{l}\text { Operating Specification for Watch List } \\
\text { Tanks, P. 9, Section 30.2.A.3 (B) }\end{array}$ \\
\hline 1.3.2.2.1.2 & OSD-T-151-00030 & $\begin{array}{l}\text { Operating Specification for Watch List } \\
\text { Tanks, P. 9, Section 30.2.A.3, (A) }\end{array}$ \\
\hline 1.3 .2 .3 .18 .1 & WHC-SD-WM-FRD-020 & Base Feed \\
\hline 1.3 .2 .3 .18 .1 & WHC-SD-WM-FRD-020 & Complexant Waste Segregation \\
\hline 1.3 .2 .3 .18 .1 & WHC-SD-WM-FRD-020 & Criticality Prevention Requirement \\
\hline 1.3 .2 .3 .18 .1 & WHC-SD-WM-FRD-020 & Energetics \\
\hline 1.3 .2 .3 .18 .1 & WHC-SD-WM-FRD-020 & Heat Generation Limits \\
\hline 1.3 .2 .3 .18 .1 & WHC-SD-WM-FRD-020 & High Phosphate Waste \\
\hline 1.3 .2 .3 .18 .1 & WHC-SD-WM-FRD-020 & TRU Waste Segregation \\
\hline 1.3 .2 .3 .18 .1 & WHC-SD-WM-FRD-020 & $\begin{array}{l}\text { Transfer System Specific Gravity } \\
\text { Limits }\end{array}$ \\
\hline 1.3 .2 .3 .18 .1 & WHC-SD-WM-FRD-020 & Waste Pumpability \\
\hline 1.3 .2 .3 .18 .1 & WHC-SD-WM-FRD-020 & Solution Temperature Ranges \\
\hline 1.3 .2 .3 .18 .1 & WHC-SD-WM-FRD-020 & Transfer System Flush \\
\hline 1.3 .2 .3 .18 .1 & WHC-SD-WM-FRD-020 & Waste Characterization Data \\
\hline 1.3 .2 .3 .18 .1 & WHC-SD-WM-FRD-020 & Quantity of Retrieved Tank Waste \\
\hline 1.3 .2 .3 .17 .1 & WHC-SD-WM-FRD-020 & $\begin{array}{l}\text { Effluent Treatment Facility Influent } \\
\text { Restrictions }\end{array}$ \\
\hline 1.3 .2 .3 .17 .1 & WHC-SD-WM-FRD-020 & Untreated liquid effluents \\
\hline 1.3 .2 .3 .13 .1 & DOE 460.1 & $\begin{array}{l}\text { Onsite Shipment of Radioactive } \\
\text { Materials }\end{array}$ \\
\hline 1.3 .5 & WHC-SD-WM-FRD-020 & Personnel and Training \\
\hline
\end{tabular}


Table 1-3. Requirements Traceability Matrix. (8 sheets)

\begin{tabular}{|c|c|c|}
\hline 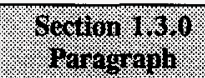 & 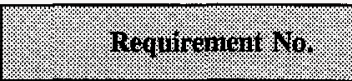 & Wostifiton \\
\hline 1.4 & WHC-SD-WM-FRD-020 & Quality Assurance Plan \\
\hline 1.3.3.2.3 & SEN-35-91 & Public Accidental Exposure \\
\hline 1.3.2.5 & DOE 6430.1A & Safety Class \\
\hline 1.3.3.1.9 & WHC-SD-GN-DGS-30011 & Shielding Criteria \\
\hline 1.3 .2 .4 .1 & DOE/EIS-0189 & Site Boundary \\
\hline 1.3 .2 .3 .13 .1 & WHC-SD-WM-FRD-020 & Solid Radioactive Waste Transfer \\
\hline 1.3 .2 .3 .18 .1 & WHC-SD-WM-OCD-015 & Chemical Compatibility \\
\hline 1.3.2.3.3.1 & WHC-SD-MAR-008 & HLW Constituents Limitations \\
\hline 1.3.2.3.15.1 & WHC-CM-7-5,2.5.2 & Radionuclide Emission limits \\
\hline 1.3.2.5.4 & WHC-SD-WM-ES-295 & Operability and maintainability \\
\hline 1.3.2.3.3.1 & E/B-SD-W236-RPT-022 & $\begin{array}{l}\text { Recycle of Water for tank waste } \\
\text { retrieval and pretreatment }\end{array}$ \\
\hline 1.3.2.3.12 & WAC173-303-630(1) & Dangerous waste container storage \\
\hline 1.4 .1 & WAC $173-303-630(6)$ & Container inspection \\
\hline 1.3 .2 .3 .12 .1 & WAC173-303-630(7) & Container storage area \\
\hline 1.3.3.6.5 & WAC173-303-630(8) & Container storage fire codes \\
\hline 1.3 .3 .1 .8 & WAC173-303-640(3) (a) (iii) & New tank system requirements \\
\hline 1.3 .4 & WAC173-303-640(3) (c) & New tank system requirements \\
\hline 1.3.3.1.1 & WAC173-303-640(3) (d) & New tank system requirements \\
\hline 1.3 .2 .3 .8 .1 & WAC173-303-640(3) (f) & New ancillary equipment \\
\hline 1.3.3.1.8 & WAC173-303-640(3) (g) & Corrosion protection for tanks \\
\hline 1.3.3.1.1 & WAC173-303-640(4) (b) & Tank secondary containment \\
\hline 1.3.3.1.1 & WAC173-303-640(4) (c) & Tank secondary containment \\
\hline 1.3.3.1.1 & WAC173-303-640(4) (d) & Tank secondary containment \\
\hline 1.3.3.1.1 & WAC173-303-640(4) (e) & Tank secondary containment \\
\hline 1.3.2.3.8.1 & WAC173-303-640(4) (f) & $\begin{array}{l}\text { Ancillary equipment secondary } \\
\text { containment }\end{array}$ \\
\hline 1.3.3.1.1 & WAC173-303-640(4) (g) & Dangerous waste containment \\
\hline 1.3.2.3.8.1 & WAC173-303-640(4) (i) (c) & Leak test for ancillary equipment \\
\hline 1.3.3.8.2 & WAC173-303-640(5) & Control of wastes entering tank \\
\hline 1.3.3.1.7 & WAC173-303-640(7) (a-c) & Response following leak or spill \\
\hline 1.3.3.6.4.1 & WAC173-303-640(7) (d) & Environmental surveillance \\
\hline
\end{tabular}


Table 1-3. Requirements Traceability Matrix. (8 sheets)

\begin{tabular}{|c|c|c|}
\hline 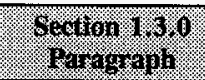 & 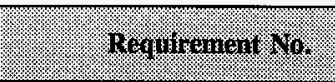 & 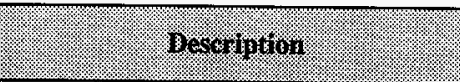 \\
\hline 1.3.3.1.5 & WAC $173-303-640(8)(a-c)$ & Ground water monitoring \\
\hline 1.3.3.1.5 & WAC173-303-640(9) (a-c) & Ground water monitoring \\
\hline 1.3 .2 .3 .15 .1 & WAC173-400 & General Regulations for air pollution \\
\hline 1.3 .2 .3 .15 .1 & WAC173-460 & Toxic air emissions and pollutants \\
\hline 1.3 .2 .3 .15 .1 & WAC173-480-060 & Emission standards \\
\hline 1.3 .2 .3 .15 .1 & WAC173-480-070 & Emission monitoring \\
\hline 1.3.3.6.6 & WAC246-220-7 & ALARA \\
\hline 1.3 .2 .3 .15 .1 & WAC246-247 & Radioactive air emission control \\
\hline 1.3 .3 .6 .8 & WHC-SD-WM-FRD-020 & Worker Occupational Safety \\
\hline 1.3.3.2.1 & WHC-SD-WM-FRD-020 & $\begin{array}{l}\text { Worker Radiological Safety: Hanford } \\
\text { Site Radiological Control Manual, } \\
\text { Chapter 1, Part 1, Section } 111 \text { and } \\
\text { Section } 112\end{array}$ \\
\hline \multicolumn{3}{|l|}{ Input/Output } \\
\hline 1.3 .2 .3 .1 & Input & Tank waste retrieval \\
\hline 1.3 .2 .3 .2 & Input & $\begin{array}{l}\text { Raw Materials for Retrieve Tank } \\
\text { Waste }\end{array}$ \\
\hline 1.3 .2 .3 .3 & Input & Recycled Water for Retrieval \\
\hline 1.3.2.3.4 & Input & $\begin{array}{l}\text { Sanitary Waste Services for Retrieve } \\
\text { Tank Waste }\end{array}$ \\
\hline 1.3 .2 .3 .5 & Input & Tank Operations Information \\
\hline 1.3.2.3.6 & Input & $\begin{array}{l}\text { Tank Waste Characterization } \\
\text { Information }\end{array}$ \\
\hline 1.3.2.3.7 & Input & Tank farm geological data \\
\hline 1.3 .2 .3 .8 & Output & $\begin{array}{l}\text { Retrieve Tank Waste Ancillary } \\
\text { Equipment and Systems }\end{array}$ \\
\hline 1.3 .2 .3 .9 & Output & $\begin{array}{l}\text { Retrieve Tank Waste Characterization } \\
\text { Requirements }\end{array}$ \\
\hline 1.3 .2 .3 .10 & Output & $\begin{array}{l}\text { Retrieve Tank Waste Excess } \\
\text { Facilities }\end{array}$ \\
\hline 1.3 .2 .3 .11 & Output & Retrieve Tank Waste Garbage \\
\hline 1.3 .2 .3 .12 & Output & Retrieve Tank Waste Hazardous Waste \\
\hline
\end{tabular}


Table 1-3. Requirements Traceability Matrix. (8 sheets)

\begin{tabular}{|c|c|c|}
\hline 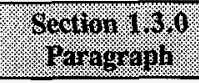 & 10 Reguiremantitio. & : \\
\hline 1.3 .2 .3 .13 & Output & $\begin{array}{l}\text { Retrieve Tank Waste Prepared Solid } \\
\text { Waste }\end{array}$ \\
\hline 1.3 .2 .3 .14 & Output & $\begin{array}{l}\text { Retrieve Tank Waste Transferrable } \\
\text { Resources }\end{array}$ \\
\hline 1.3.2.3.15 & Output & $\begin{array}{l}\text { Retrieve Tank Waste Treated Gaseous } \\
\text { Effluents }\end{array}$ \\
\hline 1.3 .2 .3 .16 & Output & $\begin{array}{l}\text { Retrieve Tank Waste Treated Liquid } \\
\text { Effluents }\end{array}$ \\
\hline 1.3 .2 .3 .17 & Output & $\begin{array}{l}\text { Retrieve Tank Waste Untreated Liquid } \\
\text { Effluents }\end{array}$ \\
\hline 1.3 .2 .3 .18 & Output & Retrieved Tank Waste \\
\hline
\end{tabular}


WHC-SD-WM-TRD-004, Rev. 0

This page intentionally left blank.

$1-68$ 


\subsection{TECHNICAL REQUIREMENTS SPECIFICATION FOR SINGLE-SHELL TANK RETRIEVAL - FUNCTION 4.2.2.1}

\section{$2.1 \quad$ SCOPE}

This chapter provides the technical requirements specification for the retrieval of waste from the single-shell underground storage tanks at the Hanford site. All activities covered by this scope are conducted in support of the Tank Waste Remediation System (TWRS) mission.

\subsubsection{Identification}

Program: Tank Waste Remediation System

Project: Single-Shell Tank (SST) Waste Retrieval System

\subsubsection{Single-Shell Tank Waste Retrieval System Overview}

The SST waste retrieval system is a major architecture element of the Tank Waste Remediation System (TWRS) and will mobilize sludge and solids contained within the Hanford site SSTs. The vast majority of the waste has a source based definition of high-level waste (HLW).

After mobilization, the tank waste sludges and solids are transported to Double-Shell Tanks (DSTs) for interim storage prior to treatment in the waste processing system. The SST waste retrieval system also provides the means to transfer waste from the waste storage system. To the extent practical, the SST waste retrieval system shall use existing components of the waste transfer system (e.g., underground piping, diversion boxes, and valve pits) to transfer mobilized tank waste to the designated DSTs.

Demonstration of tank waste mobilization technology is necessary to verify selected waste retrieval architectures can achieve established system performance requirements, thereby reducing program uncertainties and risks.

\subsubsection{Chapter Overview}

This preliminary system specification has been prepared using the format guidelines of military standard (MIL-STD) 490; system/segment specification. All Sections specified in MIL-STD-490 have been included in this chapter. In keeping with the conventions of MIL-STD-490, if a Section is not applicable for this specification, the Section title is provided followed by a statement identifying the Section as not applicable. 


\subsection{APPLICABLE DOCUMENTS}

System specification requirements, identified in Sections 2.3 and 2.4 , for accomplishing the SST waste retrieval system mission have been developed from many source documents. A requirements traceability matrix is provided in Table 2-2 identifying the source for each SST retrieval system specification requirement. These sources come from both government and non-government documents. A definition of government and non-government sources is given in Chapter 1.

\section{$2.3 \quad$ SYSTEM REQUIREMENTS}

\subsubsection{System Definitions}

The Tank Waste Remediation System Function and Requirements established function 4.2.2.1 Retrieve SST Waste. This function is defined as: The removal of wastes (i.e., saltcake, sludges, in-tank hardware, and discrete sources) from single-shell tanks (SSTs) and the transfer of these wastes to the Store In-Process Waste function. Wastes will be removed to the extent required for turnover of the tanks to closure. The function Retrieve Tank Waste has been decomposed into the following sub-functions. Figure 2-1 represents the function breakdown structure for retrieve SST waste.

\subsection{Detect SST Waste Leakage During Retrieval. Detect} and confirm leakage of waste from SSTs and ancillary components during sluicing to remove limited SST waste.

Detect leakage in the near-field zone by acquiring and evaluating the following data:

- Potential leakage conditions within the SST structure

- Waste inventory in the retrieval system

- Detect changes in the size and location of new and existing contaminant plumes.

Leakage detection during SST retrieval will be conducted as required to support the other functions and associated regulatory requirements until all of the SSTs have been retrieved. 
Figure 2-1. SST Waste Retrieval Functional Breakdown Structure.

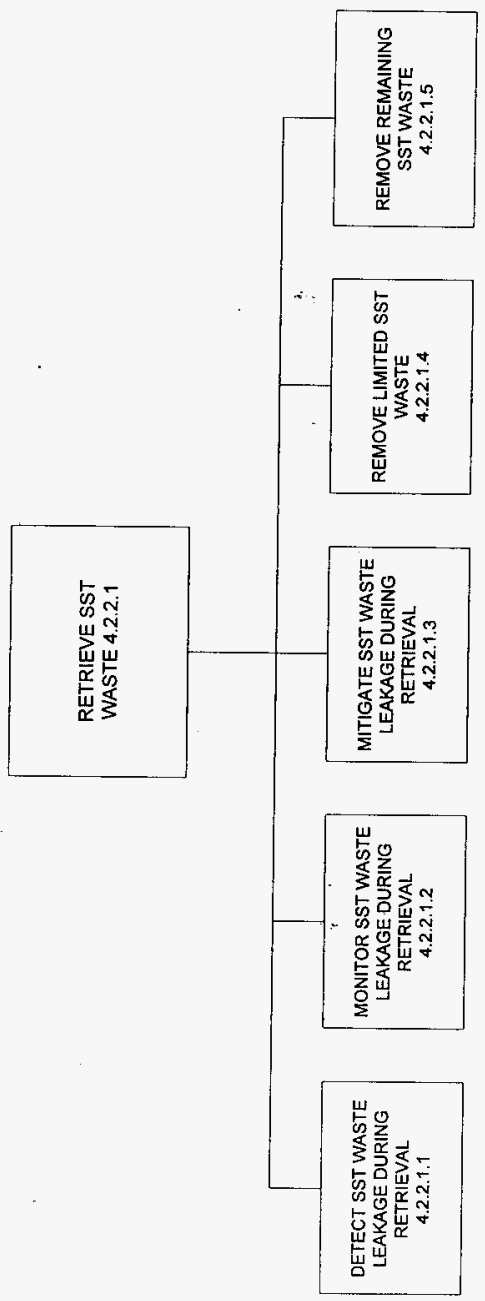


4.2.2.1.2 Monitor SST Waste Leakage During Retrieval. The waste leakage from retrieval of limited SST waste is monitored to obtain data that will be used to determine waste plume volume and plume direction. Monitoring includes obtaining, transmitting, receiving, recording, and displaying the leakage data.

\subsection{Mitigate SST Waste Leakage During Retrieval.} Operational, procedural, and administrative methods in conjunction with retrieval equipment design employed to mitigate leakage of SST waste during the removal of limited SST waste. Applicable to preventing new leaks from occurring and responding to new leaks if they do occur.

4.2.2.1.4 Remove Limited SST Waste. The removal of wastes from the SSTs using established technologies and the transfer of these wastes to the Store In-Process Waste function.

4.2.2.1.5 Remove Remaining SST Waste. The removal of SST waste, not removed by the Remove Limited SST Waste function, using established, enhanced, and/or alternate technologies and the transfer of these wastes to the Store In-Process Waste function. Wastes will be removed to the extent required for turnover of the tanks to closure.

\subsubsection{Interface Description}

Figure 2-2 represents the N-Square diagram for SST waste retrieval system interfaces.

\subsubsection{Risk Assumptions}

Table 2-1 lists the major program risk assumptions applicable to the SST Waste Retrieval system. 
Figure 2-2. [4.2.2.1] Retrieve SST Waste (N- Squared Diagram).
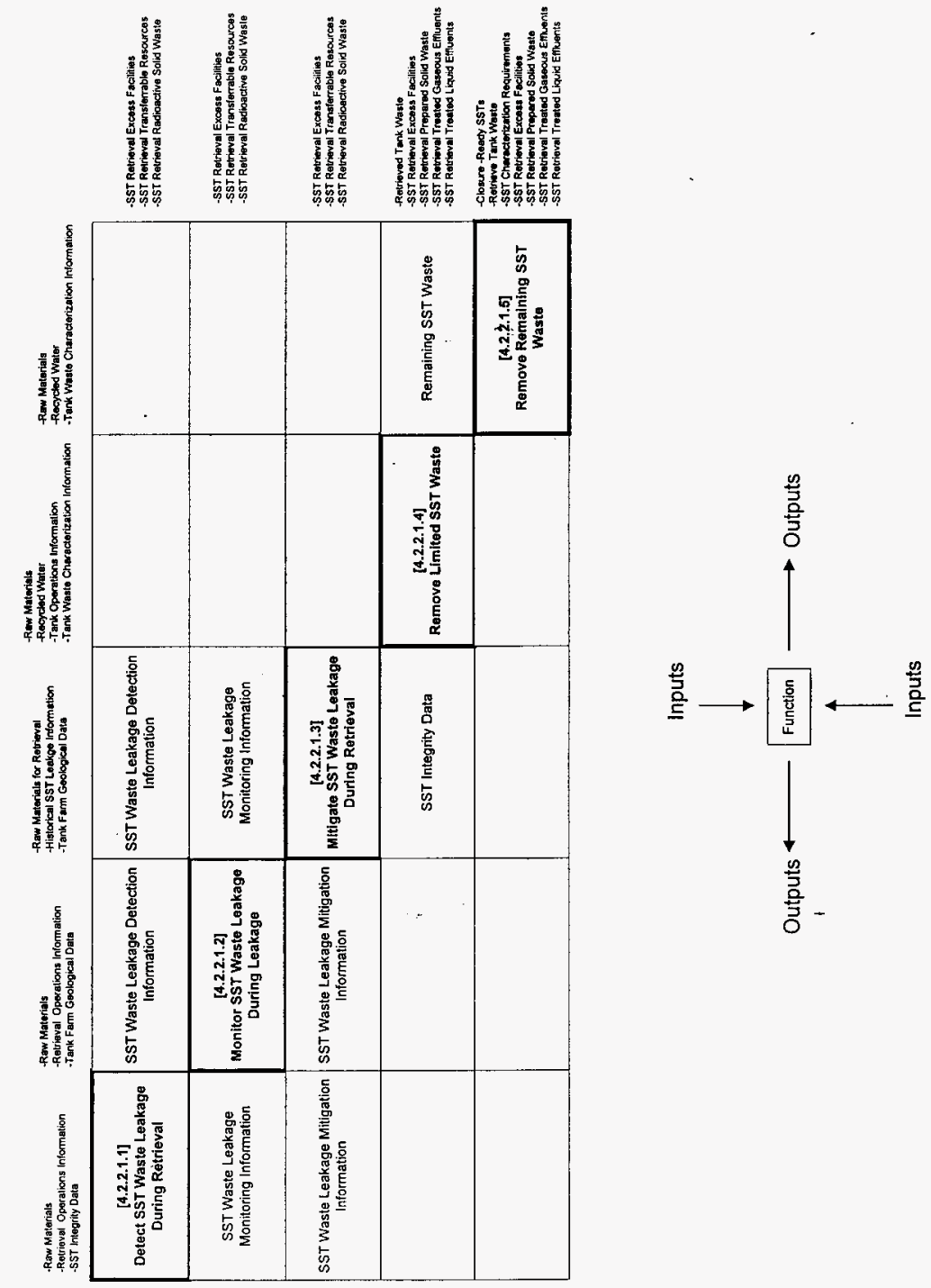
Table 2-1. Risk Assumptions.

\begin{tabular}{|c|c|c|}
\hline Rist Assumptions? & \multicolumn{2}{|c|}{ Potential Consequienco } \\
\hline $\begin{array}{l}\text { DST storage not adequate enough to meet } \\
\text { SST retrieval schedule. }\end{array}$ & 1. & $\begin{array}{l}\text { TPA (Ecology, et al., 1994) } \\
\text { milestones may not be met. } \\
\text { Legal and regulatory agency } \\
\text { implications. }\end{array}$ \\
\hline $\begin{array}{l}\text { Sufficient funds not available to retrieve waste } \\
\text { from SSTs/MUSTs by } 2018 \text {, close them by } \\
2024 \text {, or completely immobilize all DST } \\
\text { waste by } 2028 \text {. }\end{array}$ & 1. & $\begin{array}{l}\text { Unplanned delay in tank } \\
\text { retrieval. } \\
\text { Unplanned delay in tank } \\
\text { farm closure. }\end{array}$ \\
\hline $\begin{array}{l}\text { Waste retrieval (sluicing), processing and } \\
\text { storage functional processes cannot be } \\
\text { maintained in balance. }\end{array}$ & 1. & $\begin{array}{l}\text { One or more function } \\
\text { schedules may have to be } \\
\text { slipped or their processes } \\
\text { will have to be modified. } \\
\text { Current cost projections } \\
\text { exceeded. }\end{array}$ \\
\hline $\begin{array}{l}\text { Leakages which exceed specified limits may } \\
\text { delay SST retrieval and tank farm closure. }\end{array}$ & 1. & $\begin{array}{l}\text { Current cost projections } \\
\text { exceeded. } \\
\text { Workers exposed to } \\
\text { unacceptable risk. }\end{array}$ \\
\hline $\begin{array}{l}\text { Health and safety issues may not be resolved } \\
\text { in a timely manner to meet regulatory and } \\
\text { project schedule requirements. }\end{array}$ & 1. & Work stoppage or delay. \\
\hline $\begin{array}{l}\text { Cannot remove or is not practical to remove } \\
\text { enough waste to reduce the level of residual } \\
\text { radionuclide and hazardous chemicals below } \\
\text { established thresholds. }\end{array}$ & 1. & $\begin{array}{l}\text { Additional effort required to } \\
\text { remove substances left in } \\
\text { SSTs and MUSTs although } \\
\text { all waste practical was } \\
\text { removed. } \\
\text { Fines for not complying with } \\
\text { TPA (Ecology, et al., 1994) } \\
\text { agreements. }\end{array}$ \\
\hline $\begin{array}{l}\text { Planned approach to close the SST farm as a } \\
\text { landfill is changed to a clean close } \\
\text { requirement. For example: } \\
\text { Changed to clean close after } 99 \% \text { waste } \\
\text { removed, or, } \\
\text { Changed to clean close when } 99 \% \text { waste } \\
\text { cannot be removed. }\end{array}$ & 1. & $\begin{array}{l}\text { Effort wasted on wrong } \\
\text { clean-up goal. } \\
\text { Tanks must be removed and } \\
\text { the soil cleaned. }\end{array}$ \\
\hline
\end{tabular}




\subsubsection{Characteristics}

Performance and physical characteristics contained in this Section are from requirements identified in the TWRS Function and Requirements document (WHC 1996). Performance requirements identified in the TWRS Functions and Requirements document were reviewed and associated with the appropriate characteristics Section of this specification. Constraints identified in the TWRS Functions and Requirements document were reviewed and transformed into system specification requirements. The complete text of performance requirements and constraints are contained in the TWRS Functions and Requirements document. Table 2-2 includes allocation of regulatory constraints and performance requirements to appropriate system and segment elements.

\subsubsection{Performance Characteristics}

This paragraph is divided into subparagraphs which describe the SST Waste Retrieval System capabilities in the context of the requirements that define the SST Retrieval System function.

\subsection{Allowable Heel Following Retrieval From SSTs}

The waste retrieval system shall reduce the waste inventory to a maximum heel of $360 \mathrm{cu}$. ft. in 100 series and $30 \mathrm{cu}$. ft. in 200 series SSTs or limit of waste retrieval technology, whichever is less.

Source: TPA M-45-00

\subsection{SST Waste Retrieval Rate}

The SST waste retrieval rate must average approximately 21 cubic meters per day of SST waste averaged over the 14 years 9 months allowed for retrieval by the TPA milestones. This waste retrieval rate is a linear assumption, will vary over time, and does not include solutions (if any) added to mobilize the SST wastes.

Source: This requirement is derived from the Hanford Federal Facility Agreement and Consent Order milestones M-45-05 (states that SST waste retrieval shall be completed by $9 / 30 / 2018$ ) and the inventory of waste contained in the SSTs.

SST waste retrieval shall be initiaated in line with the following schedule (Note: 241-C-106 is the demonstration tank and is not included in this list): 


$\begin{array}{lc}\text { Year } & \text { Number of Tanks } \\ 2003 & 1 \\ 2004 & 2 \\ 2005 & 3 \\ 2006 & 4 \\ 2007 & 5 \\ 2008 & 5 \\ 2009 & 7 \\ 2010 & 8 \\ 2011 & 10 \\ 2012 & 12 \\ 2013 & 14 \\ 2014 & 17 \\ 2015 & 20 \\ 2016 & 20 \\ 2017 & 20 \\ \text { Total } & 148\end{array}$

Source: This requirement is derived from the Hanford Federal Facility Agreement and Consent Order milestones M-45-05.T01 to T15.

\subsection{Complete closure of SSTs}

Closure will follow retrieval of as much tank waste as technically possible, with tank waste residues not to exceed 360 cubic feet $\left(\mathrm{ft}^{3}\right)$ in each of the 100 series tanks, $30 \mathrm{ft}^{3}$ in each of the 200 series tanks, or the limit of waste retrieval technology capability, whichever is less. If the DOE believes that waste retrieval to these levels is not possible for a tank, then DOE will submit a detailed explanation to EPA and Ecology explaining why these levels cannot be achieved, and specifying the quantities of waste that the DOE proposes to leave in the tank. The request will be approved or disapproved by EPA and Ecology on a tank-by-tank basis.

Following completion of retrieval, six operable units (tank farms)(200-BP-7, 200-PO-3, 200-RO-4, 200-TP-5, 200-TP-6, 200-UP-3), will be remediated in accordance with the approved closure plans. Final closure of the operable units (tanks farms) shall be defined as regulatory approval of completion of closure actions and commencement of post-closure actions.

For the purposes of this agreement all units located within the boundary of each tank farm will be closed in accordance with WAC 173-303-610. This includes contaminated soil and ancillary equipment that were previously designated as RCRA past practice units.

Any equipment modified or replaced will meet interim status standards. In evaluating closure options for SSTs, contaminated soil, and ancillary equipment, Ecology and EPA will consider cost, technical practicability, and potential exposure to radiation. Closure of all 
units within the boundary of a given tank farm will be addressed in a closure plan for the SSTs. Closure of all Single-Shell Tanks shall be completed by 9/30/2024.

Source: $\quad$ TPA M-45-00

November 2004 - Submit Tank Closure/Post-Closure Plan for Selected Closure Demonstration Operable Unit or Tank Farm to Ecology for Approval.

Source: TPA M-45-06-T01

September 2006 - Ecology Will Issue Final Closure/Post Closure Plan For Selected Closure Demonstration Operable Unit or Tank Farm.

Source: $\quad$ TPA M-45-06-T02

March 2012 - Initiate Closure Actions on an Operable Unit or Tank Farm Basis. Closure Shall Follow Completion of The Retrieval Actions Under Proposed Milestone.

Source: TPA M-45-06-T03

March 2014 - Complete closure actions on one operable unit or tank farm.

Source: TPA M-45-06-T04

\subsection{Retrieval Method Selection}

The primary method for removal of wastes from SSTs has not been selected. However, demonstrations of hydraulic methods (i.e., sluicing) are planned for 241-C-106. Heel removal systems are under evaluation.

Issue: A variety of retrieval methods exist for removal of tank waste. Performance measures such as, environmental, public health and safety, regulatory compliance, technical feasibility, and life-cycle costs should be critical for retrieval technology selection.

Additionally, the retrieval method must be able to remove the waste to extent required for turnover of the tanks for closure.

Required Analysis: An Alternative Generation Analysis (AGA) on selected retrieval method is being conducted.

\subsection{Waste Minimization/Volume Reduction}

Waste minimization/volume reduction requirements are common to both SSTs and DSTs and are detailed in Chapter 1. 


\subsection{Waste Compatibility/Segregation}

Waste compatibility/segregation requirements are common to both SSTs and DSTs and are detailed in Chapter 1.

\subsection{Leakage Limits For SSTs}

Provide, to the Department of Ecology, a preliminary assessment report for projected SST leakage. Such assessment to project expected environmental contamination and groundwater health risk using existing waste data. The report shall be included as Appendix C, Preliminary Risk-Based Leakage Thresholds for Hanford SSTs, of WHC-SD-WM-FRD-020, Functions and Requirements for Hanford Single-shell Tank Leakage Detection and Monitoring.

Leakage limits for SSTs are presently - TBD.

Source: $\quad$ TPA M-45-08-T01

TWRS F\&R Performance Requirement - Leakage Limits for SSTs

Issue: Current function constraints address tank leakage with respect to hazardous and radioactive wastes. However, the direct application of these constraints may not be feasible under certain retrieval/transfer architectures, thus appropriate leakage limits must be derived (and probably negotiated with appropriate agencies) and established as performance requirements. These derived leakage limits are important to the further selection of architecture strategies and processes. Without established limits or an acceptable strategy with defined risks to derive these limits, certain retrieval technologies may be excluded from architecture considerations.

Required Analysis: Perform the necessary analysis to derive leakage limits for SSTs

\subsubsection{System Capability Relationships}

\subsection{Definition of Operating Modes}

\subsection{Start-up/Testing}

Start-up and testing requirements are common to both SSTs and DSTs and are detailed in Chapter 1.

\subsection{Operations}




\section{Additions to SST Waste}

At no time shall waste be added to an SST.

Process condensate from tanks on active ventilation is not considered to be a waste or water addition, and therefore, can be returned to one of the tanks on the ventilation system per SD-WM-SAR-006, paragraph 7.5.

Raw water additions controlled by Section 13.2.3.B are specifically excluded from this specification.

Source: OSD-T-151-000013, Operating Specification for Single-shell Waste

\section{Dome Loading}

The static dome loading shall not exceed the equivalent maximum depth of soil above the tanks measured at the center (crown) of the tank dome and the live load shall not exceed the maximum value as described in the Table $2-2$ below in order to prevent structural damage to tank domes.

Table 2-2. Maximum Soil Depth/Live Loads Above Tanks.

\begin{tabular}{|c|c|c|}
\hline 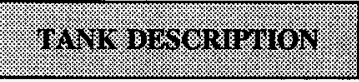 & 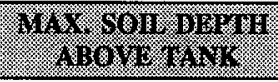 & 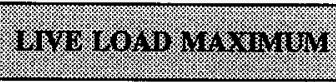 \\
\hline \multicolumn{3}{|c|}{ Single-shell Waste Storage Tanks (A, AX, B, BX, BY, C, S, SX, T, TX, TY and U) } \\
\hline 200 Series Tanks ( $20 \mathrm{ft} . \mathrm{dia})$ & $12 \mathrm{ft}$. & 50 tons \\
\hline 100 Series Tanks $(75 \mathrm{ft}$. dia.) & $10 \mathrm{ft}$. & 100 tons \\
\hline
\end{tabular}

Source: OSD-T-151-00013, Section 13.2.1C

\subsection{Decontamination and Decommissioning}

The requirements for decommissioning and decontamination are common to both SSTs and DSTs and are detailed in Chapter 1.

\subsection{Operating Modes Schedule}

\subsection{Near-term SST Capital Funding}

Near-term fiscal year capital funding for SST retrieval shall be minimized and should not exceed - TBD.

Source: $\quad$ TWRS F\&R Performance Requirement - Near-term SST Capital Funding 
Issue: A conservative projection of expected near-term capital funding for SST retrieval is needed to assure that the retrieval systems will be available when needed.

Required Analysis: Develop a conservative projection of expected near-term capital funding scenario for SST retrieval (i.e., through 2005).

\subsection{SST Retrieval Schedule}

This provides for an annual update of an SST retrieval sequence document that will define the tank selection criteria, tank selection rationale, reference retrieval method(s) for each tank, and the estimated retrieval schedules. The annual updates will be submitted to Ecology for approval. Updates are required each year from 1996 onwards.

Issue: A schedule defining when SST waste needs to be retrieved has not been prepared to show how retrieval will support the disposal program needs. This schedule can be prepared either in conjunction with or subsequent to the Tank Waste Retrieval Schedule. This schedule will form a basis for the SST retrieval sequence and project definition.

Required Analysis: Prepare the Tank Waste Retrieval Schedule.

Source: $\quad$ TPA M-45-02 (including Sections A to D)

\subsection{Complete SST Waste Retrieval}

Complete waste retrieval from all remaining Single-Shell Tanks by 9/30/2018. Retrieval standards and completion definitions are provided under the major milestone. The schedule reflects retrieval activities on a farm-by-farm basis. It also allows flexibility to retrieve tanks from various farms if desired to support safety issue resolution, pretreatment or disposal feed requirements, or other priorities.

Source: $\quad$ TPA M-45-05

DOE Proposed Operating Schedule - Retrieval Phase II

\subsubsection{External Interface Requirements}

The majority of external interface requirements are common to both SSTs and DSTs and are detailed in Chapter 1. This Section provides those interface requirements which are specific to SSTs.

\subsection{Input: SST Waste for Retrieval}

Wastes stored in underground SSTs which are to be retrieved for treatment, safety issue resolution, or disposal purposes. This waste includes saltcake, sludge, and in-tank hardware. In-tank hardware and discrete sources will be dispositioned by the Hanford Site function "Remediate Solid Waste". 


\subsection{SST Waste for Retrieval Requirements}

The volume of SST waste that will be retrieved for disposal is approximately 136,800 cubic meters (36 million gallons) of wastes. Transfer of liquids from the SSTs for concentration and storage in the DSTs may slightly alter the volume of tank waste for retrieval. This estimate of SST waste for retrieval does not include any fluid added to mobilize and transfer these wastes.

Source: $\quad$ TWRS F\&R Performance Requirement - Volume of SST Waste for Retrieval

\subsection{Input: Tank Operations Information}

Retrieve waste requires tank operations information consisting of monitoring and surveillance data which includes: in-tank temperature measurements, pressure measurements, waste level measurements, photographs, emission monitoring data, data from specialty equipment, as well as information related to the structure of the tank and its safety status. Tank operations information is provided by the Store Managed Tank Waste (sub-function Manage System Information) function.

\subsection{Tank Operations Information Requirements}

The waste storage facility shall transfer waste that does not exceed the temperature limits of at least $82.2^{\circ} \mathrm{C}\left(180^{\circ} \mathrm{F}\right)$ and up to $149^{\circ} \mathrm{C}\left(300^{\circ} \mathrm{F}\right)$. Maximum temperatures will vary based on the storage facility that the waste will be sent to.

Source: $\quad$ TWRS F\&R Performance Requirement - Transfer System Temperature Ranges Operations Information

\subsection{Input: Tank Waste Characterization Information}

Tank Waste Characterization Information consists of waste analysis data packages, waste in-situ measurement data, and other statistical data analysis.

\subsection{Tank Waste Characterization Information Requirements}

Tank waste type for SST wastes is TBD.

Issue: The compatibility of retrieved SST wastes for storage in the DST system has not been assessed.

Required Analysis: The compatibility of retrieved SST wastes needs to be determined for storage in the double-shell tank system.

Source: $\quad$ TWRS F\&R Performance Requirement - Tank Waste Type (SST Wastes) 


\subsection{Input: Historical SST Leakage Information}

Historical information about past SST leakage and soil contamination plumes. This information consists of migration paths, leakage volumes, leakage depths, etc..

\subsection{Output: Closure-ready SSTs}

SSTs from which sufficient waste has been retrieved to meet closure requirements.

\subsection{Closure-ready SST Requirements}

The waste retrieval system shall reduce the waste inventory to a maximum heel of $360 \mathrm{cu} . \mathrm{ft}$. in 100 series and $30 \mathrm{cu}$. ft. in 200 series SSTs or limit of waste retrieval technology, whichever is less.

Source: TWRS F\&R Performance Requirement - Allowable Heel - Retrieval -SST

Closure will follow retrieval of as much tank waste as technically possible, with tank waste residues not to exceed 360 cubic feet (cu. ft.) in each of the 100 series tanks, $30 \mathrm{cu}$. $\mathrm{ft}$. in each of the 200 series tanks, or the limit of waste retrieval technology capability, whichever is less.

Source: TWRS F\&R Performance Requirement - Residual Volume for Closure

Complete closure of all single-shell tank farms will be by 9/30/2024 .

The single-shell tank closure work plan will be prepared describing the work integration process for single-shell tank closures and status of work and integration process. Known issues will be identified and an explanation will be given on how these issues are being addressed. This work plan will be provided to Ecology for review/comment and will be used as a roadmap for closure of the single-shell tanks. Because of the uncertainties in the closure process, the work plan will evolve as these uncertainties are resolved and eventually it will become the SST closure/post-closure plan(s) issued for Ecology's approval under subsequent TPA interim milestones. Major work areas covered in the work plan will include waste retrieval, operable units characterization, technologies development to support closure, regulatory pathway and strategy for achieving closure.

Source: TPA M-45-06

\subsection{Output: Retrieved Tank Waste}

Waste retrieved and transferred to another facility for interim storage and feed staging.

\subsection{Retrieved Tank Waste Requirements}

The SST waste retrieval rate must average approximately 21 cubic meters per day of SST 
waste. This waste retrieval rate is a linear assumption, will vary over time, and does not include solutions (if any) added to mobilize the SST wastes.

Source: $\quad$ TWRS F\&R Performance Requirement - SST Waste Retrieval Rate

\subsubsection{Physical Characteristics}

The SST retrieval system will be located in the 200 area of the Hanford site. Details of the site boundary and land use restrictions are given in Chapter 1.

\subsubsection{System Quality Factors}

The requirements for the reliability, maintainability, availability, and other quality factors for the system are common to both SSTs and DSTs and are detailed in Chapter 1.

\subsubsection{Environmental Conditions}

Environmental conditions for the Hanford site are given in Chapter 1.

\subsubsection{Transportability}

Reserved

\subsubsection{Flexibility and Expansion}

The requirements for flexibility and expansion for the system are common to both SSTs and DSTs and are detailed in Chapter 1.

\subsubsection{Portability}

Reserved

\subsubsection{Design and Construction}

The design and construction requirements are common to both SSTs and DSTs and are detailed in Chapter 1.

\subsubsection{Singly Contained Tank Systems}

Singly contained tank systems shall not be used to store fresh high-level waste from fuel reprocessing operations except under emergency conditions as determined by the Operations Office Manager.

Source: DOE5820.2A, Chapter I, 3.c(2)(a) 


\subsubsection{Documentation}

Documentation requirements are common to both SSTs and DSTs and are detailed in Chapter 1.

\subsubsection{Logistics}

Prior to transfer of SST wastes to a DST receiving tank, the SST retrieval system operator shall confirm that there is sufficient capacity in the receiving tank for the transfer.

\subsubsection{Personnel and Training}

Personnel and training requirements are common to both SSTs and DSTs and are detailed in Chapter 1.

\subsubsection{Characteristics of Sub-System Elements}

The objective of the SST Retrieval Project is the retrieval of waste from SSTs and Miscellaneous Underground Storage Tanks (MUSTs) to permit closure of these tanks in accordance with regulatory requirements. The regulatory requirements for SSTs is retrieval of $99 \%$ of the waste volume. The regulatory requirement for retrieval from MUSTs will be determined upon completion of the identification of tanks and characterization of tank contents.

\subsubsection{Project W320: 241-C-106 Sluicing}

Sluicing will be demonstrated in the retrieval of sludge from 241-C-106 and the resolution of the high heat safety issue.

\section{Heat Source Reduction in 241-C-106 Waste Retrieval}

A sufficient quantity of waste must be removed from single-shell tank 241-C-106 so that the waste remaining in this tank does not require the addition of water to maintain the waste temperature below $300^{\circ} \mathrm{F}$ and to reduce the heat load in the tank to below $40,000 \mathrm{Btu} / \mathrm{hr}$.

Source: $\quad$ TWRS F\&R Performance Requirement - High Heat Source Tank Waste (106-C) Reduction (Derived from: DOE Secretary Direction of September 13, 1993 and OSD-T-151-00013, Rev. D-4). 


\section{Initiate 241-C-106 Accelerated Retrieval}

Initiate Tank 241-C-106 accelerated retrieval by October 1996 (accelerated12 months ahead of baseline schedule)

Source: TPA M-45-03A, DOE.SEC.DIR.B.6.A.4

Initiate Final Retrieval of 241-C-106

Initiate final retrieval of tank $241-\mathrm{C}-106$ by $6 / 30 / 2002$ to complete initial demonstration of SST retrieval technologies.

Source: $\quad$ TPA M-45-03-T02

\section{Complete SST Retrieval Technology Demonstration (241-C-106)}

Complete a full scale demonstration of SST retrieval technology by 9/30/2003. This demonstration will be considered complete when no less than $99 \%$ of the waste inventory is removed from the tank (241-C-106).

Source: TPA M-45-03-T01

\subsubsection{Initial Single-Shell Tank Retrieval System (ISSTRS) Project}

Performance data acquired in sluicing 241-C-106 will be applied to the system definition, design, and construction of the ISSTRS, the objective of which is to demonstrate retrieval of a broader range of tank wastes including saltcake.

\section{Conceptual Design For ISSTRS}

Complete conceptual design for the initial SST retrieval systems by $4 / 30 / 1997$.

Source: $\quad$ TPA M-45-04A

\section{Detailed Design For ISSTRS}

Complete design for the initial SST retrieval systems by 12/31/2000.

Source: $\quad$ TPA M-45-04-T02

\section{Construction For ISSTRS}

Complete construction for the initial SST retrieval systems by 6/30/2003.

Source: $\quad$ TPA M-45-04-T03 


\section{Complete Testing of ISSTRS}

Complete construction and related testing of the initial SST retrieval systems by 11/30/2003 . This milestone will provide retrieval systems for an entire Single-Shell Tank farm or an equivalent number of tanks.

Source: $\quad$ TPA M-45-04-T01

\subsubsection{Acquire Commercial Technology for Retrieval}

The reference technology for SST retrieval is the sluicing process that was successfully demonstrated at the Hanford site in the 1950's through the 1970 's. However, sluicing alone will not accomplish the objective to remove $99 \%$ of the SST waste. Enhancements to sluicing and alternate retrieval technologies will be identified and developed in partnership with industry through Acquire Commercial Technology for Retrieval (ACTR). The ACTR will be used in all the SST retrieval projects.

\subsubsection{Hanford Tank Initiative (HTI)}

The objective of the HTI will be to demonstrate heal removal and closure of SSTs. Project details for HTI are yet to be defined.

\subsubsection{Precedence}

The hierarchical relationships among the SST and DST requirements are common and are detailed in Chapter 1.

\subsubsection{Qualification}

Reserved 
Figure 2-3. Single-Shell Tank Waste Retrieval Sub-System Elements.

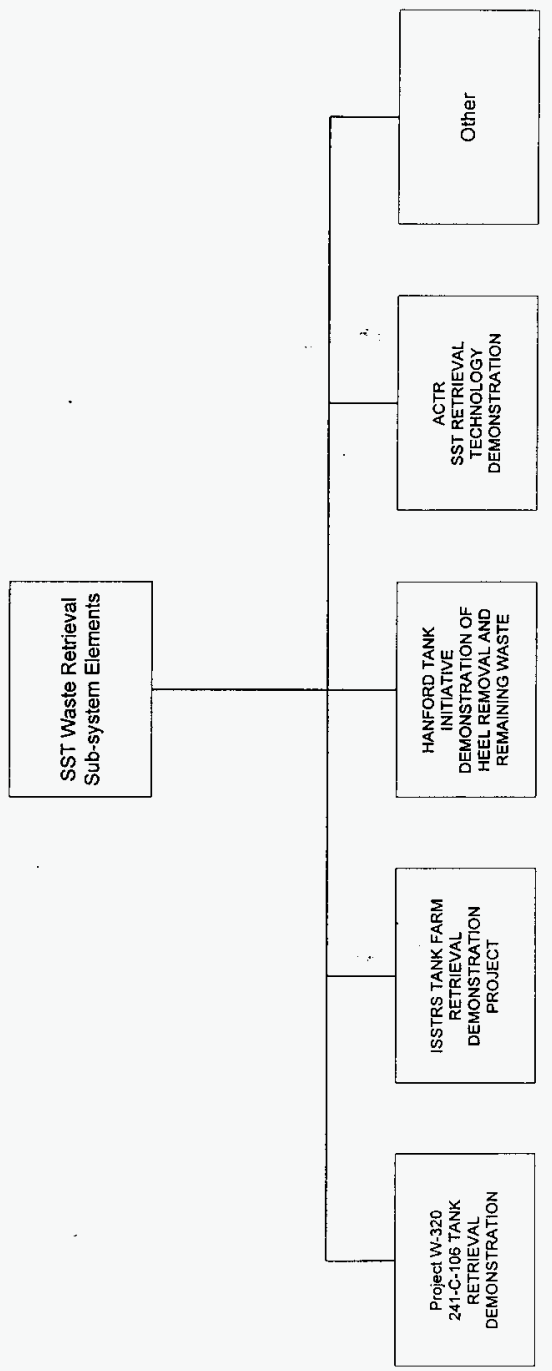




\subsubsection{Standard Sample}

Reserved

\subsection{QUALITY ASSURANCE PROVISIONS}

Quality assurance provisions are common to both SSTs and DSTs and are detailed in Chapter 1.

\subsubsection{Responsibility for Inspections}

Responsibility for inspections are common to both SSTs and DSTs and are detailed in Chapter 1.

\subsubsection{Special Tests and Examinations}

Table 2-3 correlates the requirements of Section 2.3 with the method to be used to comply with the requirements. Documentation of compliance will be accomplished through the use of detailed procedures to be developed and performed on all procured, constructed, and developed equipment, structures, and software.

The methods of compliance to be used are:

A. Analysis. Analysis is the process needed to verify a requirement by rational thinking, tradeoff studies, modeling, and processing test data and accumulated results to reach a conclusion. Analysis involves the processing of accumulated results and conclusions, intended to provide proof that verification of a requirement has been accomplished. The analytical results may be comprised of a compilation or interpretation of existing information or derived from lower level examinations, tests, demonstrations, or analyses.

B. Examination. Examination is the process of investigating a product to verify that required features are incorporated. Examination consists of investigation, without the use of special laboratory appliances, procedures, supplies, or services, to determine conformance to those specified requirements which can be determined by such investigations. Examination is generally nondestructive and includes, but is not limited to, visual, auditory, olfactory, tactile, and other investigations; simple physical manipulation; gauging; and measurement.

C. Test. Test is the quantitative process whereby data is collected over a specified time period, under controlled conditions, in order to document the as-built performance of a product. A test denotes the determination of the properties or elements of items (or 
components thereof) by technical means, including functional operation, the application of established principles and procedures and the collection of quantitative data. The analysis of data derived from testing is an integral part of the method.

D. Demonstration. Demonstration is the qualitative process of exercising a product to verify its operability, where data may or may not be collected. Demonstration differs from test by directness of approach in the verification of a requirement and is accomplished without the use of instrumentation or special equipment. Thus, operation of a representative item in or near its use environment would be defined as a Demonstration rather than a Test. Demonstration attempts to verify, qualitatively, the performance of a function, where as Test involves verifying performance within a specific range of measurement.

When more than one method of compliance is marked in Table $2-3$, compliance must be verified by one or more of the methods marked.

Table 2-3. Verification Matrix. (3 sheets)

\begin{tabular}{|c|c|c|c|c|c|c|}
\hline Sectoo 2.30 & Tilie & Wa & 4 & E & I. & D \\
\hline 2.3 .2 .1 & Performance Characteristics & $\mathrm{X}$ & & & & \\
\hline 2.3 .2 .1 .1 & $\begin{array}{l}\text { Allowable Heel Following Retrieval } \\
\text { From SSTs }\end{array}$ & & $\mathrm{X}$ & & & \\
\hline 2.3 .2 .1 .2 & SST Waste Retrieval Rate & & $\mathrm{X}$ & & & \\
\hline 2.3 .2 .1 .3 & Complete Closure of SSTs & & $X$ & & & \\
\hline 2.3 .2 .1 .4 & Retrieval Method Selection & & & & & $\mathrm{X}$ \\
\hline 2.3 .2 .1 .5 & Waste Minimization/Volume Reduction & & $\mathrm{X}$ & & & \\
\hline 2.3 .2 .1 .6 & Waste Compatibility/Segregation & & $\mathrm{X}$ & & $\mathrm{X}$ & \\
\hline 2.3 .2 .1 .7 & Leakage Limits for SSTs & & $\mathrm{X}$ & & & \\
\hline 2.3 .2 .2 & System Capability Relationships & $\mathrm{X}$ & & & & \\
\hline 2.3 .2 .2 .1 & Definition of Operating Modes & $\mathrm{X}$ & & & & \\
\hline 2.3 .2 .2 .1 .1 & Start-up/Testing & & & & $\mathrm{X}$ & \\
\hline 2.3 .2 .2 .1 .2 & Operations & & & & $\mathrm{X}$ & \\
\hline 2.3 .2 .2 .1 .3 & Decontamination and Decommissioning & $\mathrm{X}$ & & & & \\
\hline 2.3 .2 .2 .2 & Operating Modes Schedule & & $\mathrm{X}$ & & & \\
\hline 2.3 .2 .2 .2 .1 & Near-term SST Capital Funding & & $\mathrm{X}$ & & & \\
\hline 2.3 .2 .2 .2 .2 & SST Retrieval Schedule & & $\mathrm{X}$ & & & \\
\hline 2.3 .2 .2 .2 .3 & Complete SST Waste Retrieval & & $\mathrm{X}$ & & & \\
\hline 2.3 .2 .3 & External Interface Requirements & $X$ & & & & \\
\hline
\end{tabular}


Table 2-3. Verification Matrix. (3 sheets)

\begin{tabular}{|c|c|c|c|c|c|c|}
\hline $\begin{array}{l}\text { Section } 2,3.0 \\
\text { Paragraph }\end{array}$ & 1.: & NOW & 1. & I: & ? & (1) \\
\hline 2.3 .2 .3 .1 & SST Waste for Retrieval (Input) & & $\mathrm{X}$ & & & \\
\hline 2.3.2.3.1.1 & SST Waste for Retrieval Requirements & & $\mathrm{X}$ & & & \\
\hline 2.3.2.3.2 & Tank Operations Information (Input) & & $\mathrm{X}$ & & $\mathrm{X}$ & \\
\hline 2.3.2.3.2.1 & \begin{tabular}{|l|} 
Tank Operations Information \\
Requirements
\end{tabular} & & $\bar{X}$ & & $\mathrm{X}$ & \\
\hline 2.3.2.3.3 & $\begin{array}{l}\text { Tank Waste Characterization } \\
\text { Information (Input) }\end{array}$ & & $\bar{X}$ & & $\mathrm{X}$ & \\
\hline 2.3.2.3.4 & Historical SST Leakage Information & & $\bar{X}$ & & $\mathrm{X}$ & \\
\hline 2.3 .2 .3 .5 & Closure-ready SSTs (Output) & & $\mathrm{X}$ & & & \\
\hline 2.3 .2 .3 .5 .1 & Closure-ready SST Requirement & & $\mathrm{X}$ & & & \\
\hline 2.3 .2 .3 .6 & Retrieved Tank Waste (Output) & & $X$ & & $\mathrm{X}$ & \\
\hline 2.3 .2 .3 .6 .1 & Retrieved Tank Waste Requirements & & $\mathrm{X}$ & $\mathrm{X}$ & $\mathrm{X}$ & \\
\hline 2.3.2.4 & Physical Characteristics & $\mathrm{X}$ & & & & \\
\hline 2.3 .2 .5 & System Quality Factors & $\mathrm{X}$ & & & & \\
\hline 2.3 .2 .6 & Environmental Conditions & $\mathrm{X}$ & & & & \\
\hline 2.3 .2 .7 & Transportability (Reserved) & $\mathrm{X}$ & & & & \\
\hline 2.3 .2 .8 & Flexibility and Expansion & & & & $\mathrm{X}$ & $\mathrm{X}$ \\
\hline 2.3 .2 .9 & Portability (Reserved) & $\mathrm{X}$ & & & & \\
\hline 2.3 .3 & Design and Construction & & & & & $\mathrm{X}$ \\
\hline 2.3 .3 .1 & Singly Contained Tank Systems & & & $\mathrm{X}$ & & \\
\hline 2.3 .4 & Documentation & & $\mathrm{X}$ & & & \\
\hline 2.3 .5 & Logistics & & $\mathrm{X}$ & $\mathrm{X}$ & & \\
\hline 2.3 .6 & Personnel and Training & & $\mathrm{X}$ & & + & \\
\hline 2.3 .7 & Characteristics of Sub-system Elements & $\mathrm{X}$ & & & & \\
\hline 2.3.7.1 & Project W320: 241-C-106 sluicing & & & & $\mathrm{X}$ & $\mathrm{X}$ \\
\hline 2.3 .7 .2 & ISSTRS Project & & $\mathrm{X}$ & & $\mathrm{X}$ & $\mathrm{X}$ \\
\hline 2.3 .7 .3 & ACTR & & $\mathrm{X}$ & & $\mathrm{X}$ & $\mathrm{X}$ \\
\hline 2.3 .7 .4 & HTI & & $\mathrm{X}$ & & $\mathrm{X}$ & $\mathrm{X}$ \\
\hline 2.3 .8 & Precedence & $\mathrm{X}$ & & & & \\
\hline 2.3 .9 & Qualification (Reserved) & $\mathrm{X}$ & & & & \\
\hline 2.3 .10 & Standard Sample (Reserved) & $\mathrm{X}$ & & & & \\
\hline 2.4 & Quality Assurance Provisions & & $\mathrm{X}$ & & & \\
\hline
\end{tabular}


Table 2-3. Verification Matrix. (3 sheets)

\begin{tabular}{|c|c|c|c|c|c|c|}
\hline 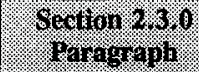 & Wiag & Was & 4 & 站 & (3. & (1) \\
\hline 2.4 .1 & Responsibility For Inspections & & $\mathrm{X}$ & $\mathrm{X}$ & $\mathbf{X}$ & \\
\hline 2.4 .2 & Special Tests and Examinations & & & & $\mathbf{X}$ & $\mathrm{X}$ \\
\hline 2.4 .3 & Requirements Traceability Matrix & $\mathrm{X}$ & & & & \\
\hline 2.5 & $\begin{array}{l}\text { Preparation for Delivery (or Operations) } \\
\text { (Reserved) }\end{array}$ & $\mathrm{X}$ & & & & \\
\hline 2.6 & Notes & $\mathrm{X}$ & & & & \\
\hline
\end{tabular}

Notes:

$\begin{array}{ll}\text { N/A - Not applicable } & \text { E - Examination D - Demonstration } \\ \text { A - Analysis } & \text { T - Testing }\end{array}$

\subsubsection{Requirements Traceability Matrix}

See Table 2-4 below.

\subsection{PREPARATION FOR DELIVERY (OR OPERATIONS)}

Reserved.

Table 2-4. Requirements Traceability Matrix. (3 sheets)

\begin{tabular}{|c|c|c|}
\hline $\begin{array}{l}\text { Segtion } 2 \text { r } \\
\text { Paragrah }\end{array}$ & Roguiriman lo & Hescription \\
\hline \multicolumn{3}{|c|}{ Performance Requirements } \\
\hline 2.3 .2 .3 .5 .1 & POCH.A.2.SST & Allowable Heel - Retrieval - SST \\
\hline 2.3 .2 .1 .4 & WHC-SD-WM-FRD-020 & Clean Out Requirements for SSTs \\
\hline 2.3 .2 .2 .2 .3 & POCH.D.2 & $\begin{array}{l}\text { DOE Proposed Operating Schedule - } \\
\text { Retrieval Phase } 2\end{array}$ \\
\hline 2.3 .7 .1 & DOE.SEC.DIR.B.6.A.4 & DOE Secretary Direction B.6.A.4 \\
\hline 2.3 .3 .1 & DOE.5820.2A, Chapter I, 3.c(2)(a) & Singly Contained Tank Systems \\
\hline 2.3 .7 .1 & WHC-SD-WM-FRD-020 & $\begin{array}{l}\text { High Heat Source Tank Waste (106-C) } \\
\text { Reduction }\end{array}$ \\
\hline 2.3 .2 .1 .8 & WHC-SD-WM-FRD-020 & Leakage Limits for SSTs \\
\hline 2.3 .2 .2 .2 .1 & WHC-SD-WM-FRD-020 & Near-term SST Capital Funding \\
\hline
\end{tabular}


Table 2-4. Requirements Traceability Matrix. (3 sheets)

\begin{tabular}{|c|c|c|}
\hline $\operatorname{sectan} 20$ & Rrquirenient No. & bescosing \\
\hline 2.3 .2 .2 .1 .2 & OSD-T-151-000013 & $\begin{array}{l}\text { Operating Specification for Single-shell } \\
\text { Waste Storage Tanks, P. 17, Section 13.2.3 } \\
\text { (A) }\end{array}$ \\
\hline 2.3 .2 .2 .1 .2 & OSD-T-151-00013 & Section $13.2 .1 \mathrm{C}$ \\
\hline 2.3 .2 .3 .3 .1 & WHC-SD-WM-FRD-020 & SST Waste Characterization Requirements \\
\hline 2.3 .7 .1 & WHC-SD-WM-FRD-020 & $\begin{array}{l}\text { SST Waste Retrieval Demonstration - Tank } \\
\text { Selection }\end{array}$ \\
\hline 2.3 .2 .3 .5 .1 & WHC-SD-WM-FRD-020 & Residual Volume for Closure \\
\hline 2.3 .2 .3 .6 .1 & WHC-SD-WM-FRD-020 & SST Waste Retrieval Rate \\
\hline 2.3 .2 .2 .2 .2 & WHC-SD-WM-FRD-020 & SST Waste Retrieval Schedule \\
\hline 2.3.2.1.4 & WHC-SD-WM-FRD-020 & Select Retrieval Method \\
\hline 2.3 .2 .3 .3 .1 & WHC-SD-WM-FRD-020 & Tank Waste Type \\
\hline 2.3 .2 .3 .2 .1 & WHC-SD-WM-FRD-020 & $\begin{array}{l}\text { Transfer System Temperature Ranges } \\
\text { Operations Information }\end{array}$ \\
\hline 2.3 .2 .1 .3 & TPA CCF M-45-00 & Complete closure of SSTs \\
\hline 2.3 .2 .1 .5 & TPA CCF M-45-01 & Develop SST retrieval technology \\
\hline 2.3 .2 .2 .2 .2 & TPA CCF M-45-02 & Retrieval sequence document \\
\hline 2.3.2.2.2.2 & TPA CCF M-45-02.A & Submit initial RS doc. (1996) \\
\hline 2.3 .2 .2 .2 .2 & TPA CCF M-45-02.B & Submit annual RS doc. (1997) \\
\hline 2.3.2.2.2.2 & TPA CCF M-45-02.C & Submit annual RS doc. (1998) \\
\hline 2.3 .2 .2 .2 .2 & TPA CCF M-45-02.D & Submit annual RS doc. (1999) \\
\hline 2.3 .7 .1 & TPA CCF M-45-03.A & Initiate $\mathrm{C} 106$ retrieval \\
\hline 2.3 .7 .1 & TPA CCF M-45-03.T01 & Complete retrieval demo \\
\hline 2.3 .7 .1 & TPA CCF M-45-03.T02 & Initiate $\mathrm{C} 106$ final retrieval \\
\hline 2.3 .7 .2 & TPA CCF M-45-04.A & Complete CD for retrieval \\
\hline 2.3 .7 .2 & TPA CCF M-45-04.T01 & Complete testing ISSTRS (2003) \\
\hline 2.3 .7 .2 & TPA CCF M-45-04.T02 & Complete design of ISSTRS (2000) \\
\hline 2.3 .7 .2 & TPA CCF M-45-04.T03 & Complete const. ISSTRS (2003) \\
\hline 2.3 .2 .2 .2 .3 & TPA CCF M-45-05 & Complete SST retrieval (2018) \\
\hline 2.3 .2 .1 .2 & TPA CCF M-45-05.T01 & Initiate SST retrieval (2003) \\
\hline 2.3 .2 .1 .2 & TPA CCF M-45-05.T02 & Initiate SSTs 2 and 3 (2004) \\
\hline 2.3 .2 .1 .2 & TPA CCF M-45-05.T03 & Initiate SSTs 4,5 , and $6(2005)$ \\
\hline
\end{tabular}


Table 2-4. Requirements Traceability Matrix. (3 sheets)

\begin{tabular}{|c|c|c|}
\hline Gerrom 2, & 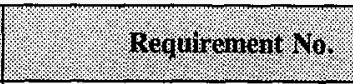 & $\operatorname{soc} 0 \mathrm{prom}$ \\
\hline 2.3 .2 .1 .2 & TPA CCF M-45-05.T04 & Initiate SSTs 7,8,9, and 10 (2006) \\
\hline 2.3 .2 .1 .2 & TPA CCF M-45-05.T05 & Next 5 SSTs (2007) \\
\hline 2.3 .2 .1 .2 & TPA CCF M-45-05.T06 & Next 5 SSTs (2008) \\
\hline 2.3 .2 .1 .2 & TPA CCF M-45-05.T07 & Next 7 SSTs (2009) \\
\hline 2.3 .2 .1 .2 & TPA CCF M-45-05.T08 & Next 8 SSTs $(2010)$ \\
\hline 2.3 .2 .1 .2 & TPA CCF M-45-05.T09 & Next 10 SSTs (2011) \\
\hline 2.3 .2 .1 .2 & TPA CCF M-45-05.T10 & Next 12 SSTs (2012) \\
\hline 2.3 .2 .1 .2 & TPA CCF M-45-05.T11 & Next 14 SSTs (2013) \\
\hline 2.3 .2 .1 .2 & TPA CCF M-45-05.T12 & Next 17 SSTs (2014) \\
\hline 2.3 .2 .1 .2 & TPA CCF M-45-05.T13 & Next 20 SSTs (2015) \\
\hline 2.3 .2 .1 .2 & TPA CCF M-45-05.T14 & Next 20 SSTs (2016) \\
\hline 2.3 .2 .1 .2 & TPA CCF M-45-05.T15 & Next 20 SSTs (2017) \\
\hline 2.3 .2 .3 .5 .1 & TPA CCC M-45-06 & Complete Closure of SSTs \\
\hline 2.3 .2 .1 .3 & TPA CCC M-45-06.T01 & Submit Post Closure Plan (2004) \\
\hline 2.3 .2 .1 .3 & TPA CCC M-45-06.T02 & Issue Final Closure Plan (2006) \\
\hline 2.3 .2 .1 .3 & TPA CCC M-45-06.T03 & Initiate Closure Actions (2012) \\
\hline 2.3 .2 .1 .3 & TPA CCC M-45-06.T04 & Complete Closure Actions (2014) \\
\hline 2.3 .2 .1 .7 & TPA CCF M-45-08-T01 & SST Leakage Limits \\
\hline 2.3.2.3.1.1 & WHC-SD-WM-FRD-020 & Volume of SST Waste for Retrieval \\
\hline \multicolumn{3}{|l|}{ Input/Output } \\
\hline 2.3 .2 .3 .1 & Input & SST Waste Retrieval \\
\hline 2.3 .2 .3 .2 & Input & Tank Operations Information \\
\hline 2.3 .2 .3 .3 & Input & Tank waste Characterization Information \\
\hline 2.3 .2 .3 .4 & Input & Historical SST Leakage Information \\
\hline 2.3 .2 .3 .5 & Output & Closure-Ready SSTs \\
\hline 2.3 .2 .3 .6 & Output & Retrieved Tank Waste \\
\hline
\end{tabular}


WHC-SD-WM-TRD-004, Rev. 0

This page intentionally left blank.

$2 \cdot 26$ 


\subsection{TECHNICAL REQUIREMENTS SPECIFICATION FOR DOUBLE-SHELL TANK RETRIEVAL - FUNCTION 4.2.2.2}

\subsection{SCOPE}

This chapter provides the technical requirements specification for the retrieval of waste from the double-shell underground storage tanks at the Hanford Site. All activities covered by this scope are conducted in support of the Tank Waste Remediation System (TWRS) mission.

\subsubsection{Identification}

Program: Tank Waste Remediation System

Project: Double-Shell Tank (DST) Waste Retrieval System

\subsubsection{Double-Shell Tank Waste Retrieval System Overview}

The DST waste retrieval system is a major architecture element of the Tank Waste Remediation System (TWRS). The waste retrieval system mobilizes sludge, and solids contained within the Hanford Site tanks waste storage system which consists of mixed waste underground storage tanks and ancillary equipment. The vast majority of the waste is considered high-level waste (HLW) by definition.

After mobilization, the tank waste sludges and solids are transported to the waste processing system for treatment. The waste retrieval system also provides the means to transfer waste from the waste storage system. To the extent practical, the waste retrieval system shall use existing components of the waste transfer system (e.g., underground piping, diversion boxes, and valve pits) to transfer mobilized tank waste to the processing system.

Tank space management constitutes a major interface between the tank waste system and waste retrieval system. The TWRS has 28 DSTs with about $120,000 \mathrm{~m}^{3}$ of capacity. To manage, the waste within this capacity requires TWRS to transfer waste among the tanks. The waste retrieval system provides equipment to consolidate waste sludges as part of the overall waste management actions of the Tank Waste System architecture.

Demonstration of tank waste retrieval technology is necessary to verify selected architectures can achieve established system performance requirements, thereby reducing program uncertainties and risks. 


\subsubsection{Chapter Overview}

This preliminary system specification has been prepared using the format guidelines of military standard (MIL-STD) 490; system/segment specification. All Sections specified in MIL-STD-490 have been included in this chapter. In keeping with the conventions of MIL-STD-490, if a Section is not applicable for this specification, the Section title is provided followed by a statement identifying the Section as not applicable.

\subsection{APPLICABLE DOCUMENTS}

System specification requirements, identified in Sections 3.3 and 3.4, for accomplishing the DST waste retrieval system mission have been developed from many source documents. A requirements traceability matrix is provided in Table 3-5 identifying the source for each DST retrieval system specification. These sources come from both government and non-government sources. A definition of government and non-government sources is given in Chapter 1.

\subsection{SYSTEM REQUIREMENTS}

\subsubsection{System Definitions}

The Tank Waste Remediation System Function and Requirements established function 4.2.2.2 Retrieve DST Waste. This function is defined as: The removal of wastes (i.e., saltcake, sludges, in-tank hardware, and discrete sources) from double-shell tanks (DSTs) and the transfer of these wastes to the Store In-Process Waste function. Wastes will be removed to the extent required for turnover of the tanks to closure. The function includes retrieval and consolidation of tank space. The function Retrieve Tank Waste has been decomposed into the following functions. Figure 3-1 represents the function breakdown structure for retrieve DST Waste.

4.2.2.1 Mobilize DST Waste. The dislodging or breaking up of sludges in the DSTs to facilitate their transfer from the tanks. In-Tank Hardware will be removed to the extent required to permit waste sludge mobilization.

4.2.2.2 Transfer DST Waste. The movement of wastes removed from DSTs to the Store In-Process Waste function. When complete these tanks may be used by the Store In-Process waste function for interim storage. 
Figure 3-1. Double-Shell Tank Waste Retrieval Functional Breakdown Structure.

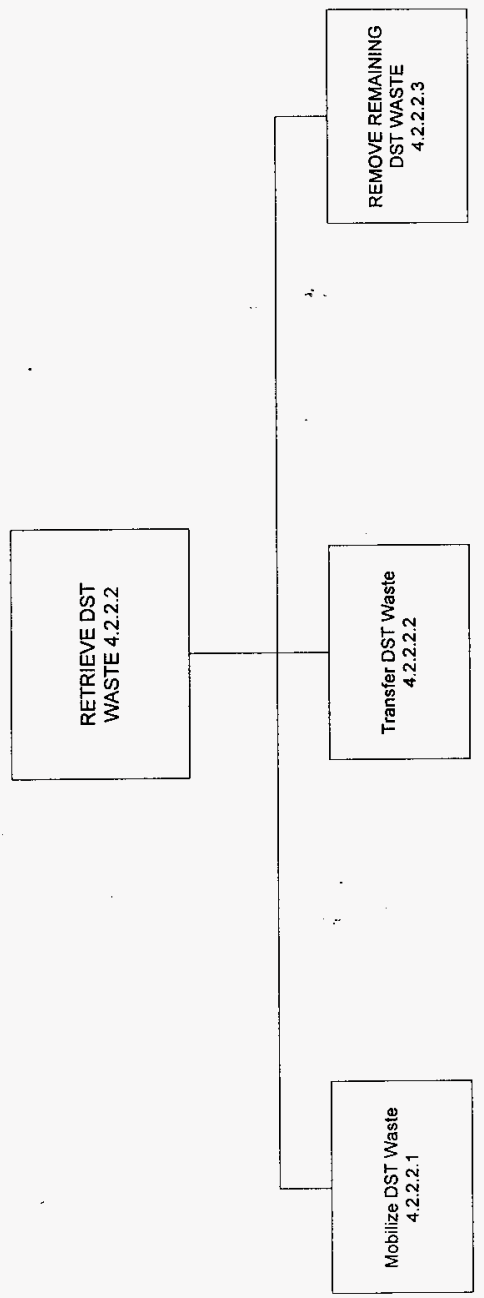


4.2.2.2.3 Remove Remaining DST Waste. The removal of waste left in the DSTs when no longer needed by the Store In-Process Waste function and the transfer of these wastes to a storage or treatment facility. Wastes will be removed to the extent required for turnover of the tanks to closure.

\subsubsection{Interface Description}

This Section provides a diagram of the system interfaces. Figure 3-2 represents N-Square diagram for retrieve DST waste.

\subsubsection{Risk Assumptions}

Table 3-1 lists the major program risk assumptions applicable to the DST Waste Retrieval system.

Table 3-1. Risk Assumptions.

\begin{tabular}{|l|l|}
\hline \multicolumn{1}{|c|}{ Risk Assumptions } & \multicolumn{1}{|c|}{ Poteatial Consequence } \\
\hline $\begin{array}{l}\text { Sufficient funds not available to completely } \\
\text { immobilize all DST waste by } 2028 .\end{array}$ & $1 . \quad$ Unplanned delay in tank \\
\hline
\end{tabular}

\subsubsection{Characteristics}

Performance and physical characteristics contained in this Section are from requirements identified in the TWRS Function and Requirements document (WHC 1996). Performance requirements identified in the TWRS Functions and Requirements document were reviewed and associated with the appropriate characteristics Section of this specification. Constraints identified in the TWRS Functions and Requirements document were reviewed and transformed into system specification requirements. The complete text of performance requirements and constraints are contained in the TWRS Functions and Requirements document. Table 3-5 includes allocation of regulatory constraints and performance requirements to appropriate system and segment elements.

\subsubsection{Performance Characteristics}

This paragraph is divided into subparagraphs which describe the DST Waste Retrieval System capabilities in the context of the requirements that define the DST Retrieval System function. 


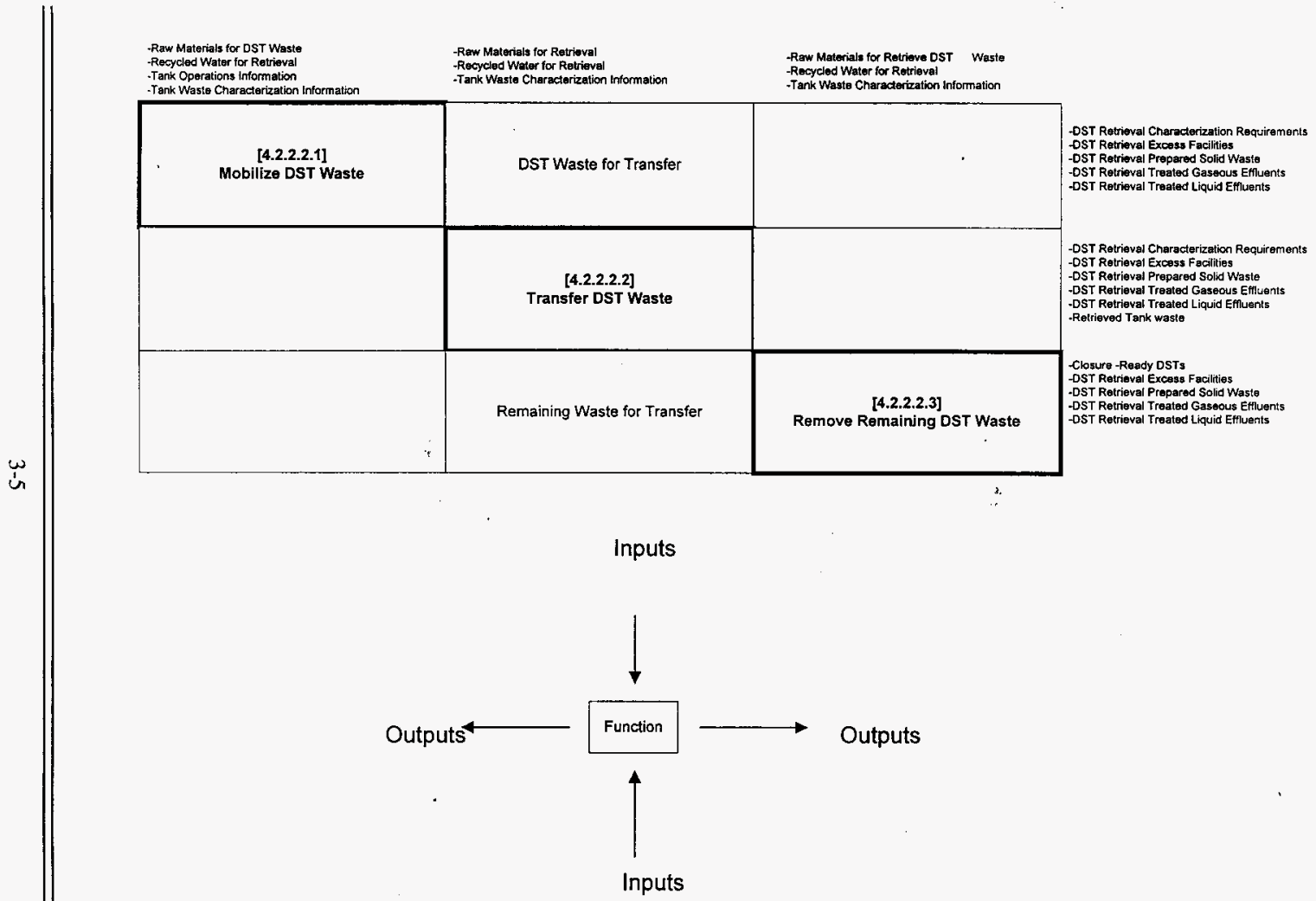




\subsection{Allowable Heel Following Retrieval From DSTs}

The waste retrieval system shall be capable of removing at least $99.95 \%$ of the waste from DSTs during terminal cleanout prior to final closure.

Source: HDW-EIS, Vol. 2, B.6

WAC 173-303-640-610

Issue: The allowable heel for DST retrieval has not been defined.

Required Analysis: Evaluate closure alternatives for DSTs and supplement the TWRS EIS.

\subsection{Allowable Heel in DSTs for Re-Use}

An evaluation has been conducted to determine the heel left in each DST after mobilization of sludges using two mixer pumps (WHC-SD-WM-TA-162). This evaluation used the available tank waste characterization information and tank sludge inventories. Based upon the evaluation presented in WHC-SD-WM-TA-162 (Double-Shell Tank Retrieval Allowable Heel Trade Study), pretreated LLW may only be stored in tanks 241-AN-105, 241-AP-101, 241-AP-102, 241-AP-103, 241-AP-104, 241-AP-105, 241-AP-106, 241-AP-107, and 241-AP-108. This evaluation is predicated upon these tanks not presently containing insoluble sludges. If insoluble sludges are added or if insoluble sludges are determined to be present in these tanks, then the use of these tanks for storage of pretreated LLW must be re-evaluated.

Source: $\quad$ TWRS F\&R Performance Requirement - Allowable Heel in DSTs for Re-Use

\subsection{Allowable Sludge Heel in 241-SY-102}

The waste retrieval system must reduce the TRU sludge volume in tank 241-SY-102 to less than 775 gallons, so that this tank may be used to receive complexed salt well solutions from 200 West area SSTs.

Source: Internal Memo \#73510-95-017

Internal Memo \#74D00-96-MEJ-002

\subsection{Retrieval Method Selection}

The primary method for removal of wastes from DST has not been selected. However, demonstrations of hydraulic methods (i.e., sluicing and mixer pumps) are planned for 241-AZ-101. Heel removal systems are under evaluation. The retrieval system for initial retrieval (Functions 4.2.2.2.1 and 4.2.2.2.2) is not required to meet the requirements for terminal cleanout (Function 4.2.2.2.3). 
Source: $\quad$ TWRS F\&R Performance Requirement - Select Retrieval Method

Issue: A variety of retrieval methods exist for removal of tank waste. Performance measures such as, environmental, public health and safety, regulatory compliance, technical feasibility, and life-cycle costs should be critical for retrieval technology selection. Additionally, the retrieval method must be able to remove the waste to extent required for turnover of the tanks for closure.

Required Analysis: An Alternative Generation Analysis (AGA) on selected retrieval method is being conducted.

\subsection{Waste Minimization/Volume Reduction}

Waste minimization/volume reduction requirements are common to both SSTs and DSTs and are detailed in Chapter 1.

\subsection{Waste Compatibility/Segregation}

Waste compatibility/segregation requirements are common to both SSTs and DSTs and are detailed in Chapter 1.

\subsection{DSTs for Pretreated LLW}

Sufficient waste must be removed from the DST such that the soluble fraction and suspendable solids of the tank waste heel, when combined with pretreated LLW, result in a solution which complies with the constraints and performance requirements for Pretreated LLW for Immobilization (function 4.2.2.4).

Source: TWRS F\&R Performance Requirement - DSTs for Pretreated LLW

\subsubsection{System Capability Relationships}

\subsection{Definition of Operating Modes}

\subsection{Start-up/Testing}

Start-up and testing requirements are common to both SSTs and DSTs and are detailed in Chapter 1.

\subsection{Operations}




\section{Dome Loading}

The static dome loading shall not exceed the equivalent maximum depth of soil'above the tanks measured at the center (crown) of the tank dome and the live load shall not exceed the maximum value as described in the Table 3-2 below in order to prevent structural damage to tank domes.

Table 3-2. Maximum Soil Depth/Live Loads Above Tanks.

\begin{tabular}{|c|c|c|}
\hline 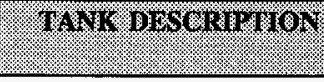 & 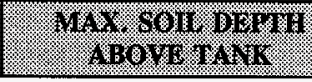 & 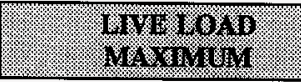 \\
\hline \multicolumn{3}{|c|}{ Double-Shell Waste Storage Tanks (241-AN, AP, AW, AY, AZ and SY Tank Farms) } \\
\hline AN, AP, AW & $7 \mathrm{ft}$. & $\begin{array}{l}40 \mathrm{lb} / \mathrm{ft}^{2} \text { uniform load, } \\
50 \text { tons concentrated load }\end{array}$ \\
\hline SY & $6.5 \mathrm{ft}$. & $\begin{array}{l}40 \mathrm{lb} / \mathrm{ft}^{2} \text { uniform load, } \\
50 \text { tons concentrated load }\end{array}$ \\
\hline
\end{tabular}

Source: $\quad$ OSD-T-151-00007, 7.2.4

\section{Emergency High-Level Waste Transfers}

For emergency situations involving liquid high-level waste, spare capacity with adequate heat dissipation capability shall be maintained to receive the largest volume of liquid contained in any one tank. Adequate transfer pipelines also shall be maintained in operational condition. Interconnected tank farms with adequate transfer capabilities and spare capacity may be considered as a single tank farm for purposes of this requirement.

Source: $\quad$ DOE5820.2A, Chapter I, 3.b(4)(d)

\subsection{Decontamination and Decommissioning}

Decommissioning and decontamination requirements are common to both SSTs and DSTs and are detailed in Chapter 1, Section 2.3.2.1.1 and 3.3.2.1.1.

\subsection{Operating Modes Schedule}

\subsection{DST Waste Retrieval Schedule}

TBD

Source: TWRS F\&R Performance Requirement - DST Waste Retrieval Schedule 
Issue: A schedule defining when DST waste needs to be retrieved has not been prepared to show how retrieval will support the disposal program needs. This schedule can be prepared either in conjunction with or subsequent to the Tank Waste Retrieval Schedule. This schedule will form a basis for the DST retrieval sequence and project definition.

Required Analysis: Develop a schedule showing when each type of DST waste (e.g., supernate and sludge) needs to be retrieved.

\subsection{Near-term DST Capital Funding}

Near-term fiscal year capital funding for DST retrieval shall be minimized and should not exceed the following guidance.

$\begin{array}{cccc}\begin{array}{c}\text { Fiscal } \\ \text { Year }\end{array} & \begin{array}{c}\text { Capital Funding } \\ \mathbf{( \$ M )}\end{array} & \begin{array}{c}\text { Fiscal } \\ \text { Year }\end{array} & \begin{array}{c}\text { Capital Funding } \\ \mathbf{( \$ M )}\end{array} \\ 1995 & 5 & 2001 & 12 \\ 1996 & 12 & 2002 & 18 \\ 1997 & 13 & 2003 & 18 \\ 1998 & 14 & 2004 & 18 \\ 1999 & 11 & 2005 & 18 \\ 2000 & 11 & & \end{array}$

Source: $\quad$ TWRS F\&R Performance Requirement - Near-term DST Capital Funding

Issue: The limits specified above are based on the target funding case for W-211, Initial DST Retrieval, through 2001 and an extrapolation for the subsequent years. A conservative projection of expected near-term capital funding for DST retrieval is needed to assure that the retrieval systems will be available when needed to support near-term safety issue resolution, startup of LLW waste pretreatment and immobilization, and initial SST waste retrieval.

Required Analysis: Develop a conservative projection of expected near-term capital funding scenario DST retrieval (i.e., through 2005).

\subsubsection{External Interface Requirements}

The majority of external interface requirements are common to both SSTs and DSTs and are detailed in Chapter 1. This Section provides those interface requirements which are specific to DSTs. 


\subsection{Input: DST Waste for Retrieval}

Wastes stored in underground DSTs that are to be retrieved for treatment, safety issue resolution, or disposal. This waste includes the supernate, saltcake, sludge, and in-tank hardware. In-tank hardware and discrete sources will be dispositioned by the Remediate Solid Waste function.

\subsection{Volume of DST Waste for Retrieval}

The volume of DST waste that will be retrieved for disposal is approximately 75,800 cubic meters (20 million gallons) of waste as presently stored in the DSTs. Transfer of liquids from the SSTs for concentration and storage in the DSTs may alter the volume of tank waste for retrieval.

\section{Source: WHC-EP-0182}

\subsection{Input: Tank Operations Information}

Retrieve waste requires tank operations information consisting of monitoring and surveillance data which includes: in-tank temperature measurements, pressure measurements, waste level measurements, photographs, emission monitoring data, data from specialty equipment, as well as information related to the structure of the tank and its safety status. Tank operations information is provided by the Store Managed Tank Waste (sub-function Manage System Information) function.

\subsection{Tank Operations Requirements}

\section{Cross-Site Transfer Tank Operations}

Information with respect to tank storage status, routing configurations, and other operational data required to perform cross-site transfers shall be provided for the purposes of operating the cross-site transfer system.

Source: $\quad$ TWRS F\&R Performance Requirement - Cross-site Transfer Tank Operations Information

\section{Transfer System Temperature Ranges Operations}

The waste storage facility shall transfer waste that does not exceed the temperature limits of at least $82.2^{\circ} \mathrm{C}\left(180^{\circ} \mathrm{F}\right)$ and up to $149^{\circ} \mathrm{C}\left(300^{\circ} \mathrm{F}\right)$.

The primary tank waste temperature limits for each tank are limited to prevent excessive stress to the primary tank and vary depending on the particular DST in question. 
Source: $\quad$ TWRS F\&R Performance Requirement - Transfer System Temperature Ranges Operations Information

\subsection{Input: Tank Waste Characterization Information}

Tank Waste Characterization Information consists of waste analysis data packages, waste in-situ measurement data, and other statistical data analysis.

Issue: Characterization performance requirements are not well defined at this time. The number and types of samples and analyses as well as the precision, accuracy, and schedule requirements need to be determined in order to provide characterization capacities and capabilities which are adequate to meet the needs.

Required Analysis: Develop data quality objectives (DQOs) for all TWRS programs needing characterization information. Questions to be addressed by the DQOs include, but are not limited to: What type of sample analyses will be required? How many sample analyses will be performed? Part of the scope of the Characterize Waste function is to develop these DQOs.

\subsection{Tank Characterization Requirements}

Waste sources shall transfer waste in accordance with the following matrix to the extent practicable. Source and receiving waste type shall be evaluated to ensure that tank waste types are compatible prior to initiating waste transfers.

Table 3-3. Tank Waste Type Matrix. (2 sheets)

\begin{tabular}{|c|c|c|c|c|c|c|c|c|c|}
\hline \multicolumn{2}{|c|}{$\begin{array}{l}\text { Sorroe Waste } \\
\text { mpe }\end{array}$} & \multicolumn{8}{|c|}{ 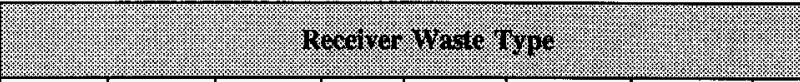 } \\
\hline & & DN & DSSF & DC & $\mathrm{CC}$ & (PD) & $\begin{array}{l}\text { NCRW } \\
\text { PT }\end{array}$ & NCAW & $\mathrm{CP}$ \\
\hline DN & $X$ & $\mathrm{X}$ & $\mathrm{X}$ & & $\mathrm{X}$ & & $X$ & $X$ & $\mathrm{X}$ \\
\hline DSSF & & $\mathrm{X}$ & & & & & & & \\
\hline$\overline{D C}$ & & & & & $\mathrm{X}$ & $\mathrm{X}^{1}$ & & & \\
\hline $\mathrm{CC}$ & & & & & $X^{1}$ & $\mathrm{X}$ & & & \\
\hline NCRW & $\mathrm{X}$ & & & & & $\mathrm{X}$ & & $\mathrm{X}$ & \\
\hline (PD) & & & & & & & & & \\
\hline PFP & $X$ & & & & & $X$ & & $X$ & \\
\hline (PT) & & & & & & & & & \\
\hline
\end{tabular}


Table 3-3. Tank Waste Type Matrix. (2 sheets)

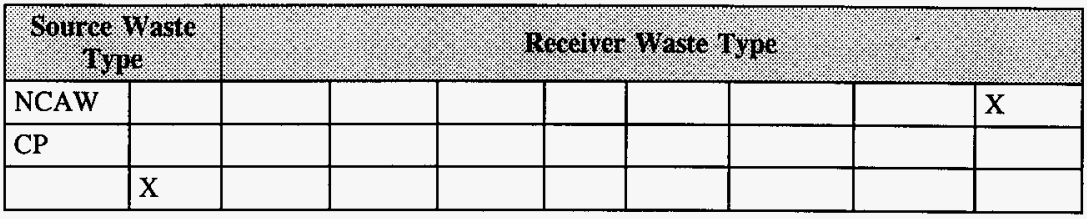

Notes:

$$
\begin{aligned}
& \text { DN = dilute non-complexant waste } \\
& \text { DSSF = double-shell slurry feed } \\
& \text { DC = dilute complexant waste } \\
& \text { CC = concentrated complexant waste } \\
& \text { PD = PUREX neutralized cladding. removal waste } \\
& \text { PT = TRU solids fraction from PFP Plant operations } \\
& \text { NCAW = Aging waste from PUREX } \\
& \text { CP = concentrated phosphate waste } \\
& \text { X = Indicated waste type mixing which has occurred historically without adverse effects. } \\
& \text { 'Adding CC to DC is permitted but would not ordinarily be done. The volume of combined } \\
& \text { waste which would need to be evaporated would be increased, resulting in increased } \\
& \text { evaporation costs. }
\end{aligned}
$$

Source: $\quad$ TWRS F\&R Performance Requirement - Tank Waste Type

\subsection{Output: Closure-Ready DSTs}

DSTs from which sufficient waste has been retrieved to meet closure requirements.

Issue: Uncertainty exists with respect to the programmatic responsibility for disposition (closure) of double-shell tank structures. May be closed by TWRS or Environmental Remediation (Site-level 4.4 function). Ref. Hanford Mission Plan.

Source: DOE5820.2A, Chapter I, 3.b(3)(c)

\subsubsection{Physical Characteristics}

The DST retrieval system will be located in the 200 area of the Hanford site. Details of the site boundary and land use restrictions are given in Chapter 1.

\subsubsection{System Quality Factors}

The requirements for the reliability, maintainability, availability, and other quality factors for the system are common to both SSTs and DSTs and are detailed in Chapter 1. 


\subsubsection{Environmental Conditions}

Environmental conditions for the Hanford site are given in Chapter 1.

\subsubsection{Transportability}

Reserved

\subsubsection{Flexibility and Expansion}

The requirements for the flexibility and expansion for the system are common to both SSTs and DSTs and are detailed in Chapter 1.

\subsubsection{Portability}

Reserved

\subsubsection{Design and Construction}

The design and construction requirements are common to both SSTs and DSTs and are detailed in Chapter 1.

\subsubsection{Documentation}

Documentation requirements are common to both SSTs and DSTs and are detailed in Chapter-1.

\subsubsection{Logistics}

Prior to tank transfer the receiving tank shall have sufficient capacity to receive waste from the DSTs.

\subsubsection{Personnel and Training}

Personnel and training requirements are common to both SSTs and DSTs and are detailed in Chapter 1.

\subsubsection{Characteristics of Sub-System Elements}

Figure 3-3 represents the DST Waste Retrieval Sub-System Elements. 
Figure 3-3. Double-Shell Tank Waste Retrieval Sub-System Elements.

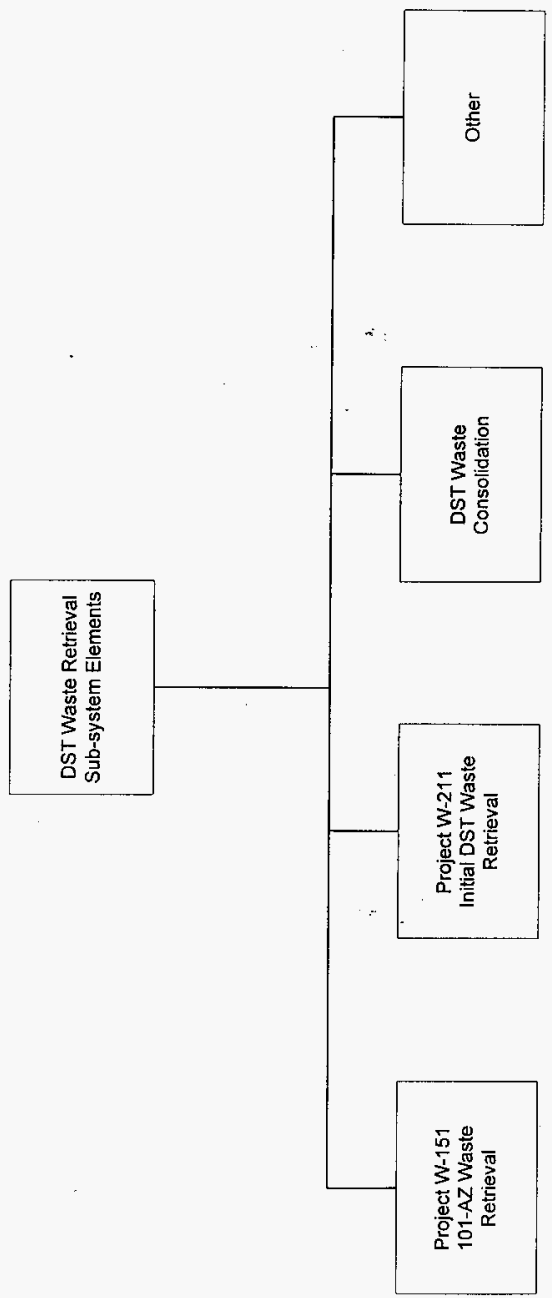




\subsubsection{Project W-151, 101-AZ Retrieval}

A process test will be performed in tank 241-AZ-101 to demonstrate the capability of mixer pumps to mobilize neutralized current acid waste sludge. Concurrent with this activity, advanced design mixer pumps (ADMPs) will be procured and tested with the goal of enhanced mobilization capability, improved reliability, and reduced life cycle costs. Performance data obtained in ADMP testing will be applied to the specification for equipment to be procured and installed by Project W-211.

Source: $\quad$ TWRS F\&R Performance Requirement - DST Waste Retrieval Demonstration Tank Selection

\subsubsection{Project W-211, Initial DST Waste Retrieval}

Project W-211 will provide mixer pump based retrieval systems for ten (10) DSTs. Project W-211 will initiate Title II design on the first retrieval system.

\subsubsection{DST Waste Consolidation}

Consolidation of compatible DST wastes must be conducted to maximize the available DST space to support tank waste management activities (Manage Tank Waste function), such as stabilization of SSTs and receipt of new tank wastes (Letter, J. E. Kinzer, RL, to President, WHC, "Multi-Function Waste Tank Facility - Project W-236A Decision Paper", \#95-TOP-027, dated March 17, 1995). Waste consolidation actions and schedule completion dates which must be achieved in order to ensure sufficient DST space is available are:

Consolidate 241-AZ-101 sludge in tank 241-AZ-102 (10/1996)

Consolidate 241-SY-102 sludge in tank 241-AW-103 (10/1998)

Consolidate 241-AW-105 sludge in tank 241-AW-103 (12/1999)

Consolidate 241-C-106 sludge in tank 241-AZ-102, via tanks 241-AY-102 and 241-AZ-101 (start by $10 / 1996$ ).

Source: Internal memo \#73510-95-017 DST Waste

\subsubsection{Other Projects}

Other projects necessary to complete double-shell tank waste removal and closure of the tanks have yet to be fully defined.

\subsubsection{Precedence}

The hierarchical relationships among the SST and DST requirements are common and are detailed in Chapter 1. 


\subsubsection{Qualification}

Reserved

3.3.10 Standard Sample

Reserved

\subsection{QUALITY ASSURANCE PROVISIONS}

Quality assurance provisions are common to both SSTs and DSTs and are detailed in Section 1.0.

\subsubsection{Responsibility for Inspections}

Responsibility for inspections are common to both SSTs and DSTs and are detailed in Section 1.0.

\subsubsection{Special Tests and Examinations}

Table 3-4 correlates the requirements of Section 3.3 with the method to be used to comply with the requirements. Documentation of compliance will be accomplished through the use of detailed procedures to be developed and performed on all procured, constructed, and developed equipment, structures, and software.

The methods of compliance to be used are:

A. Analysis. Analysis is the process needed to verify a requirement by rational thinking, tradeoff studies, modeling, and processing test data and accumulated results to reach a conclusion. Analysis involves the processing of accumulated results and conclusions, intended to provide proof that verification of a requirement has been accomplished. The analytical results may be comprised of a compilation or interpretation of existing information or derived from lower level examinations, tests, demonstrations, or analyses.

B. Examination. Examination is the process of investigating a product to verify that required features are incorporated. Examination consists of investigation, without the use of special laboratory appliances, procedures, supplies, or services, to determine conformance to those specified requirements which can be determined by such investigations. Examination is generally nondestructive and includes, but is not limited to, visual, auditory, olfactory, tactile, and other investigations; simple physical manipulation; gauging; and measurement.

C. Test. Test is the quantitative process whereby data is collected over a specified time period, under controlled conditions, in order to document the as-built performance of a product. A test denotes the determination of the properties or elements of items (or 
components thereof) by technical means, including functional operation, the application of established principles and procedures and the collection of quantitative data. The analysis of data derived from testing is an integral part of the method.

D. Demonstration. Demonstration is the qualitative process of exercising a product to verify its operability, where data may or may not be collected. Demonstration differs from test by directness of approach in the verification of a requirement and is accomplished without the use of instrumentation or special equipment. Thus, operation of a representative item in or near its use environment would be defined as a Demonstration rather than a Test.

Demonstration attempts to verify, qualitatively, the performance of a function, where as Test involves verifying performance within a specific range of measurement.

When more than one method of compliance is marked in Table 3-4, compliance must be verified by one or more of the methods marked.

Table 3-4. Verification Matrix. (3 sheets)

\begin{tabular}{|c|c|c|c|c|c|c|}
\hline $\begin{array}{l}\text { Section } 3.3 \\
\text { Paragrapl }\end{array}$ & . Tite & N/A & A. & (1) & T: & 1). \\
\hline 3.3.2.1 & Performance Characteristics & $\mathrm{X}$ & & & & \\
\hline 3.3.2.1.1 & $\begin{array}{l}\text { Allowable Heel Following Retrieval From } \\
\text { DSTs }\end{array}$ & & $\mathrm{X}$ & & & \\
\hline 3.3 .2 .1 .2 & Allowable Heel in DSTs For Re-Use & & $\mathrm{X}$ & & & \\
\hline 3.3 .2 .1 .3 & Allowable Sludge Heel in 241-SY-102 & & $\bar{X}$ & & & \\
\hline 3.3.2.1.4 & Retrieval Method Selection & & & & & $\mathrm{X}$ \\
\hline 3.3 .2 .1 .5 & Waste Minimization/Volume Reduction & & $\mathrm{X}$ & & & \\
\hline 3.3 .2 .1 .6 & Waste Segregation & & $\mathrm{X}$ & & $\mathrm{X}$ & \\
\hline 3.3.2.1.7 & DSTs For Pretreated LLW & & & $\mathrm{X}$ & & \\
\hline 3.3 .2 .2 & System Capability Relationships & $\mathrm{X}$ & & & & \\
\hline 3.3.2.2.1 & Definition of Operating Modes & $\mathrm{X}$ & & & & \\
\hline 3.3 .2 .2 .1 .1 & Start-up/Testing & & & & $\mathrm{X}$ & \\
\hline 3.3 .2 .2 .1 .2 & Operations & & & & $\mathrm{X}$ & \\
\hline 3.3 .2 .2 .1 .3 & Decontamination and Decommissioning & $\mathrm{X}$ & & & & \\
\hline 3.3 .2 .2 .2 & Operating Modes Schedule & & $\mathrm{X}$ & & & \\
\hline 3.3 .2 .2 .2 .1 & DST Waste Retrieval Schedule & & $\mathrm{X}$ & & & \\
\hline 3.3 .2 .2 .2 .2 & Near-Term DST Capital Funding & & $\mathrm{X}$ & & & \\
\hline 3.3 .2 .3 & External Interface Requirements & $\mathrm{X}$ & & & & \\
\hline 3.3.2.3.1 & DST Waste for Retrieval (Input) & & $\mathrm{X}$ & & & \\
\hline
\end{tabular}


Table 3-4. Verification Matrix. (3 sheets)

\begin{tabular}{|c|c|c|c|c|c|c|}
\hline $\begin{array}{l}\text { Section } 3.3 \\
\text { Iaragraph }\end{array}$ & 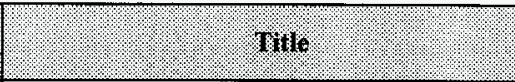 & NII & $i^{2}$ & E. & $1:$ & (1) \\
\hline 3.3.2.3.1.1 & Volume of DST Waste for Retrieval & & $\mathrm{X}$ & & & \\
\hline 3.3 .2 .3 .2 & Tank Operations Information (Input) & & $\mathrm{X}$ & & $\mathrm{X}$ & \\
\hline 3.3.2.3.2.1 & Tank Operations Requirements (Input) & & $\mathrm{X}$ & & $\mathrm{X}$ & \\
\hline 3.3 .2 .3 .3 & $\begin{array}{l}\begin{array}{l}\text { Tank Waste Characterization Information } \\
\text { (Input) }\end{array} \\
\end{array}$ & & $\bar{X}$ & & $\mathrm{X}$ & \\
\hline 3.3.2.3.3.1 & Tank Characterization Requirements & & & & $\mathrm{X}$ & \\
\hline 3.3 .2 .3 .4 & Closure Ready DSTs (Output) & & $\mathrm{X}$ & & & \\
\hline 3.3 .2 .4 & Physical Characteristics & $\mathrm{X}$ & & & & \\
\hline 3.3 .2 .5 & System Quality Factors & $\mathrm{X}$ & & & & \\
\hline 3.3 .2 .6 & Environmental Conditions & $\mathrm{X}$ & & & & \\
\hline 3.3 .2 .7 & Transportability & $\mathrm{X}$ & & & & \\
\hline 3.3 .2 .8 & Flexibility and Expansion & & & & $\mathrm{X}$ & $\mathrm{X}$ \\
\hline 3.3 .2 .9 & Portability (Reserved) & $\mathrm{X}$ & & & & \\
\hline 3.3 .3 & Design and Construction & & & & & $\mathrm{X}$ \\
\hline 3.3 .4 & Documentation & & $\mathrm{X}$ & & & \\
\hline 3.3 .5 & Logistics & & $\mathrm{X}$ & $\mathrm{X}$ & & \\
\hline 3.3 .6 & Personnel and Training & & $\mathrm{X}$ & & & \\
\hline 3.3 .7 & Characteristics of Sub-System Elements & $\mathrm{X}$ & & & & \\
\hline 3.3 .7 .1 & Project W-151, 101-AZ Retrieval & & & & $X$ & $\mathrm{X}$ \\
\hline 3.3 .7 .2 & Project W-211, Initial DST Waste Retrieval & & & & $\mathrm{X}$ & $\mathrm{X}$ \\
\hline 3.3 .7 .3 & DST Waste Consolidation & $\mathrm{X}$ & & & & \\
\hline 3.3 .7 .4 & Other Projects & & & & & $\mathrm{X}$ \\
\hline 3.3 .8 & Precedence & $\mathrm{X}$ & & & & \\
\hline 3.3 .9 & Qualification & & & & & $\mathrm{X}$ \\
\hline 3.3 .10 & Standard Sample & & & & & $\mathrm{X}$ \\
\hline 3.4 & Quality Assurance Provisions & & $\mathrm{X}$ & & & \\
\hline 3.4 .1 & Responsibility For Inspections & & $\mathrm{X}$ & & & \\
\hline 3.4 .2 & Special Tests and Examinations & $\mathrm{X}$ & & & & \\
\hline
\end{tabular}


Table 3-4. Verification Matrix. (3 sheets)

\begin{tabular}{|c|c|c|c|c|c|c|}
\hline 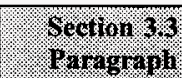 & 10 & W & . & (2) & 1 & 1 \\
\hline 3.4 .3 & Requirements Cross Reference & $\mathrm{X}$ & & & & \\
\hline 3.5 & $\begin{array}{l}\text { Preparation for Delivery (or Operations) } \\
\text { (Reserved) }\end{array}$ & $\mathrm{X}$ & & & & \\
\hline 3.6 & Notes (Reserved) & $\mathrm{X}$ & & & & \\
\hline
\end{tabular}

Notes:

$$
\begin{aligned}
& \text { N/A }=\text { Not applicable } \\
& A=\text { Analysis } \\
& E=\text { Examination } \\
& T=\text { Testing } \\
& D=\text { Demonstration }
\end{aligned}
$$

\subsubsection{Requirements Cross Reference}

\begin{tabular}{|c|c|c|}
\hline 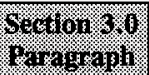 & 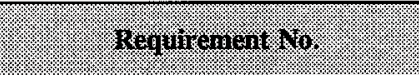 & 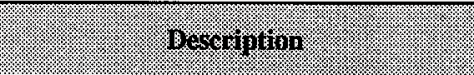 \\
\hline \multicolumn{3}{|c|}{ Performance Requirements } \\
\hline 3.3 .2 .1 .1 & HDW-EIS, Vol.2,B.6 & $\begin{array}{l}\text { Allowable Heel following retrieval from } \\
\text { DSTs }\end{array}$ \\
\hline 3.3 .2 .1 .1 & POCH.A.3.DST & $\begin{array}{l}\text { Allowable Heel following retrieval from } \\
\text { DSTs }\end{array}$ \\
\hline 3.3 .2 .1 .2 & WHC-SD-WM-TA-162 & Allowable Heel in DSTs for Re-Use \\
\hline 3.3 .2 .1 .3 & Internal Memo \#73510-95-017 & Allowable Sludge Heel in 241-SY-102 \\
\hline 3.3 .2 .2 .1 .2 & DOE.5820.2A,Chapter I, 3.b(4)(d) & $\begin{array}{l}\text { Spare capacity with adequate heat } \\
\text { dissipation capabilities }\end{array}$ \\
\hline 3.3 .7 .3 & Internal Memo \#73510-95-017 & DST Waste Consolidation \\
\hline 3.3 .7 .1 & WHC-SD-WM-FRD-020 & $\begin{array}{l}\text { DST Waste Retrieval Demonstration - } \\
\text { Tank } 241-A Z-101 \text { to demonstrate the } \\
\text { capability of mixer pumps }\end{array}$ \\
\hline
\end{tabular}

See Table 3-5.

\subsection{PREPARATION FOR DELIVERY (OR OPERATIONS)}

Reserved

Table 3-5. Requirements Traceability Matrix. (2 Sheets) 
Table 3-5. Requirements Traceability Matrix. (2 Sheets)

\begin{tabular}{|c|c|c|}
\hline 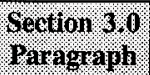 & Reguirement ro. & Besquilon \\
\hline 3.3 .2 .2 .2 .1 & WHC-SD-WM-FRD-020 & DST Waste Retrieval Schedule \\
\hline 3.3 .2 .1 .7 & WHC-SD-WM-FRD-020 & DSTs for Pretreated LLW \\
\hline 3.3 .2 .2 .2 .2 & WHC-SD-WM-FRD-020 & Near-term DST Capital Funding \\
\hline 3.3 .2 .2 .1 .2 & OSD-T-151-00007, 7.2 .4 & Dome loading \\
\hline 3.3 .2 .2 .1 .2 & OSD-T-151-00017, 17.2 .5 & Dome loading \\
\hline 3.3 .2 .3 .2 .1 & WHC-SD-WM-FRD-020 & $\begin{array}{l}\text { Cross-site transfer operations } \\
\text { information }\end{array}$ \\
\hline 3.3 .2 .3 .2 .1 & WHC-SD-WM-FRD-020 & $\begin{array}{l}\text { Transfer system Temperature ranges } \\
\text { operations information }\end{array}$ \\
\hline 3.3.2.3.3.1 & WHC-SD-WM-FRD-020 & Tank Waste type \\
\hline 3.3 .2 .1 .4 & WHC-SD-WM-FRD-020 & Select Retrieval Method \\
\hline 3.3 .2 .3 .1 .1 & WHC-EP-0182 & Volume of DST Waste for Retrieval \\
\hline \multicolumn{3}{|c|}{ Input/Output } \\
\hline 3.3 .2 .3 .1 & Input & DST Waste Retrieval \\
\hline 3.3 .2 .3 .2 & Input & Tank Operations Information \\
\hline 3.3.2.3.3. & Input & $\begin{array}{l}\text { Tank Waste Characterization } \\
\text { Information }\end{array}$ \\
\hline 3.3 .2 .3 .4 & Output & Closure-Ready DSTs \\
\hline
\end{tabular}




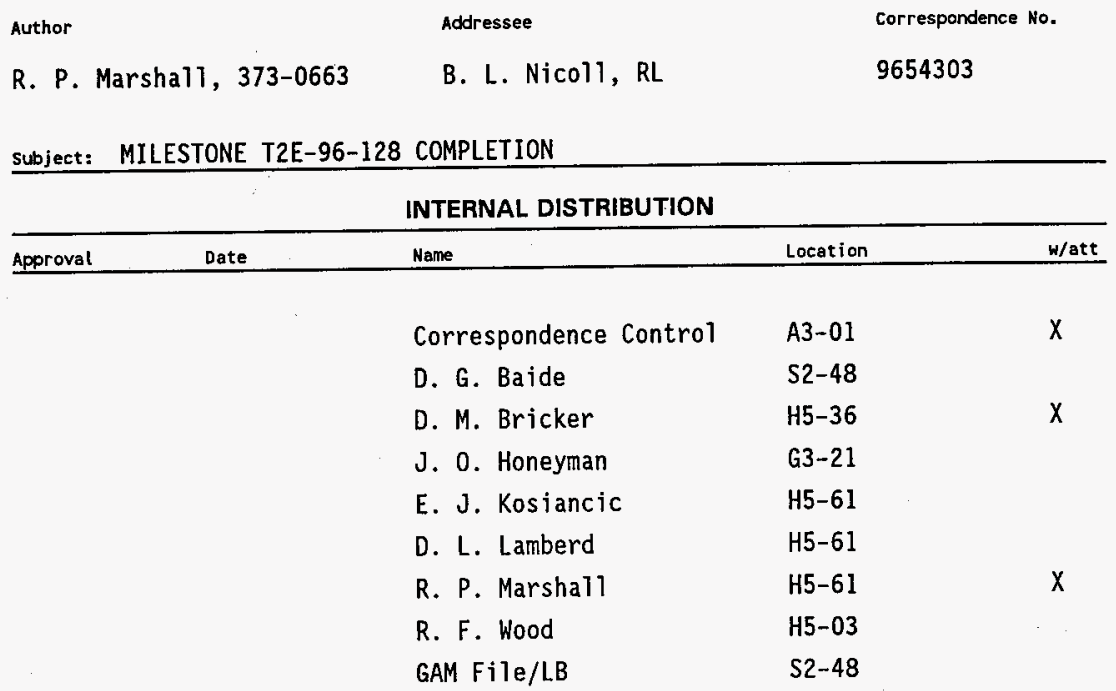

